\title{
WestVirginiaUniversity
}

THE RESEARCH REPOSITORY @ WVU

Graduate Theses, Dissertations, and Problem Reports

2007

\section{Petrologic study of the Murrysville sandstone in southwestern Pennsylvania}

\author{
Melissa L. Sager \\ West Virginia University
}

Follow this and additional works at: https://researchrepository.wvu.edu/etd

\section{Recommended Citation}

Sager, Melissa L., "Petrologic study of the Murrysville sandstone in southwestern Pennsylvania" (2007). Graduate Theses, Dissertations, and Problem Reports. 2522.

https://researchrepository.wvu.edu/etd/2522

This Thesis is protected by copyright and/or related rights. It has been brought to you by the The Research Repository @ WVU with permission from the rights-holder(s). You are free to use this Thesis in any way that is permitted by the copyright and related rights legislation that applies to your use. For other uses you must obtain permission from the rights-holder(s) directly, unless additional rights are indicated by a Creative Commons license in the record and/ or on the work itself. This Thesis has been accepted for inclusion in WVU Graduate Theses, Dissertations, and Problem Reports collection by an authorized administrator of The Research Repository @ WVU. For more information, please contact researchrepository@mail.wvu.edu. 


\title{
Petrologic study of the Murrysville sandstone in Southwestern Pennsylvania
}

\author{
Melissa L. Sager
}

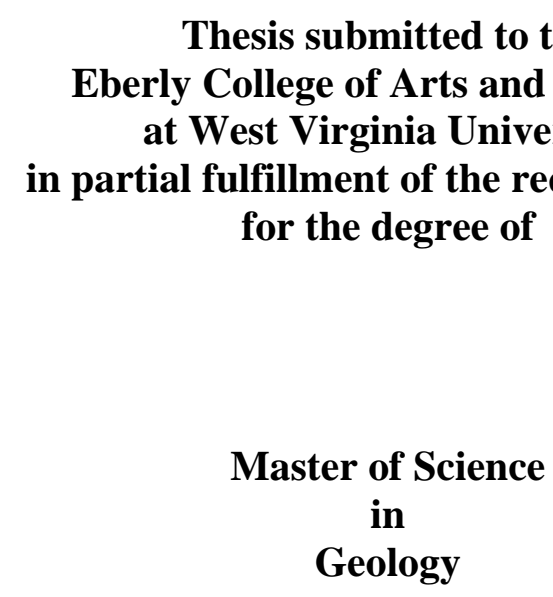

Richard Smosna, Ph.D., Chair Helen Lang, Ph.D.

Kathy Bruner, Ph.D.

Department of Geology and Geography

Morgantown, West Virginia 2007

Keywords: Murrysville, Cussewago, Berea, Southwestern Pennsylvania, Chlorite rims 


\begin{abstract}
Petrologic study of the Murrysville sandstone in southwestern Pennsylvania
\end{abstract} Melissa L. Sager

Pennsylvania’s Murrysville sandstone has been a proven gas producer since 1859 and a gas storage field since 1951. Using 49 side-wall cores from a gas well drilled in Westmoreland County, depositional environment and diagenesis are examined. In thin section, 5 microfacies are recognized. The lower two-thirds of the Murrysville is equivalent to the Cussewago of northwestern Pennsylvania and is interpreted as fluvial deltaic. The upper third is equivalent to the Berea of Ohio and is interpreted as being a marine transitional stream deposit.

Compaction was not extensive due to low amounts of ductile grains, rigid grain stability and matrix occupying space between grains. Chlorite cement, most commonly in the form of radiating needles, inhibited other cements and preserved primary porosity. Quartz cement, calcite cement and siderite cement are also present, quartz being the most abundant cement. Secondary porosity is present as moldic and intragranular porosity. Feldspars and rock fragments were most commonly leached. Permeability values ranged from 0.005 to nearly 1000 millidarcies. 


\section{ACKNOWLEDGMENTS}

The completion of this thesis would not have been possible without the support of some very important people. First I must express my utmost gratitude and respect to my advisor Dr. Richard Smosna. His guidance, knowledge and assistance through this process were invaluable. I also thank Dr. Helen Lang and Dr. Kathy Bruner for their time and guidance.

I thank Dominion Exploration and Production for providing me with the data for this project. I send special thanks to Richard Goings, Craig Edmonds and my coworkers for their support, encouragement and for allowing me the time and resources to complete this project. I send gratitude to Roy Lynch for his help arranging for the cores to be taken.

I thank Bret McDaniel for proposing this idea to me. His mentoring, direction and friendship from the beginning will follow me throughout my career. I also thank the West Virginia Geological and Economic Survey, especially Ron McDowell, for the use of their microscope to take photomicrographs.

I am very fortunate to have a wonderful foundation in my friends and family. My mother and father, who have always believed in me and have set a wonderful example for me in life. Your love for one another, your faith and your character have been an unspoken lesson in my life. To my husband Philip I thank you for your love, patience and understanding. With you by my side insurmountable tasks seem possible. Thank you for believing in me. 
ACKNOWLEDGMENTS ......................................................................................iii

LIST OF FIGURES ........................................................................................................vi

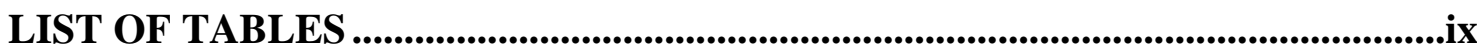

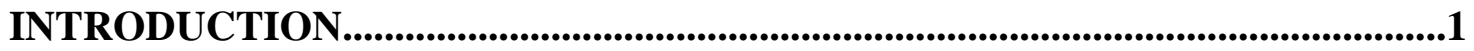

GEOLOGICAL SETTING ......................................................................................

Murrysville sandstone .................................................................................11

Cussewago Sandstone ......................................................................................12

Berea Sandstone ...............................................................................................................13

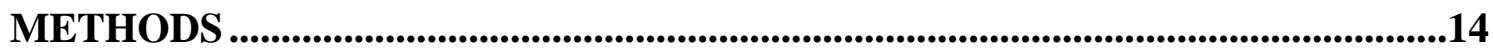

PETROGRAPHY ...............................................................................................................16

\section{MICROFACIES}

Quartzarenite ........................................................................................................28

Sublitharenite ........................................................................................................35

Conglomerate ...........................................................................................................37

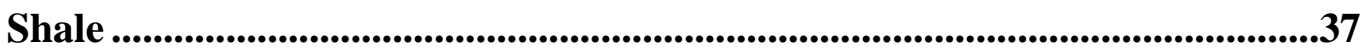

\section{DEPOSITIONAL HISTORY}

Cussewago $=$ Lower Murrysville .............................................................................40

Berea $=$ Upper Murrysville .....................................................................................43

Sedimentary Environment at Snyder Location ..................................................44

\section{DIAGENETIC PROCESSES}

Compaction...........................................................................................................50

Cementation........................................................................................................55

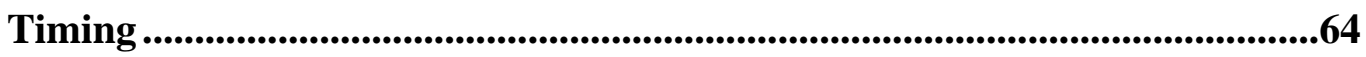

\section{DIAGENESIS - POROSITY DEVELOPMENT}

Primary Porosity ............................................................................................................67

Secondary Porosity …………………….....................................................................72

Permeability...................................................................................................................73 


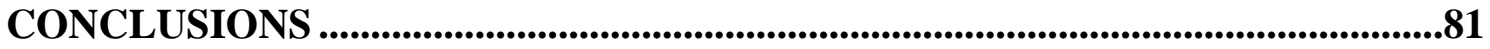

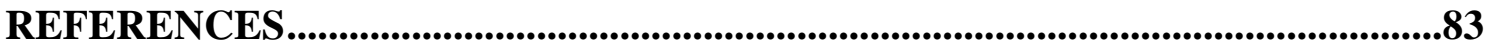

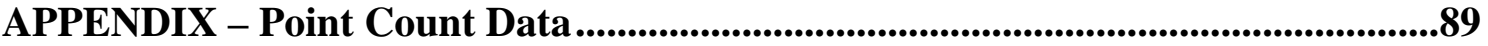




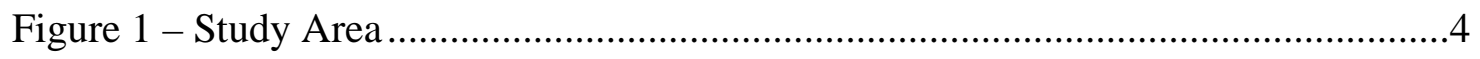

Figure 2 - Stratigraphic column .........................................................................6

Figure 3 - Position of Upper Devonian shoreline ……..................................................8

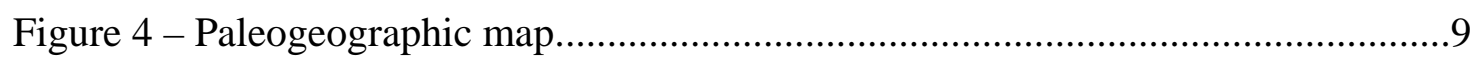

Figure 5 - Stratigraphic relationships and sea level change ..........................................10

Figure 6 - Sea-level curve and sea level change …………...........................................10

Figure 7 - Geophysical log showing core points.........................................................15

Figure 8 - Photomicrograph of Quartz in plane polarized and cross polarized light ......17

Figure 9 - Photomicrograph of Phyllite rock fragment..................................................19

Figure 10 - Photomicrograph of Volcanic rock fragment ...............................................19

Figure 11 - Photomicrograph of Chamosite in plane and cross polarized light...............21

Figure 12 - Photomicrograph of Pyrite and Zircon .......................................................22

Figure 13 - Photomicrograph of Matrix of quartz silt ..................................................22

Figure 14 - Photomicrograph of Quartz Cement on chlorite rims ..................................24

Figure 15 - Photomicrograph of Chlorite Cement as needle-like rims ...........................22

Figure 16 - Photomicrograph of Chlorite Cement precipitated in fan shape ..................25

Figure 17 - Photomicrograph of Calcite Cement ..........................................................27

Figure 18 - QFL Diagram...................................................................................29

Figure 19 - Stratigraphic column showing microfacies ...................................................30

Figure 20 - Graph of Quartz grains vs Depth.................................................................31

Figure 21 - Graph of Phyllite Rock Fragments vs Depth.................................................31

Figure 22 - Quartzarenite with loose packing ...................................................................33 
Figure 23 - Photomicrograph of Quartz with inclusions of mica................................33

Figure 24 - Photomicrograph of Plagioclase feldspar with preferential dissolution.......34

Figure 25 - Photomicrograph of Sublitharenite A....................................................36

Figure 26 - Photomicrograph of Fractured feldspar in cross polarized light ..................36

Figure 27 - Photomicrograph of Conglomeratic polycrystalline grain .........................38

Figure 28 - Photomicrograph of Shale in plane and cross polarized light ....................39

Figure 29 - Measured Murrysville section ..........................................................41

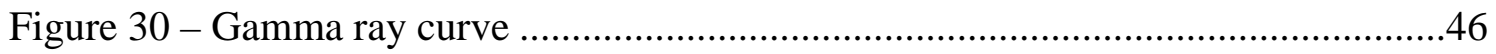

Figure 31 - Paleogeographic map during Murrysville Time.....................................47

Figure 32 - Graph of Mean Grain Size vs Depth ..................................................48

Figure 33 - Graph of Compaction Index vs Primary Porosity ....................................53

Figure 34 - Graph of Compaction Index vs Grain Size.............................................53

Figure 35 - Graph of Compaction Index vs Matrix...............................................54

Figure 36 - Graph of Quartz Cement vs Depth .....................................................56

Figure 37 - Graph of Chlorite Rims vs Quartz Cement ............................................58

Figure 38 - Graph of Chlorite Rims vs Depth ......................................................60

Figure 39 - Graph of Calcite Cement vs Depth......................................................63

Figure 40 - Photomicrograph of Calcite Cement fills Moldic Pore .............................63

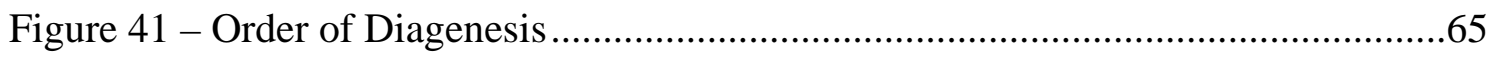

Figure 42 - Graph of Quartz and Calcite Cement vs Depth ......................................70

Figure 43 - Graph of Primary Porosity vs Quartz Cement..........................................70

Figure 44 - Graph of Compaction vs Primary Porosity .........................................71

Figure 45 - Graph of Primary Porosity vs Chlorite Coatings......................................71 
Figure 46 - Photomicrograph of Moldic Pore with chlorite rim .................................75

Figure 47 - Photomicrograph of Intragranular pore coated with chlorite needles ..........76

Figure 48 - Graph of Phyllite vs Secondary Porosity................................................77

Figure 49 - Graph of Secondary Porosity vs Depth ..............................................77

Figure 50 - Graph of Total Porosity vs Depth.......................................................78

Figure 51 - Figure Comparing gamma ray, density, porosities and microfacies ...........79

Figure 52 - Graph of Permeability vs Depth ........................................................

Figure 53 - Graph of Porosity vs Permeability .....................................................81 


\section{LIST OF TABLES}

Table 1 - Point count data for 4 microfacies ........................................................32 


\section{INTRODUCTION}

The scope of this project is to look at the petrology of the Murrysville Sandstone in southwestern Pennsylvania. Understanding the petrology of this formation will allow for better production of gas in this reservoir. The Murrysville is driller's nomenclature for the formation correlative to the Berea Sandstone, Bedford Shale, and Cussewago Sandstone. Only recognized as the Murrysville in southwestern Pennsylvania, here formation is a massive sandstone unit. Dominion Exploration and Production drilled a development well in Westmoreland County and took sidewall cores from the Murrysville before pursuing the deeper targets. These sidewall cores were cut into thin sections and were analyzed for this project. The analysis included minerals present, porosity, compaction, cement, order of diagenesis and interpretation of depositional environment.

Drilling for natural gas in southwestern Pennsylvania began in 1859, in which Mississippian and Devonian sandstone reservoirs were the primary targets. The wells were drilled using cable-tool drilling rigs, completed in an open hole, and produced naturally without fracture stimulation. In 1878 the Haymaker well was drilled in Westmoreland County, the well was the largest gas well ever drilled in the world up to that time, producing 34 million cubic feet of gas per day from the Murrysville sandstone (Harper and Laughrey, 1989). The Murrysville is an informal driller term for a sandstone in southwestern Pennsylvania that is equivalent to the Berea Sandstone, Bedford Shale and Cussewago Sandstone. Subsequent to the Haymaker, many wells targeted the Mississippian-Devonian Murrysville sandstone exclusively. Tomastik (1996) reported that in the Appalachian basin 221 fields have been developed in the Murrysville and equivalent reservoirs, including the Berea, Second Berea, and Cussewago. Of the 15,834 
wells drilled in these fields, gas was produced from 5,036 wells. Total cumulative production for these wells through 1992 was 600 billion cubic feet (bcf) (Tomastik, 1996). One well, drilled by Peoples Natural Gas in 1953 and located 12 miles (19.3 km) to the southwest of my study area, has produced 583 million cubic feet (MMcf) of gas from the Murrysville. The reservoir is estimated to have additional reserves of 160 MMcf of gas, for an estimated ultimate reserve of 750 MMcf.

Many drilling operations today, however, target deeper Devonian sandstones, overlooking the Murrysville sandstone. In recent years Dominion Exploration and Production has recognized the petroleum potential of this sandstone in southwestern Pennsylvania and is actively developing the gas resource. To obtain the best exploration results the formation needs to be better understood at the reservoir level.

In Westmoreland County, Pennsylvania, the 70 foot thick Murrysville in the Oakford field (Figure 1) was converted into a storage field in 1951. In this area the Murrysville is very porous, with porosity values as high as 18 percent, making it ideal for a gas storage field. The purpose of this study is to provide a detailed petrologic analysis of the Murrysville sandstone and its porosity in the Snyder \#3 well located southwest of the Oakford storage field. Thin-section description of side-wall cores includes rock type, mineral content, texture, matrix, pore type and pore volume. Petrographic description, in turn, allows for diagenetic interpretation and an understanding of porosity development, including compaction, cementation, and dissolution. Results of this study should provide insights to companies targeting and stimulating the formation. In a similar study, Stoneciper (2000) showed how important understanding the sandstone petrography is to 
stimulating the formation. Clays, cements and grains all behave differently to stimulation techniques and finding the right match is important for a successful well. 


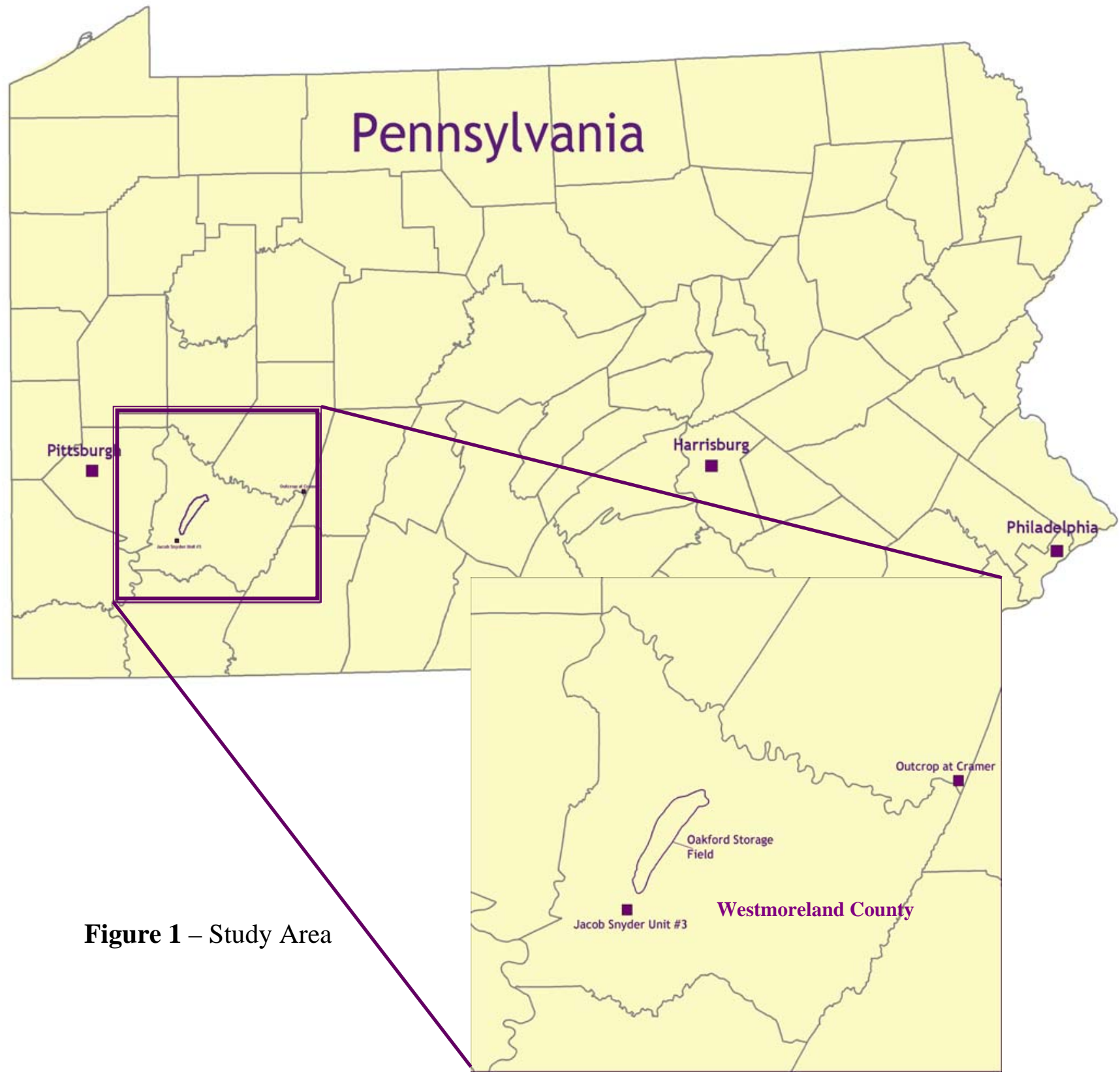




\section{GEOLOGICAL SETTING}

Petroleum production in southwestern Pennsylvania comes primarily from reservoirs of Mississippian and Devonian age. The Lower Mississippian section that lies above the Murrysville (Figure 2) consists of approximately 450 feet (135 m) of sandstone, siltstone, limestone and shale (Harper and Laughrey, 1989). The major formations include the Riddlesburg Formation, Cuyahoga Formation, Shenango Formation and Burgoon Formation. All of these units have had some petroleum production (Figure 2). The Burgoon is one of the most prolific Mississippian gas producers in Pennsylvania (Harper and Laughrey, 1989).

The Upper Devonian section below the Murrysville consists of the Elk, Bradford, Venango and Riceville Formations (Harper and Laughrey, 1989). The first three are formations currently targeted for gas production in southwestern Pennsylvania. There are seven main reservoir zones in the Venango Group. In ascending order, these include the Elizabeth, Bayard, Fifth, Fourth, Gordon, Ninevah, and the Hundred-Foot (Harper and Laughrey, 1987). These names are drillers’ terms but are widely accepted by geologists. The thickness of the Venango Group is variable, ranging from less than 100 feet (30m) to 600 feet (180m) (Harper and Laughrey, 1987).

The Venango Group is part of the Catskill clastic wedge which was deposited in the mid-late Devonian in response to the Acadian orogeny (Boswell, 1996). The uplift of the Acadian Mountains to the southeast provided a source of sediment. The basin also experienced periods of subsidence through isostatic adjustment. Hence, the Acadian uplift produced the sediment source as well as the basin to receive the Catskill wedge (Ettensohn, 1985). The eroded sand consisted mostly of quartz, rock fragments, and 


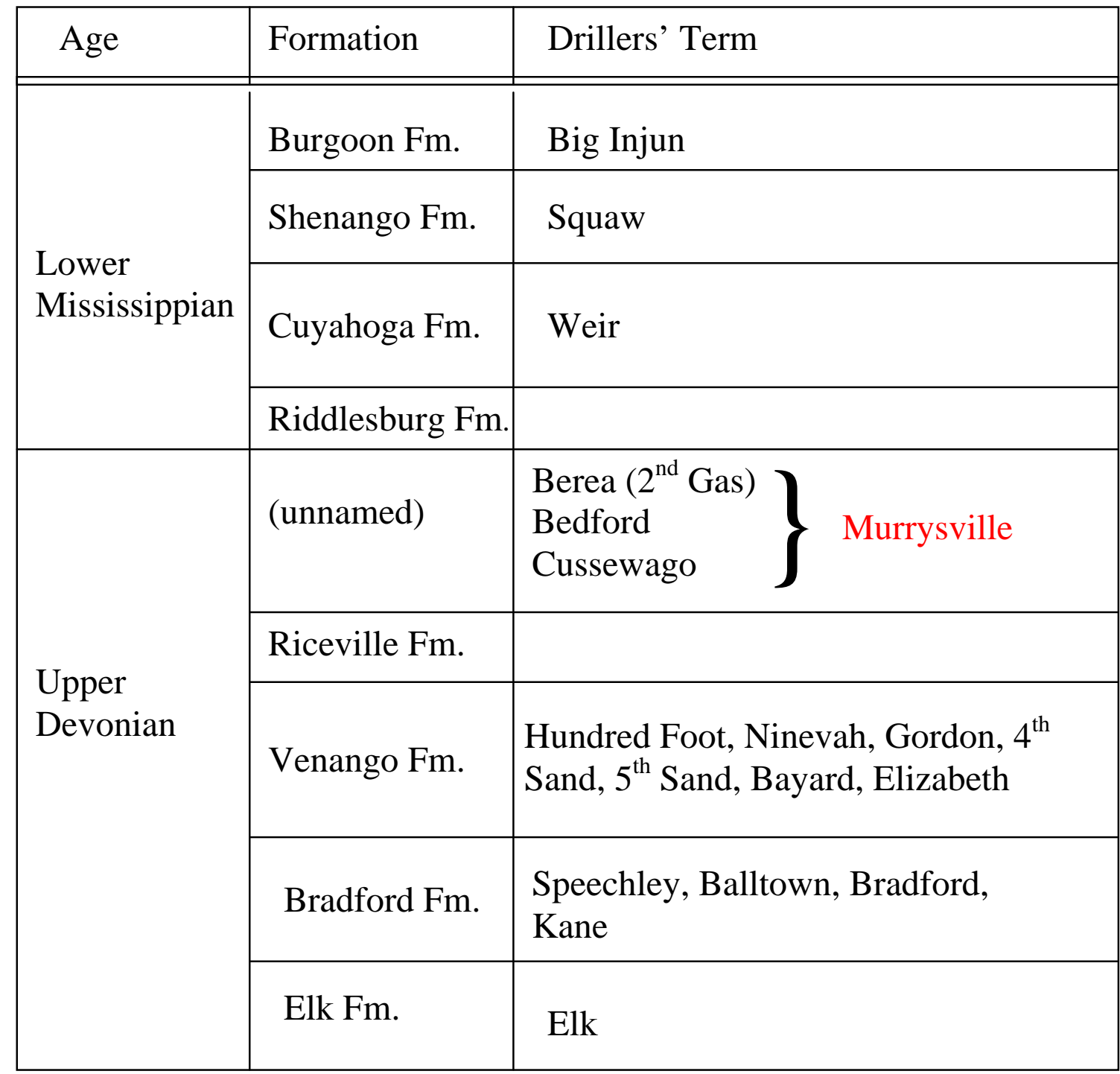

Figure 2 - Stratigraphic column showing Lower Mississippian and Upper Devonian reservoirs in southwestern Pennsylvania (from Harper and Laughrey, 1989). 
micas. Several minor transgressions occurred during this time, depositing marine muds and some carbonates across the western portion of the basin (Ettensohn, 1985). The delta complex prograded westward (Figure 3), and the basin filled with sediment by the end of the Devonian (Ettensohn, 1985; Harper \& Laughrey, 1989). Colton (1970) stated that as much as 80 percent of these Devonian sediments are the result of long-term cyclic storm patterns on the Catskill coastal plain.

Early Mississippian rocks were deposited in response to the last phase of the Acadian orogeny (Edmunds and others, 1979; Pashin \& Ettensohn, 1995; Vargo and Matchen, 1996). Sedimentation on the Catskill coastal plain had ceased, erosion on the alluvial plain nearest the Acadian Mountains provided sediment for the deltas growing to the west, and marine waters began to transgress across part of the alluvial plain (Sevon, 1985). Pepper and others (1954) recognized the development of several deltas at the western edge of the plain, including the Cussewago/Murrysville delta (Figure 4). Several fluctuations in sea level (Figure 5 and 6) influenced the depositional environments in Mississippian time. During a transgressive half cycle, deep-marine rocks were deposited, such as the black, organic-rich Riddlesburg Shale that overlies the Murrysville. In Ohio, western Pennsylvania, and western West Virginia, this unit is known as the Sunbury Shale (Harper and Laughrey, 1989). Mostly nonmarine deposition occurred during the subsequent regressive half cycle, and fluvial processes came to dominate the area. Over time the nature of the streams changed from meandering (represented by the Rockwell Formation in eastern Pennsylvania) to braided streams (Burgoon formation) (Harper and Laughrey, 1989). The Early Mississippian ended with formation of an erosional unconformity atop the Burgoon Formation. 


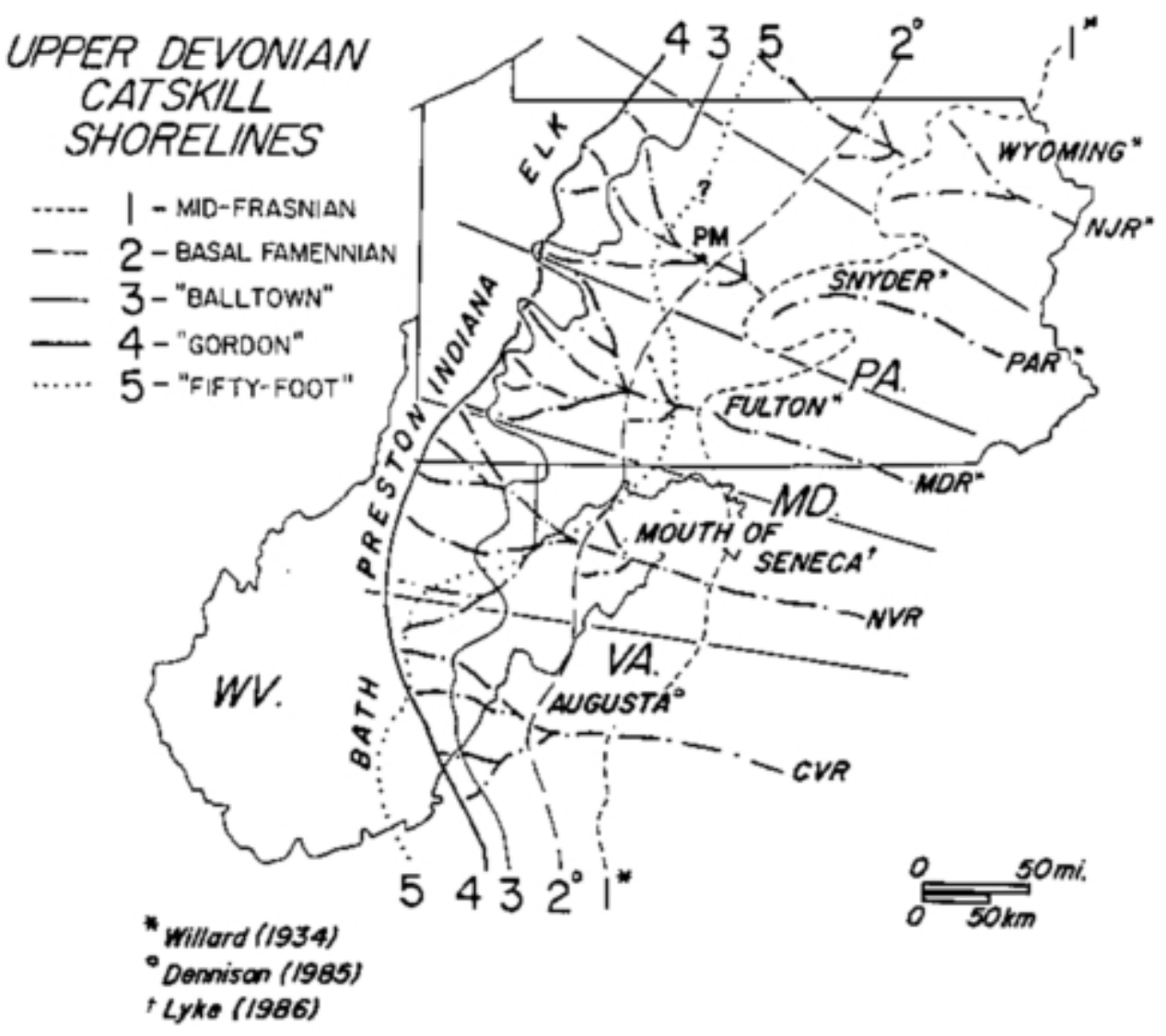

Figure 3 - Position of Upper Devonian shorelines of the Catskill delta complex (Boswell and Donaldson, 1988). 


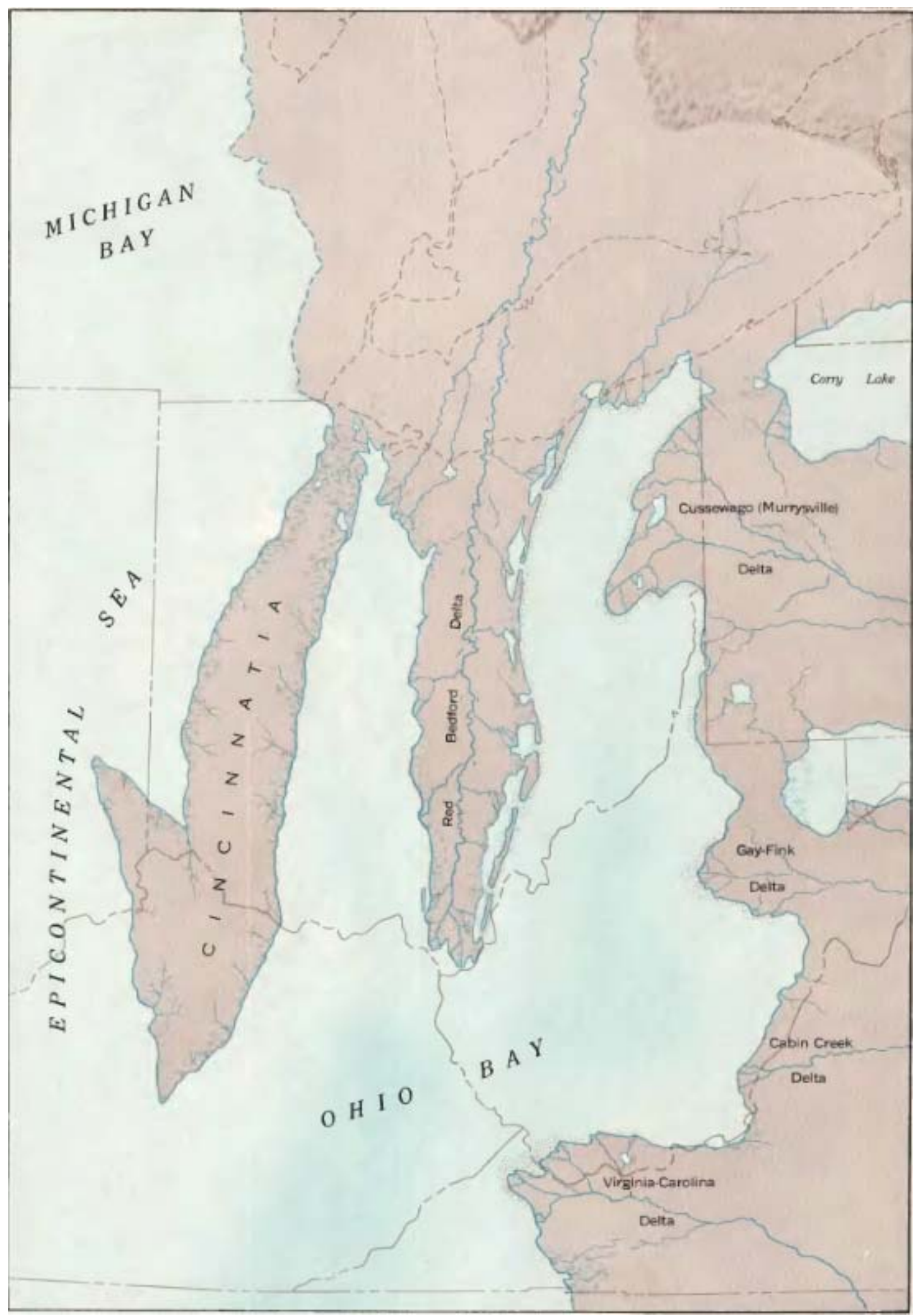

Figure 4 - Paleogeographic map from Pepper and others (1954) showing the various deltas in Late Devonian - Early Mississippian time. 


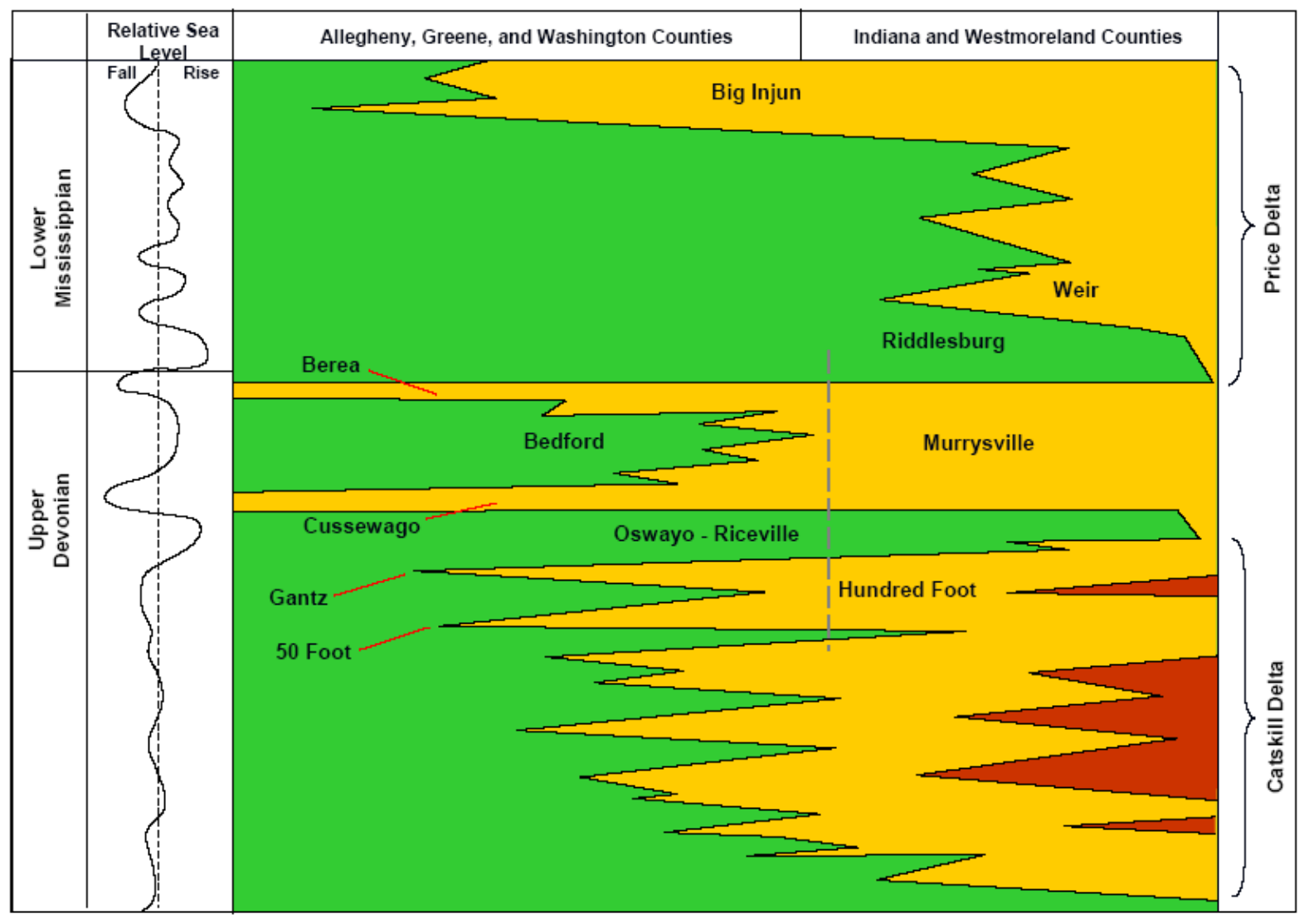

Figure 5 - Stratigraphic relationships and relative sea-level change in southwestern Pennsylvania. The gray dashed line indicates the approximate area where a change in drillers' nomenclature exists for the Murrysville and Hundred Foot in the east and their western equivalents. Yellow represents sandstone facies, green shows shale facies and red marks red beds. (Harper and Laughrey, 1989; McDaniel, 2006)

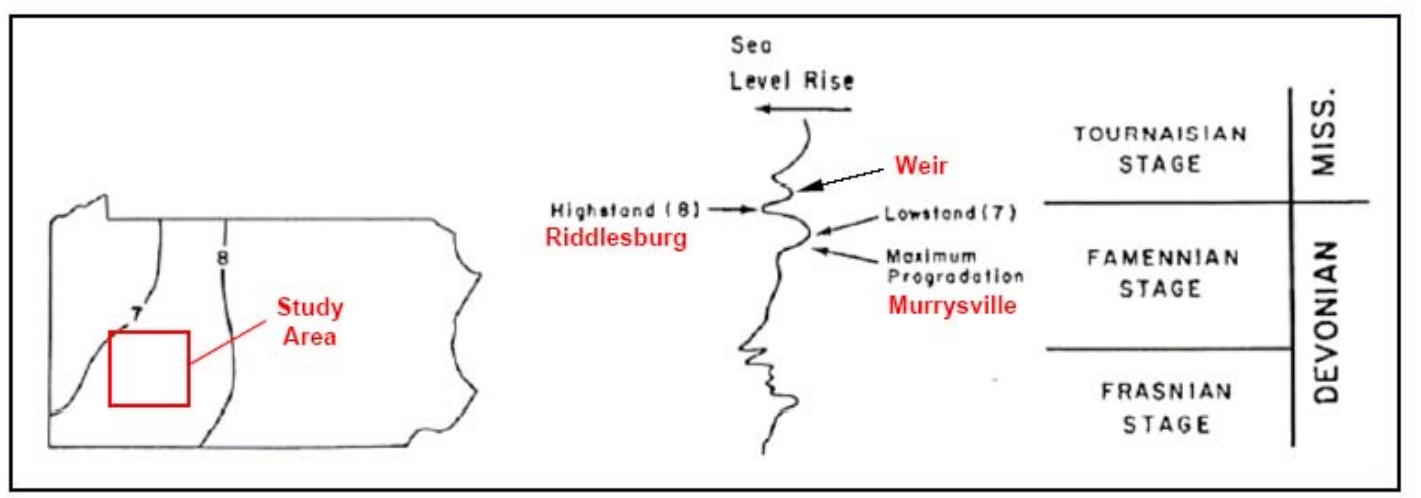

Figure 6 - Figure shows sea-level curve and shoreline position during the Upper Famennian and Lower Tournaisian in western Pennsylvania. Rapid sea level fall (7) led to the building of the Murrysville delta. A rise in sea level (8) lead to the deposition of the marine Riddlesburg Shale. (Dennison, 1985; McDaniel, 2006) 


\section{Murrysville sandstone}

In 1904 Butts informally named the producing unit in a prolific well outside of the town of Murrysville, Pennsylvania the Murrysville sandstone (Harper and Laughrey, 1989). Southwestern Pennsylvania is the only area where the sandstone is named Murrysville. It has also been called the Butler County Gas sandstone, Butler Gas sandstone, Butler Thirty-Foot sandstone, Gas sandstone, Great Pittsburgh Salt Water sandstone, and the Great Salt Water sandstone (Harper and Laughrey, 1989). An exact correlation of the Murrysville sandstone to other areas is unclear, although it has been correlated most frequently to the Berea and/or Cussewago Formation of northwestern Pennsylvania and Ohio. Pepper et al. (1954), for example, correlated the Murrysville to the Cussewago Sandstone of eastern Ohio. Some geologists, in turn, believed the Cussewago to be closely related to the Berea Sandstone, with the Bedford Shale being the break (Figure 2), calling it the Second Berea (Pashin \& Ettensohn, 1995).

More recently, Harper and Laughrey (1989) suggested that the lower portion of the Murrysville is equivalent to the Cussewago of northwestern Pennsylvania and the upper portion, to the Berea of Ohio (Figure 5). In some areas the unit is split by the Bedford Shale, in those areas the sandstone above the Bedford Shale is called Berea, and that below called Cussewago or Second Berea (Harper and Laughrey, 1989; Pashin and Ettensohn, 1995). In Westmoreland County, the site of my study, the Murrysville is a single sandstone with an average thickness of 60 feet (18.3 meters).

Paleontological work by Carter and Kammer (1990) suggests that the Cussewago is Late Devonian in age. DeWitt (1946) claimed that the Bedford Shale was deposited continuously across the time boundary making it both Upper Devonian and Lower 
Mississippian. Therefore, the Berea and equivalent sandstones would be Early Mississippian in age. Harper and Laughrey (1989) and Tomastik (1996) referred to the Murrysville as being Mississippian-Devonian because it correlates to both the Berea and Cussewago Sandstones. Pashin and Ettensohn (1995) agreed with Carter and Kammer, placing the Cussewago in the Upper Devonian based upon paleontological evidence. In this paper the Murrysville will be referred to as Upper Devonian to Lower Mississippian because of this fossil evidence reported from equivalent sandstones.

\section{Cussewago Sandstone of Pennsylvania}

White in 1881 named the Cussewago for exposures in northwestern Pennsylvania (McDaniel, 2006). In that region the Cussewago is a friable quartz sandstone that is green-yellow to green-brown in color. In Westmoreland County the Cussewago Sandstone in outcrop is fine- to coarse-grained, poorly cemented, and white, gray or greenish-yellow in color (Pepper et al. 1954; Harper and Laughrey, 1989). Its thickness ranges from 9 to 35 feet (2.7 to 10.7 meters) (Pepper et al., 1954). The Cussewago Sandstone is cemented by calcite, clay minerals and small amounts of quartz (Harper \& Laughrey, 1989).

Petroleum production in the Cussewago is uncertain because of its many aliases. Near Pittsburgh, salt water in the sandstone gave it the name Great Pittsburgh Salt Water sandstone. Because of the abundance of salt water, drillers commonly case through this sandstone. In Beaver County, to the north, the Cussewago produces gas and is sometimes called the Gas sandstone. It may also be equivalent to the Butler County sandstone. The Cussewago is often referred to as the Murrysville on drilling reports 
(Harper and Laughrey, 1989). With so many aliases it is possible that the Cussewago has produced more gas than what is generally thought (Harper and Laughrey, 1989).

\section{Berea Sandstone of Pennsylvania}

The Berea Sandstone was named by Newberry for exposures in Ohio (Pashin \& Ettensohn, 1995). The Berea is also known as grit because of the nature of the sandstone breaking into fine sand-sized pieces (Pepper et al., 1954). In Pennsylvania the Berea is commonly white to light-gray sandstone, a fine- to very fine-grained with occasional pockets of coarse sand and small pebbles (Harper and Laughrey, 1989; Tomastik, 1996). The thickness of the Berea Sandstone is variable, ranging from a few feet (less than a meter) to more than 235 feet (75 meters) (Pepper et al., 1954). Berea sand grains are commonly clay coated and are cemented with both calcite and quartz; quartz overgrowths are more abundant creating a low-porosity rock (Harper and Laughrey, 1989).

In northwestern Pennsylvania the Berea has a history of oil production and possibly gas production. Four main facies are present in the Berea play: shallow marine, fluvial-deltaic, barrier island, and fluvial (Tomastik, 1996), and petrophysical characteristics vary from facies to facies. Porosities determined from cores and well logs range from 2 to 26 percent with an average of 12 percent. Most of the porosity is primary intergranular, and secondary porosity has developed by dissolution of feldspar grains (Tomastik, 1996). 


\section{METHODS}

The Snyder Unit \#3 (API 37-129-25581), was drilled by Dominion Exploration and Production, Inc. in the fall of 2005. The well is located southwest of the Oakford gas storage field, in Westmoreland County, Pennsylvania. The well, located at $40^{\circ} 15^{\prime} 34^{\prime \prime}$ N and 7940'01', W, is 20 miles (32 kilometers) southeast of Pittsburgh, PA (Figure 1). This well did not produce gas from the Murrysville because the formation was downdip on the Grapeville anticline and had a high water content. Nevertheless, north of this well the Murrysville makes an excellent gas-storage field because of its thickness and high porosity.

The first step in this study was to obtain 49 side-wall cores (Figure 7) from the Murrysville. In the Snyder Unit \#3, the Murrysville is 77 feet thick (23.5 meters) and goes from 1846 to 1923 feet (563 to 586 meters). Once the formation was cored, the samples were sent to a commercial laboratory to have thin sections prepared. The 49 slides were stained with Alizaren red S so that calcite could easily be identified. The slides were also injected with a blue plastic to better observe porosity.

Microscopic analysis included a description of rock type, mineral content, texture, matrix, cement, authigenic minerals, and porosity. Three hundred points were counted on each slide using a grid system, with the exception of 2 small samples where 300 points could not be obtained (200 points were counted). The two shale samples were not point counted. Petrographic data from the point counts were placed into RockWorks software program to make a ternary diagram to identify lithofacies. All point count data are presented in appendix A. 


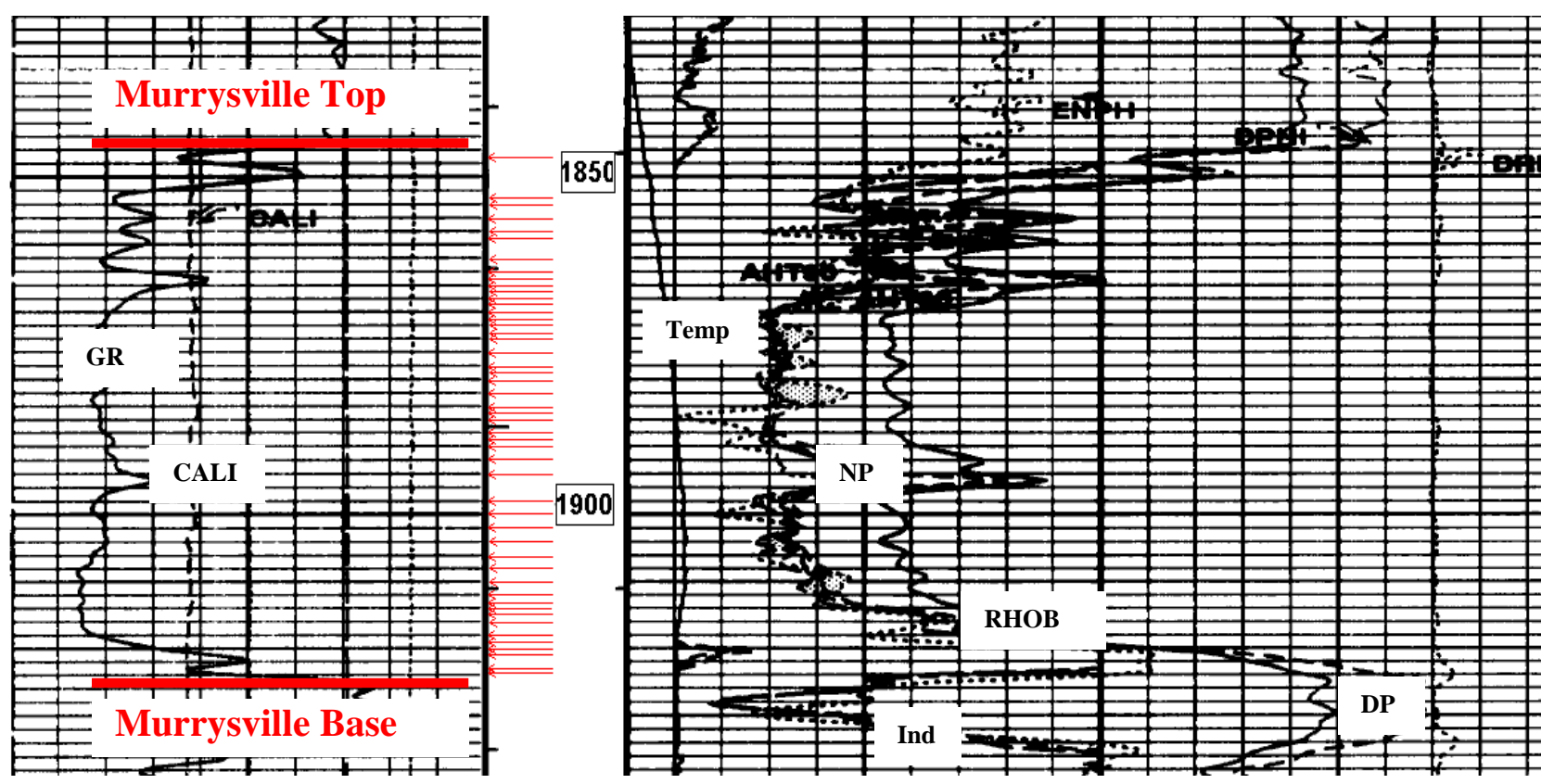

Figure 7 - Geophysical log (by Allegheny Wireline during drilling) showing Murrysville core samples marked in red. Depth (in black boxes) marked in feet. Logs shown include Gamma Ray (GR), Caliper (CALI), Temperature (Temp), Neutron Porosity (NP), Bulk Density (RHOB), Density Porosity (DP), and Induction (Ind). 


\section{PETROGRAPHY}

Only a few minerals are generally important rock formers in sandstones, and the abundance of these minerals depends on three factors: availability, mechanical stability and chemical stability. Quartz is the chief constituent of most sandstones because it is the most stable. Quartz can be detrital or authigenic, and authigenic quartz is commonly precipitated as quartz overgrowths. Other framework grains include chert, feldspar and rock fragments. These grains provide the framework of a sandstone. Additional constituents include accessory minerals, matrix and cements.

\section{Quartz}

Quartz is the dominant grain type throughout the Murrysville, ranging from 49-82 percent of total rock volume with a mean of 67 percent. The average grain size ranges from $0.250 \mathrm{~mm}$ to $0.500 \mathrm{~mm}$ (medium sand), but quartz silt and gravel are also present. Grains are mostly subrounded in shape. Many types of quartz are present including monocrystalline quartz, polycrystalline quartz, and undulose quartz (Figure 8). Some polycrystalline grains have elongated crystals; muscovite inclusions are common. Monocrystalline quartz, grains consisting of a single crystal, is thought to be plutonic in origin (Folk 1974). Undulose quartz, which goes to extinction at slightly different angles in crossed polarized light, may have originated by stress after solidification of the parent plutonic rock (Folk 1974). Polycrystalline quartz, comprised of composite crystals, which may or may not be elongate, are interpreted to be metamorphic in origin (Folk 1974). Quartz with inclusions of muscovite and are referred to as schistose metamorphic quartz after Folk (1974). 

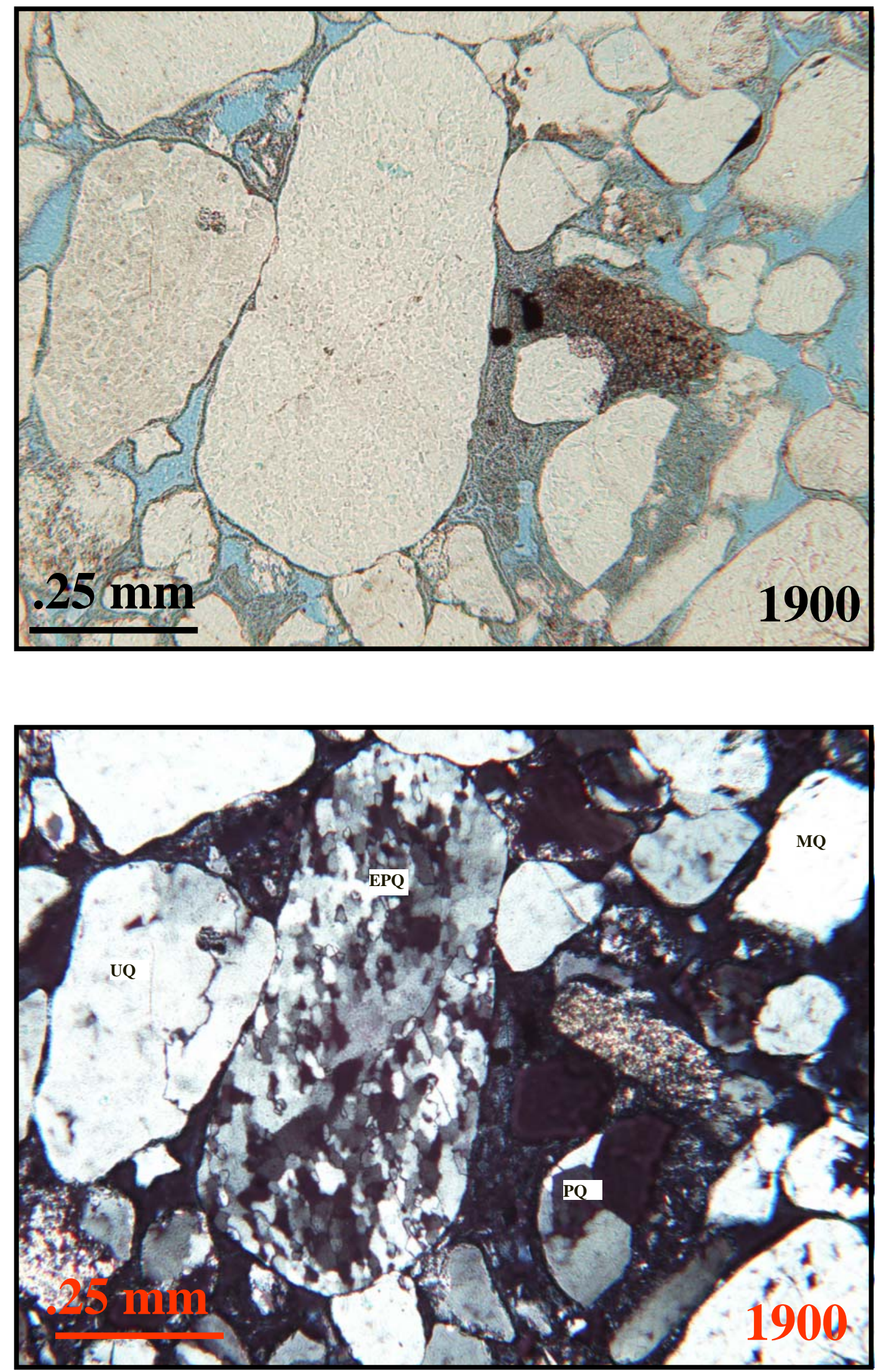

Figure 8 - Quartz in plane polarized light (top) and crossed polarized light (bottom) showing undulose quartz (UQ), monocrystalline quartz (MQ), polycrystalline quartz (PQ), and elongated polycrystalline quartz (EPQ). 


\section{Chert}

Detrital chert grains are scattered throughout the samples, comprising a maximum of 3 percent by volume. The grains are composed of microcrystalline quartz with small amounts of megaquartz (Folk, 1974).

\section{Phyllite Rock Fragments}

Phyllite rock fragments (Figure 9) which are medium sand size and average 0.350 $\mathrm{mm}$ in diameter are usually oval shaped, are common are most samples ranging from 4-9 percent. In samples where compaction has taken place, the fragments are bent and deformed around and between more competent grains. The clasts consist of sericite, a very finely crystalline mica, and fine quartz, and show a marked foliation. Other metamorphic grains, which are coarser grained and higher grade than phyllite, are pointcounted separately as schist. In these rock fragments the constituent crystals of muscovite are coarser and equant with high birefringence colors.

\section{Shale Rock Fragments}

Oval-shaped clasts of illite shale occur in many samples, ranging from 0-10 percent with a mean of 1 percent.

\section{Volcanic Rock Fragment}

One volcanic rock fragment (Figure 10) is present at 1919 feet (585 meters). The clast has a green chlorite matrix with euhedral phenocrysts of plagioclase feldspar.

\section{Feldspars}

Plagioclase, K-feldspar and microcline were observed in the Murrysville samples, but feldspars are rare making up less than 1 percent of the rock. Plagioclase is recognized by its albite twinning, K-feldspar by perthites and microcline by its tartan 


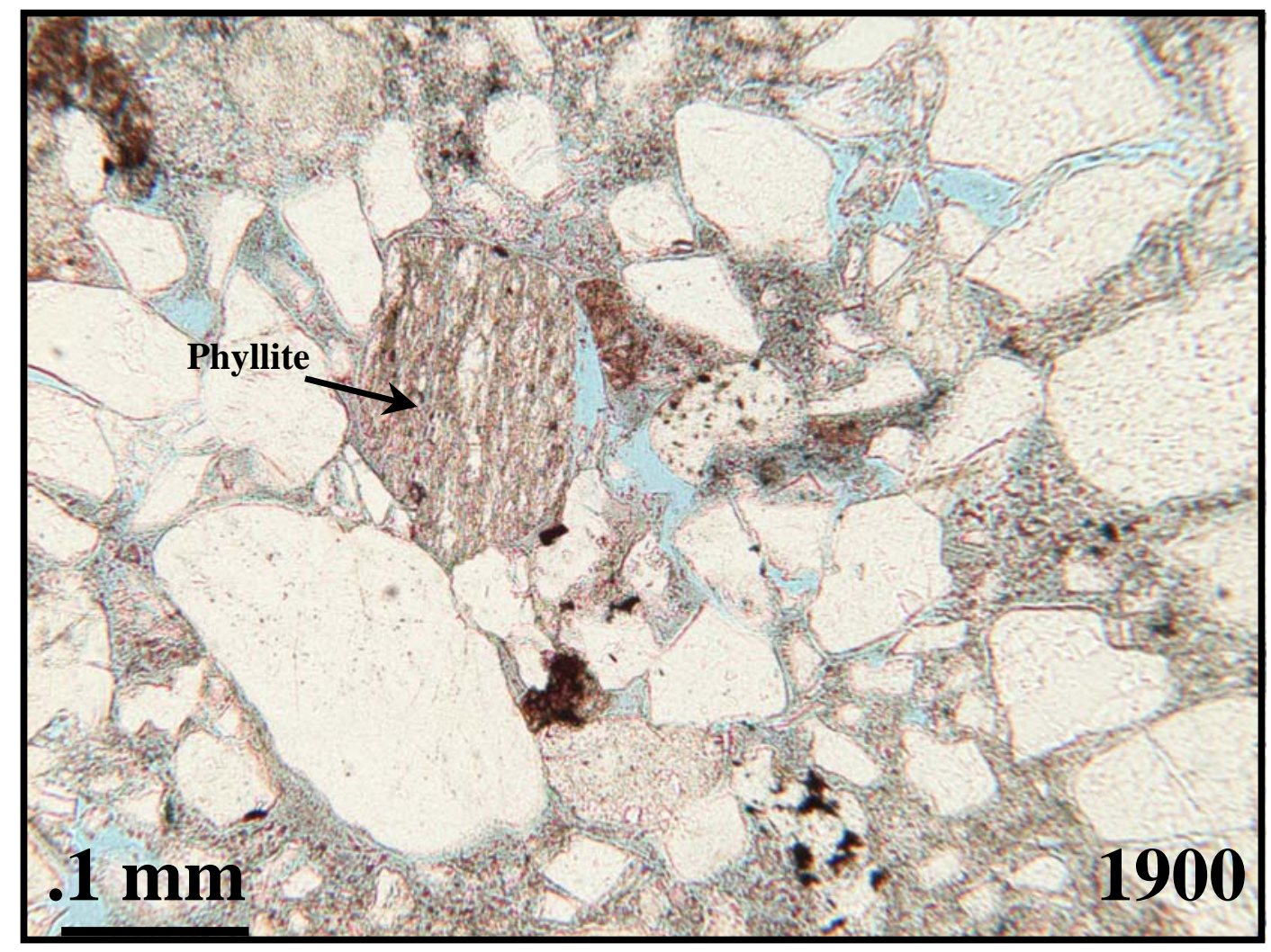

Figure 9 - Phyllite rock fragment

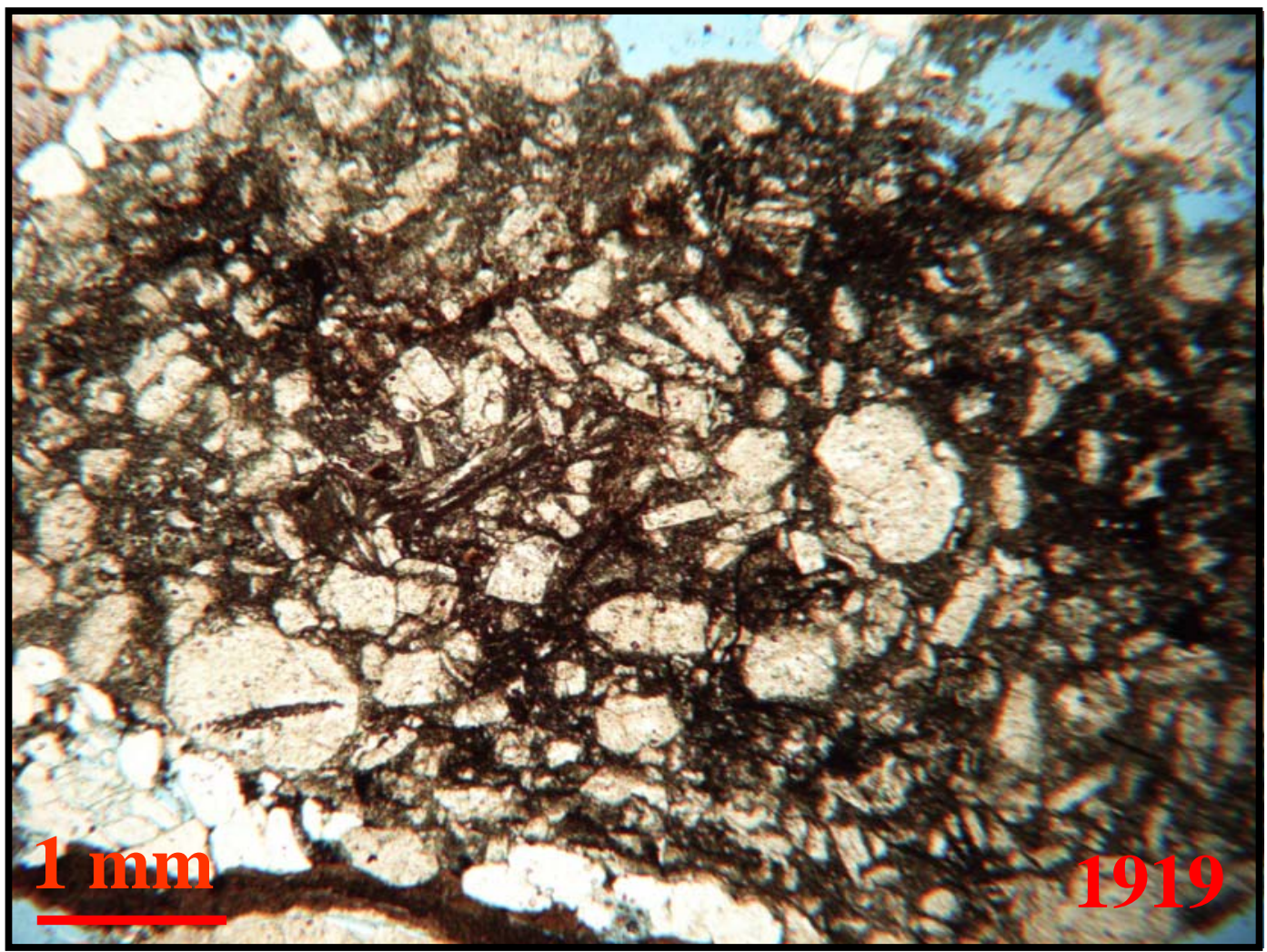

Figure 10 - Volcanic rock fragment 
plaid twinning. Many feldspars have suffered dissolution, and are preserved only as molds in thin section. In some instances a chlorite coating around a feldspar mold preserves the original euhedral to subhedral shape. Some intragranular porosity exists along the albite twins in the plagioclase feldspars.

\section{Micas}

Muscovite and biotite flakes are scattered throughout the samples. The largest grains are $0.240 \mathrm{~mm}$ in length.

\section{Chamosite}

Chamosite (Figure 11) is rare in the samples but is obvious in thin section. Chamosite is present in samples 1847, 1859, 1862, 1867, 1870, 1871, 1882, and 1889. The color is grass green, and it sometimes displays an oolitic structure around a nucleus of quartz. In other grains no internal structure can be recognized.

\section{Accessory Minerals}

Three accessory minerals, zircon (Figure 12), tourmaline and leucoxene, range up to a combined maximum of 2.33 percent. Zircon is the most common accessory mineral. It has high relief and is commonly colorless. The grains average $0.040 \mathrm{~mm}$ and are subrounded to rounded. Tourmaline, typically pleochoic in shades of green, is scarce in thin section. Grains of tourmaline average $0.040 \mathrm{~mm}$ and are subrounded. The opaque mineral leucoxene was identified by its whitish yellow color in reflected light.

\section{Matrix}

Quartz silt (Figure 13) comprises most of the matrix, ranging up to 14 percent of rock volume; the matrix includes small mica flakes. Pyrite is present in the matrix of many samples, usually replacing other grains. On average, pyrite makes up 0.91 

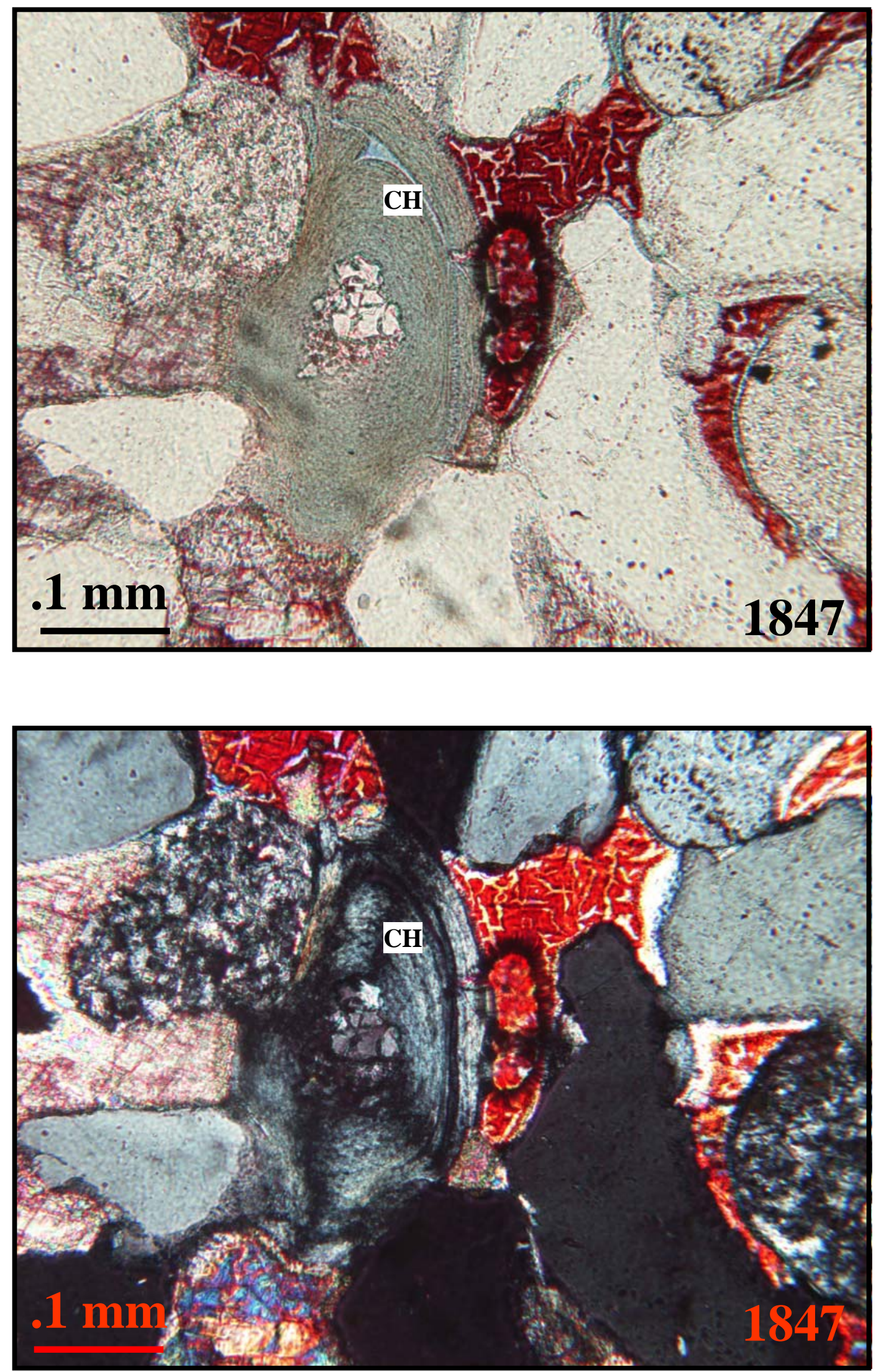

Figure 11 - Chamosite $(\mathrm{CH})$ in plane polarized light (above) and crossed polarized light (below) 


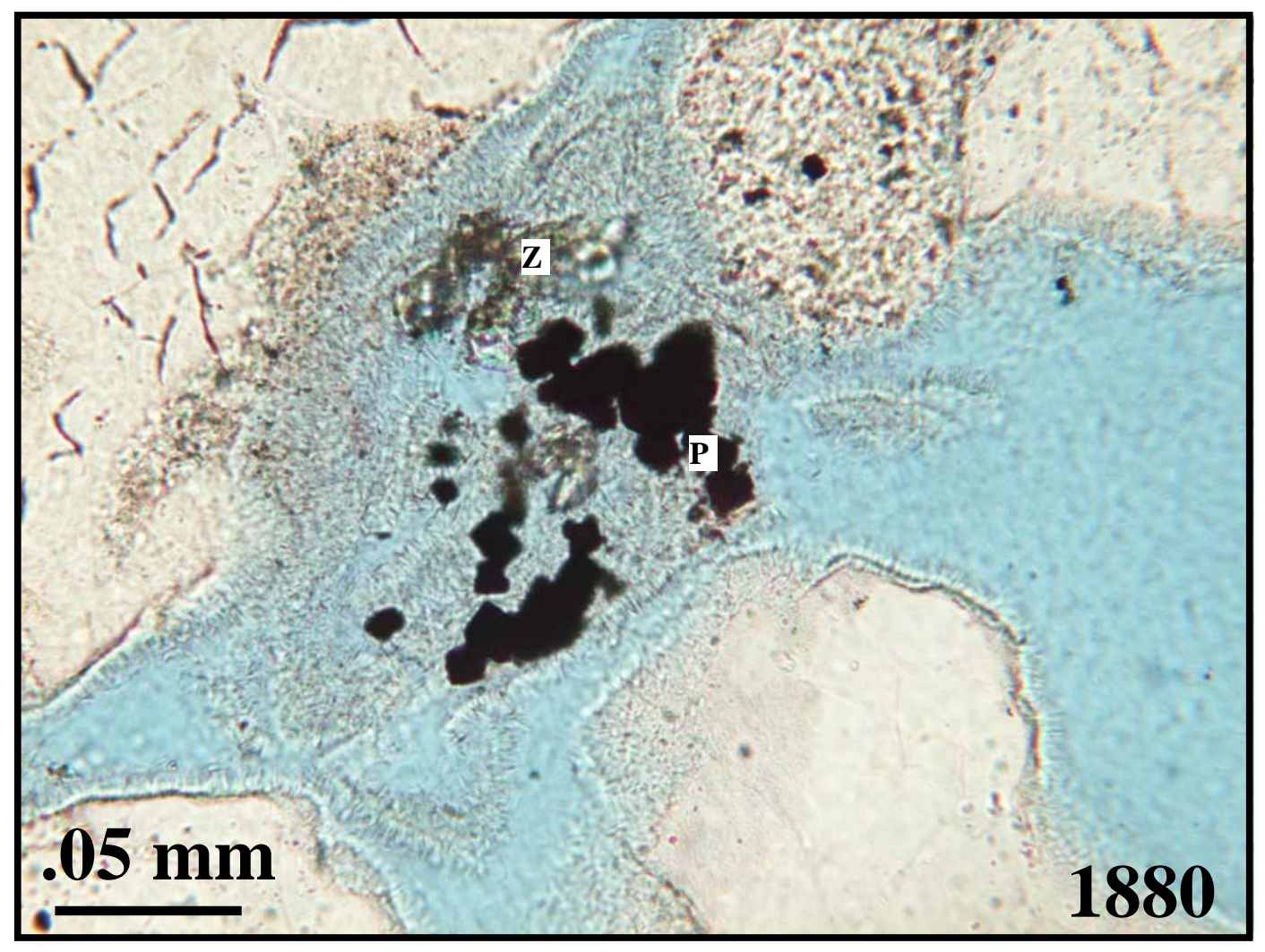

Figure 12 - Pyrite (P) and Zircon (Z).

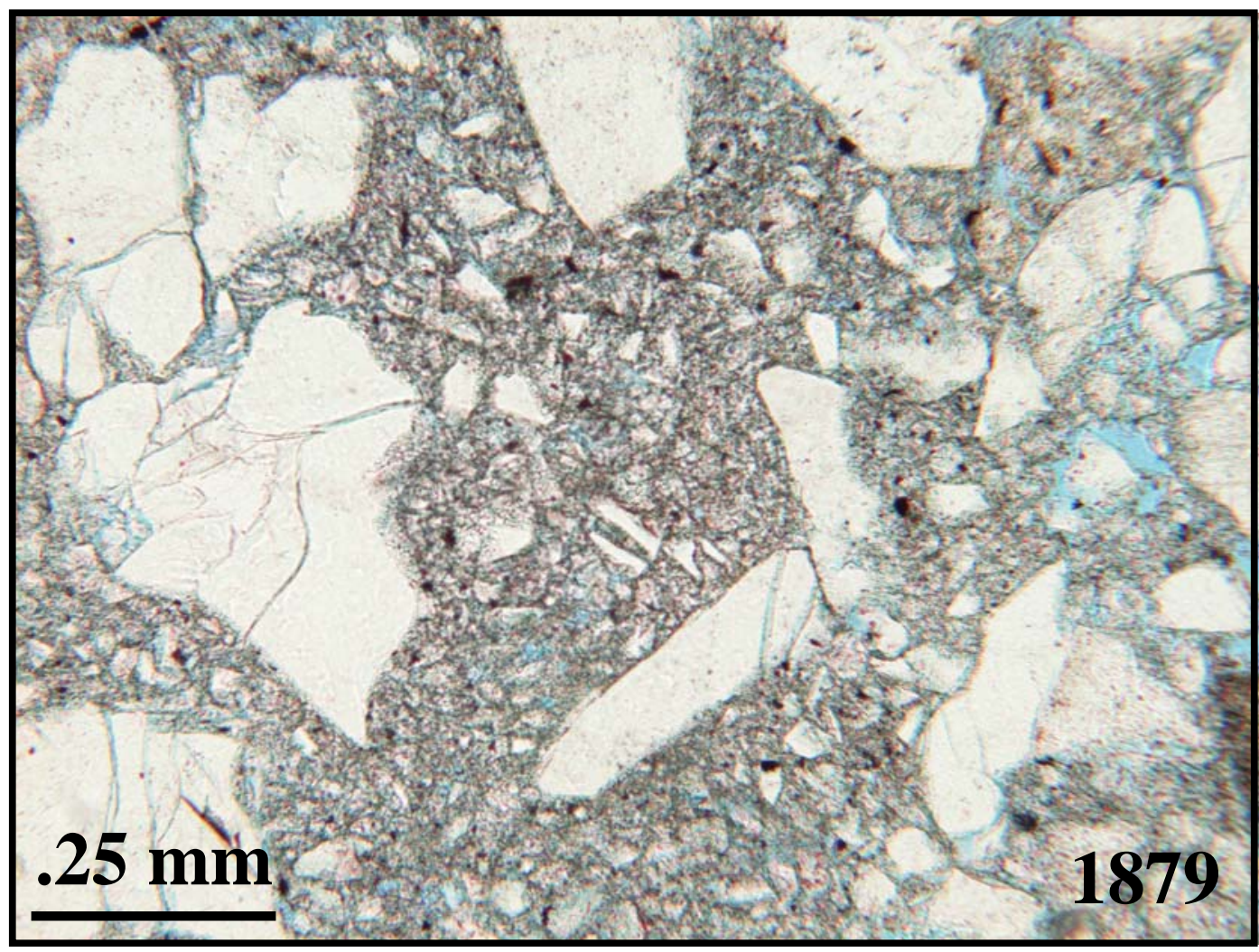

Figure 13 - Matrix of quartz silt. 
percent of the samples. The crystal shape can vary but commonly is the characteristic cube, averaging $0.02 \mathrm{~mm}$ in diameter (Figure 12). Pyrite is also concentrated along stylolitic seams in a few samples where it has replaced organic matter. Clay minerals are also present in many of the samples ranging from 0 to 2.33 percent. In some samples the clay is present as matrix, in others as clay partings. The clay is dark brown in color and likely illite.

\section{Quartz Cement}

This is the most common type of cement in the Murrysville samples, ranging from 3 to 21 percent by volume. It occurs as syntaxial quartz overgrowths (Figure 14) typically on detrital quartz. The size of the crystal varies but averages $0.100 \mathrm{~mm}$ in diameter. The shape of the cement overgrowth fills adjacent pore space. In samples with moldic pores, the quartz cement occurs as prismatic overgrowths that have grown into moldic pores.

\section{Chlorite Cement}

Chlorite occurs as rims on quartz (Figure 15) and seems to have prevented cementation by quartz overgrowths except where chlorite rims are absent or broken. Where chlorite rims are not continuous, are missing or broken, quartz cement can more easily precipitate on the grain. The chlorite crystals are acicular, their orientation perpendicular to the grain and the average thickness of the rims is $0.010 \mathrm{~mm}$. They make up 0-5 percent of most samples, with a mean volume of 3 percent. Rarely the chlorite cement forms as a fan (Figure 16) on quartz grains. 


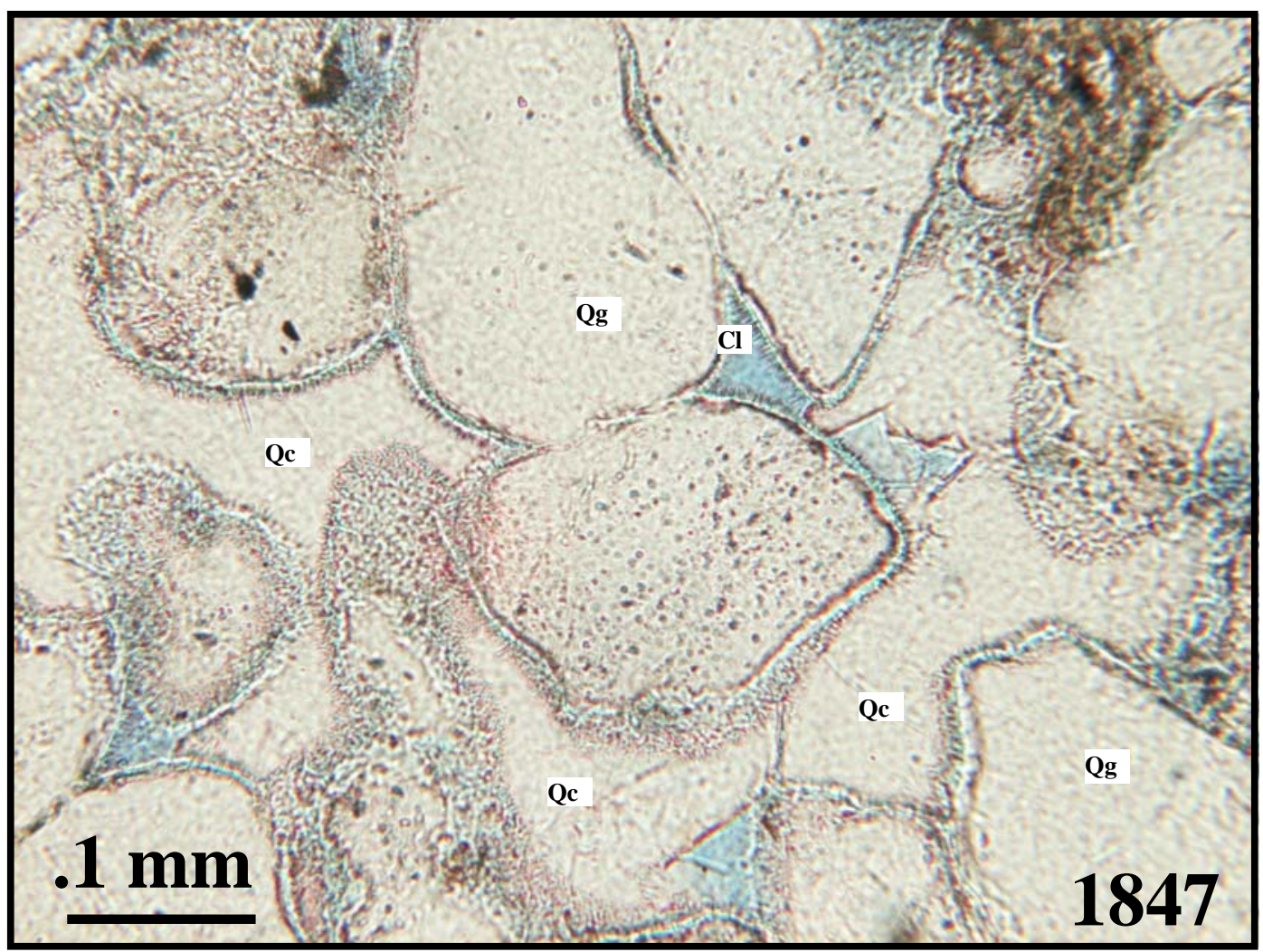

Figure 14 - Quartz cement precipitated on chlorite rims. Qg - Quartz grain; Qc - Quartz cement; Cl - Chlorite Rim

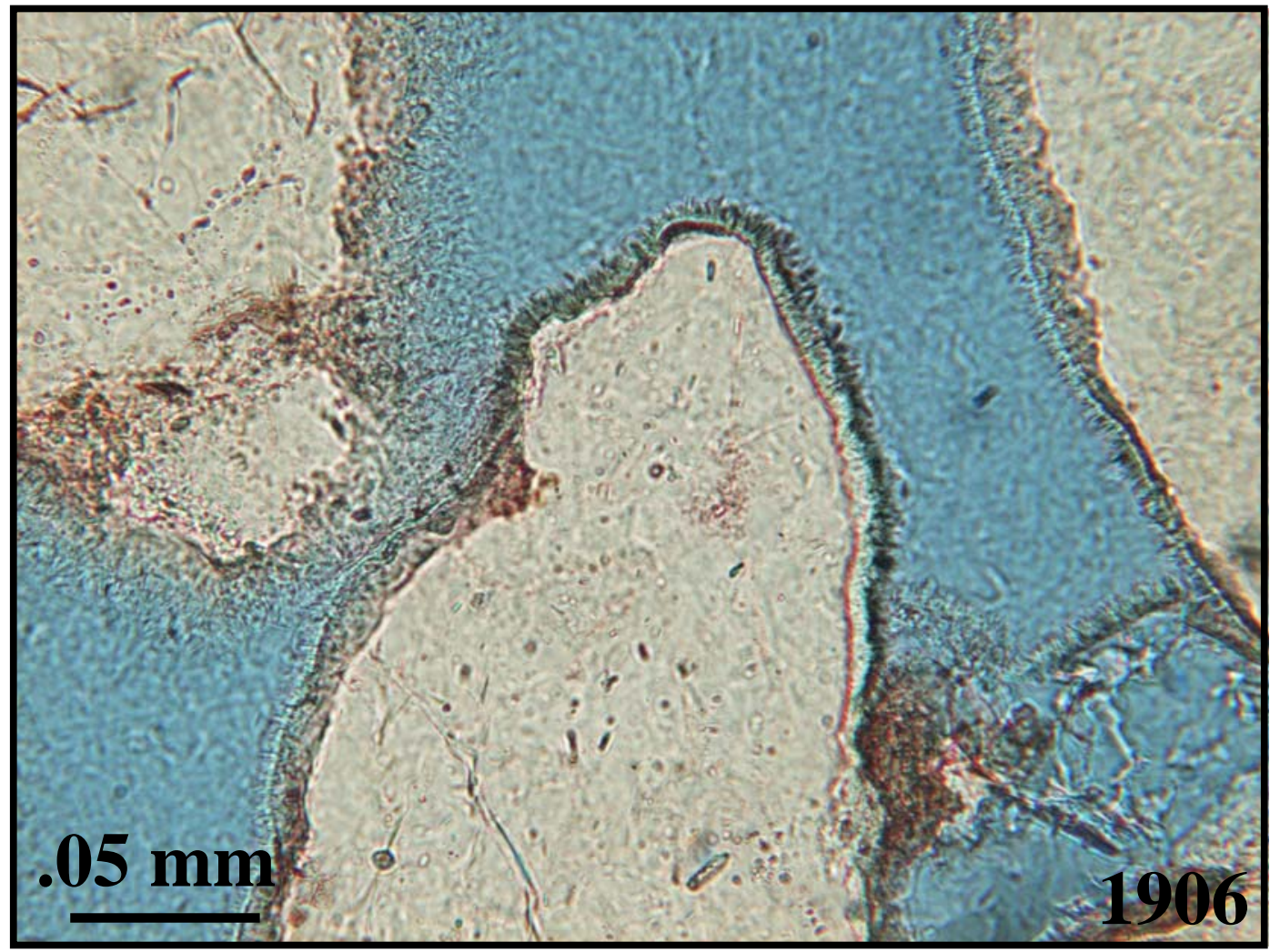

Figure 15 - Chlorite cement precipitated as needle-like rims. 


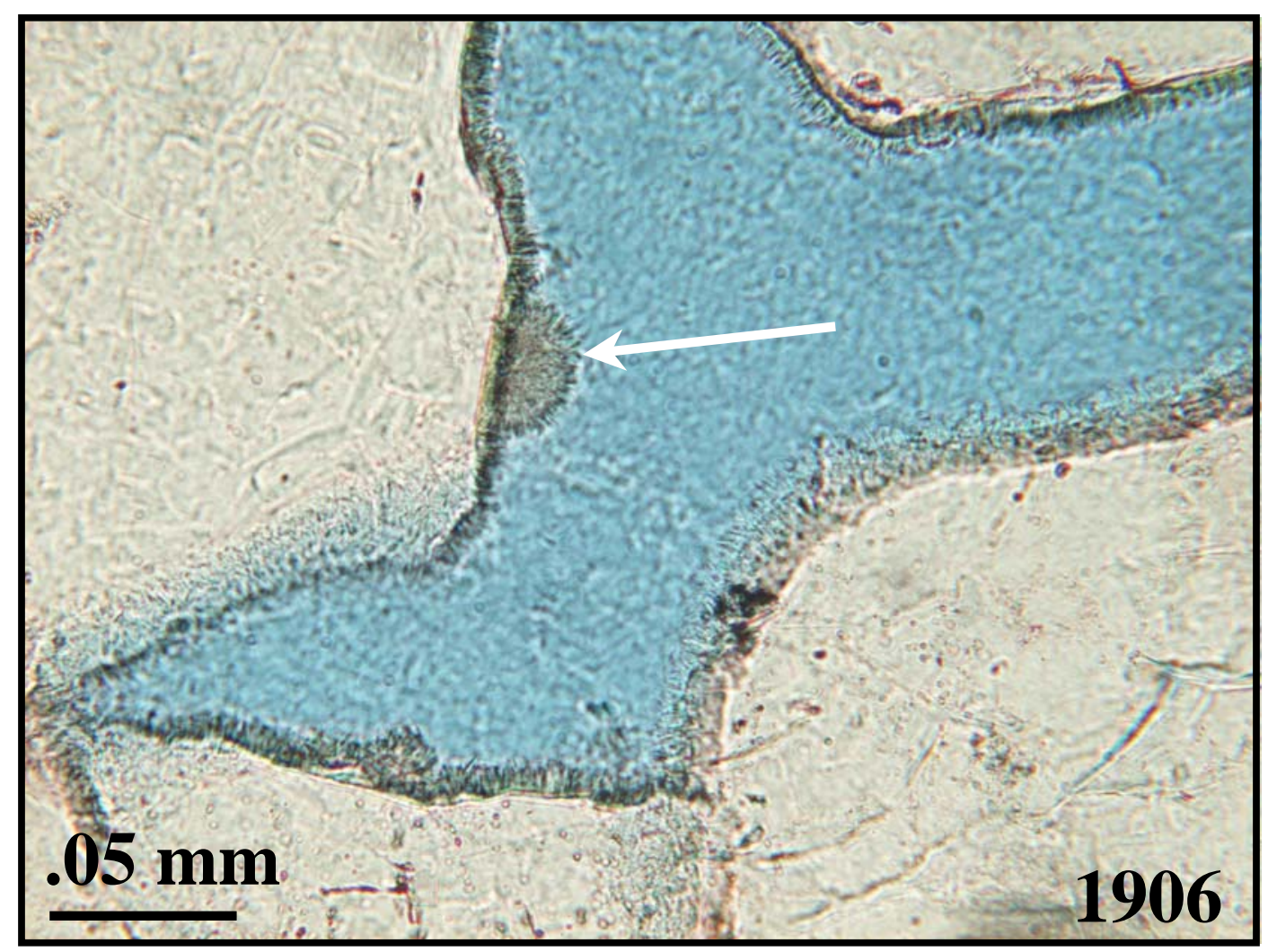

Figure 16 - Chlorite cement precipitated in a fan-like shape. 


\section{Calcite Cement}

Calcite cement (Figure 17) was identified by a stain of Alizerin red S on the thinsection samples. Calcite cement is poikilotopic but patchy, filling interconnected pores and encompassing several quartz grains in localized areas. Calcite averages 1.52 percent with a maximum of 12 percent at 1847 feet (563 meters).

\section{Siderite Cement}

Siderite cement displays euhedral rhombs with distinct crystal faces and a dark brown color. The cement is not common and is distributed in isolated patches.

\section{Pyrite}

Pyrite is found in small quantities in many samples. It is most abundantly mixed with silt.

\section{Solid Bitumen}

Bitumen is present in small amounts in some samples. At depth 1904 feet (580 meters) bitumen is relatively abundant along with pyrite in a stylolite. 


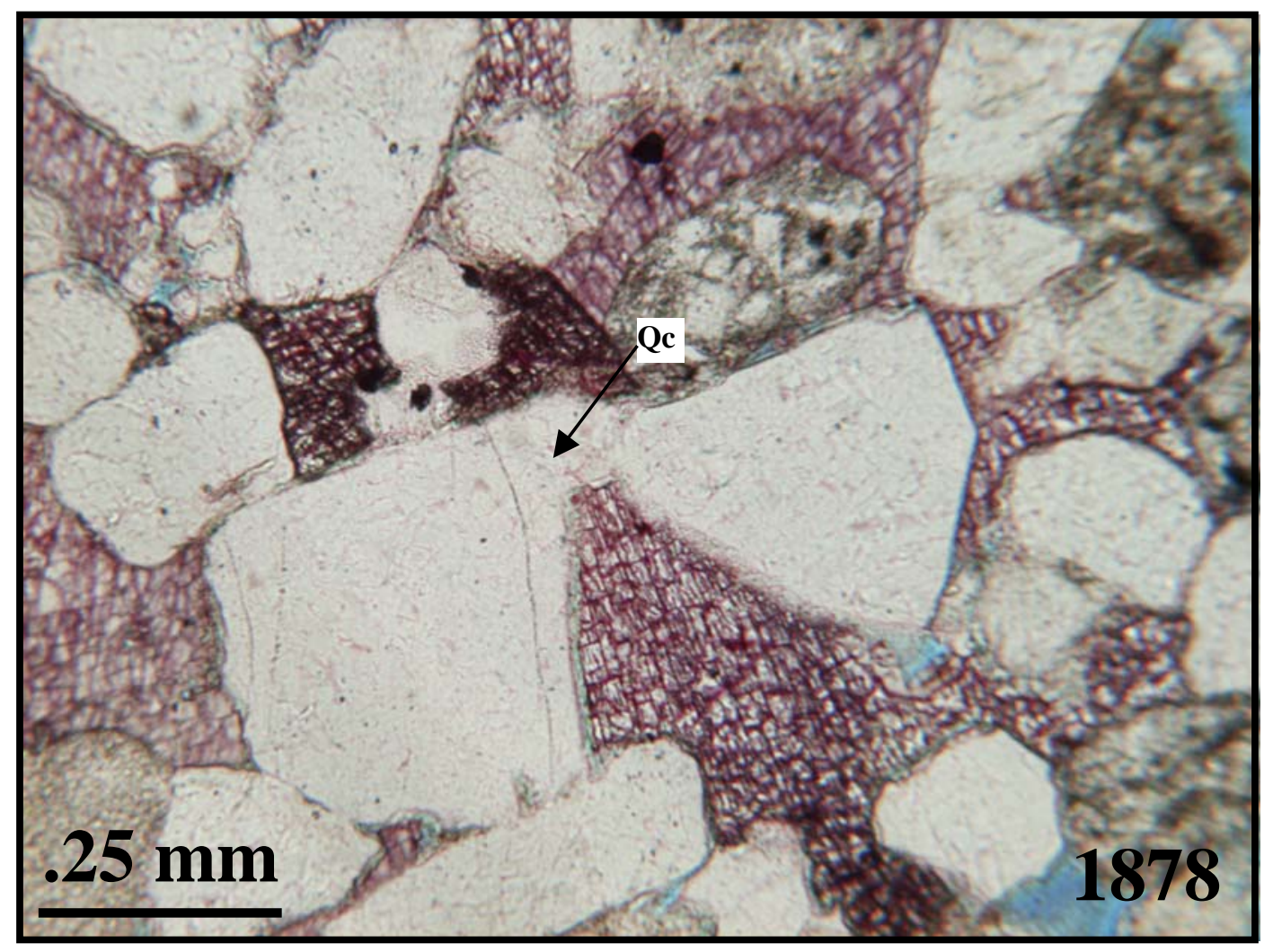

Figure 17 - Calcite cement (pink) and quartz cement (Qc) 


\section{MICROFACIES}

Five sedimentary microfacies are recognized based upon mineral content and texture as observed in thin section. The facies are quartzarenite, sublitharenite A, sublitharenite B, conglomerate and shale. Petrographic data for the 45 sandstone samples were plotted on a QFL ternary diagram (Fig $18 \mathrm{a}, \mathrm{b}$ ). In naming these, the guidelines given by Folk (1974) were followed, except that chert has been included with quartz rather than lithics. For quartzarenite $\mathrm{Q} / \mathrm{Q}+\mathrm{F}+\mathrm{L}$ is 95 to 100 percent, sublitharenite $\mathrm{A}$ has a $\mathrm{Q} / \mathrm{Q}+\mathrm{F}+\mathrm{L}$ of 90 to 95 percent, sublitharenite $\mathrm{B}$ with $\mathrm{Q} / \mathrm{Q}+\mathrm{F}+\mathrm{L}$ equal to 80-90 percent . Two additional groups, conglomerate and shale, do not appear on the QFL diagram; they are classified on grain size. Figure 19 shows how each microfacies is distributed with depth. Figures 20 and 21 show how quartz decreases with depth and phyllite grains content increases with depth. Point count averages for microfacies are presented in Table 1.

\section{Quartzarenite}

Twenty-two sandstone samples are quartzarenites (Figure 22). Monocrystalline quartz is the dominant grain type; undulose and polycrystalline quartz are also present. The quartz commonly has inclusions, usually of mica (Figure 23). Most quartz grains are subrounded and mean size ranges from $0.33 \mathrm{~mm}$ to $0.45 \mathrm{~mm}$. Sorting seems to be a function of grain size; as size decreases, sorting improves from poor to moderate.

Detrital chert and shale rock fragments, rounded and elongate in shape, are scattered throughout the samples. Small quantities of ductile phyllite rock fragments commonly show ductile deformation deformed around the more competent grains. Feldspars, both whole and partially leached (Figure 24), are present. Large flakes of 


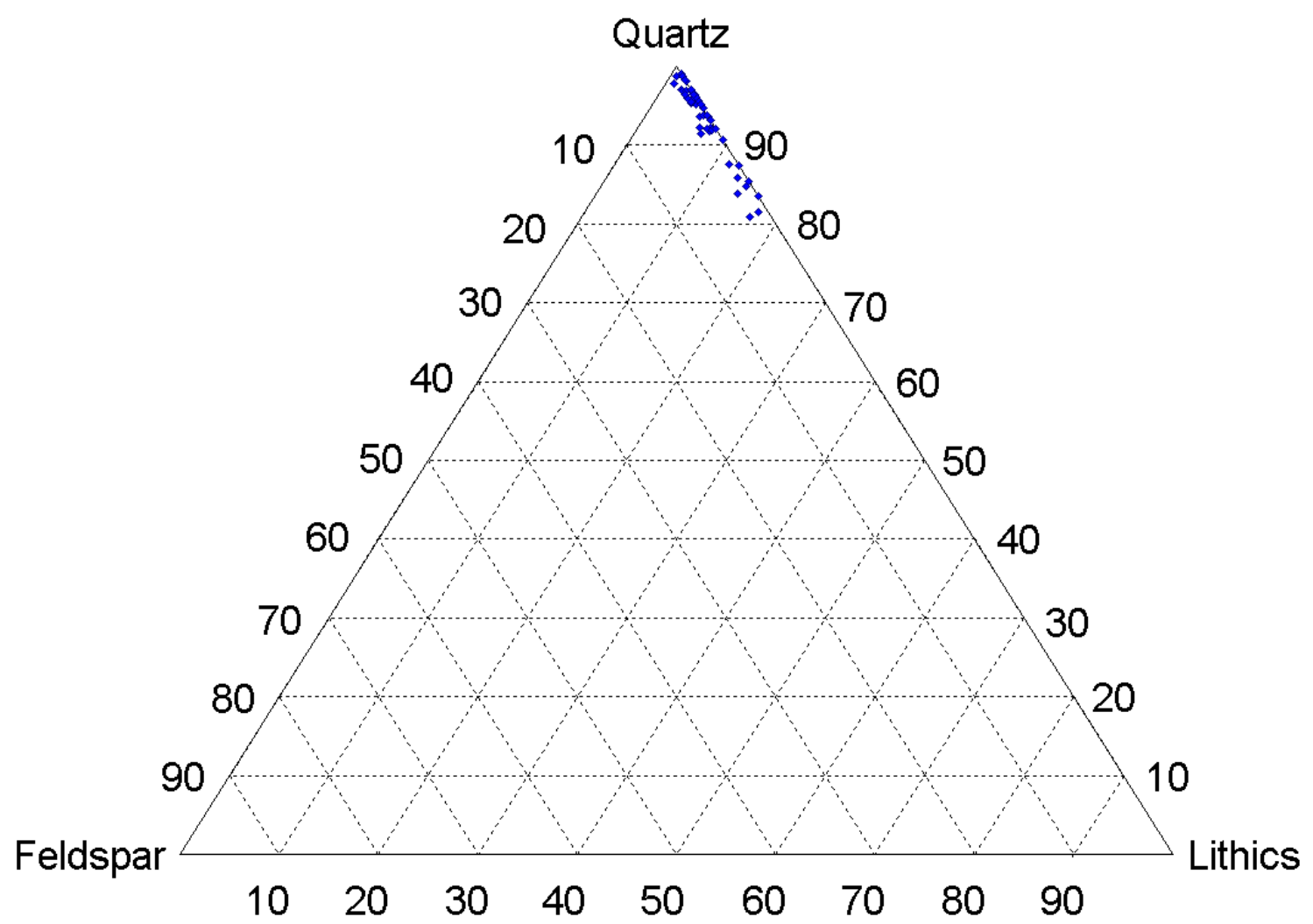

Figure 18a - QFL Diagram for the Murrysville.

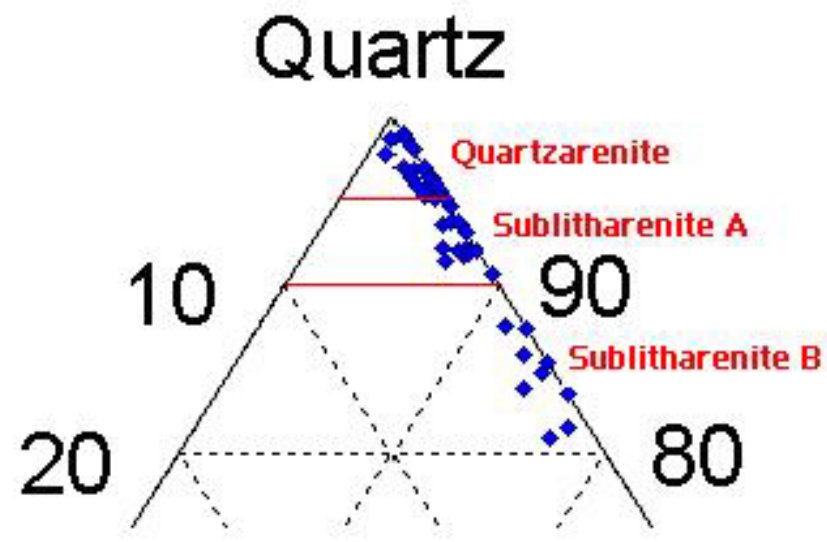

Figure 18b - close-up of the QFL diagram 


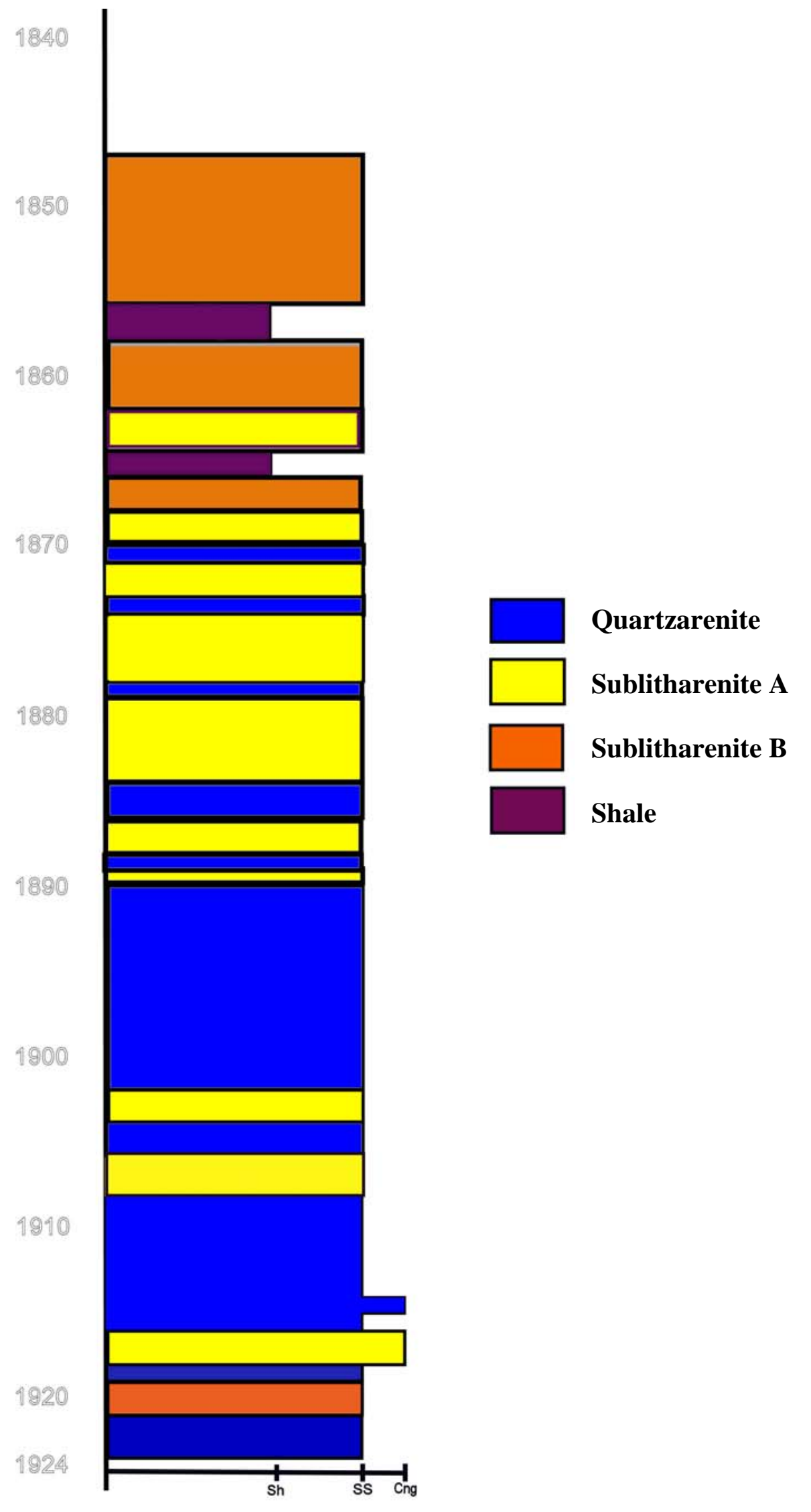

Figure 19 - Stratigraphic column showing how microfacies and rock types are distributed with depth 
Figure 20 -- Percent Quartz Grains vs Depth

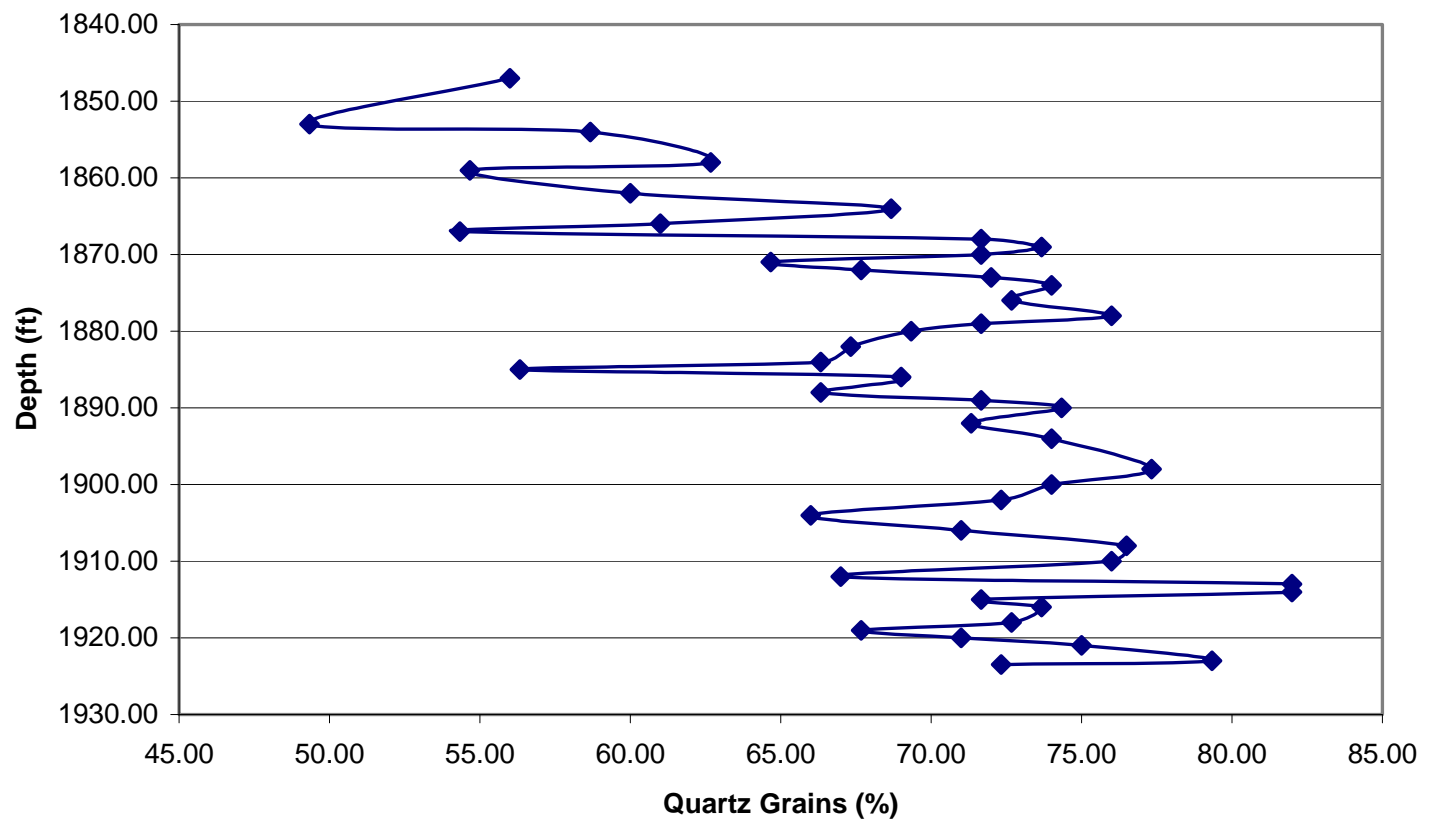

Figure 21 -- Percent Phyllite Rock Fragments vs Depth

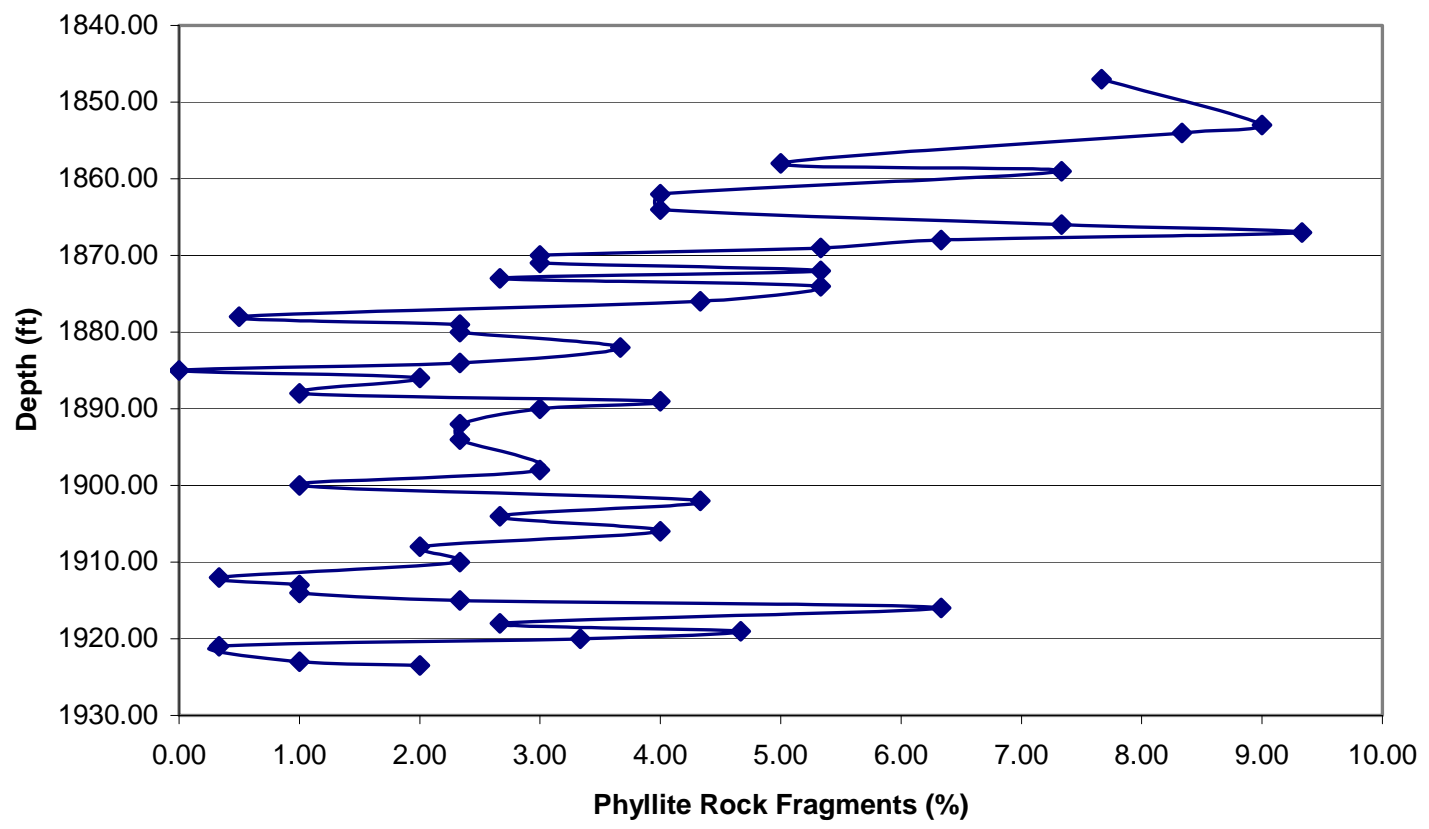


Table 1 - Mean percent of point-counted constituents for 4 microfacies (excluding shale).

Grains

Monocrystalline Quartz
Undulose Quartz
Chert
Polycrystalline Quartz
Elongated Polycrystalline Quartz
Metamorphic Quartz w/ Mica

Quartzarenite Sublitharenite A Sublitharenite B Conglomerate
57.31

2.17

0.54

7.47

0.29

3.48

71.25

Lithics

Illite Rock Fragments

Phyllite Rock Fragments

High Grade Metamorphics

Micas

Feldspars

Feldspars (Plagioclase and Potassium)

Accessory Minerals

Pyrite

Zircon, Tourmaline, Leucoxene, Chamosite

Bitumen

Chlorite Rims

Matrix

Silt Matrix

Clay Matrix

\section{Cement}

Quartz Cement

Calcite Cement

Siderite Cement

\section{Porosity}

Intergranular Porosity

Moldic Porosity

Intragranular Porosity (Metamorphic)

Intragranular Porosity (Quartz)

Intragranular Porosity (Feldspar)

Intragranular Porosity (Shale)

Intragranular Porosity (Unidentifiable)

Fracture Porosity
0.25

2.17

0.09

0.52

0.31

0.78

0.43

0.02

2.98

2.89

0.06

6.29

1.81

0.05

7.02

1.48

0.50

0.86

0.17

0.03

0.05

0.00

Total
57.79

1.88

0.94

5.54

0.21

3.13

69.48

0.60

3.83

0.10

0.29

0.42

1.21

0.54

0.00

2.83

3.50

0.06

5.08

1.42

0.06

6.19

2.52

0.25

1.15

0.15

0.06

0.25

0.00

100.00
47.22

2.30

0.44

6.41

0.30

2.81

59.48

3.00

6.89

0.37

0.67

0.56

0.00

0.93

0.67

0.00

3.22

0.89

0.41

0.17

0.00

5.83

0.50

0.17

38.17

1.33

0.33

35.17

0.83

2.00

77.83

0.00

3.67

0.00

0.50

0.00

0.33

0.00

3.33

8.93

3.07

0.00

5.67

2.26

0.67

1.15

0.48

0.33

0.33

0.04

100.00
5.83

0.50

1.00

0.17

0.17

0.00

0.00

0.00

100.00 


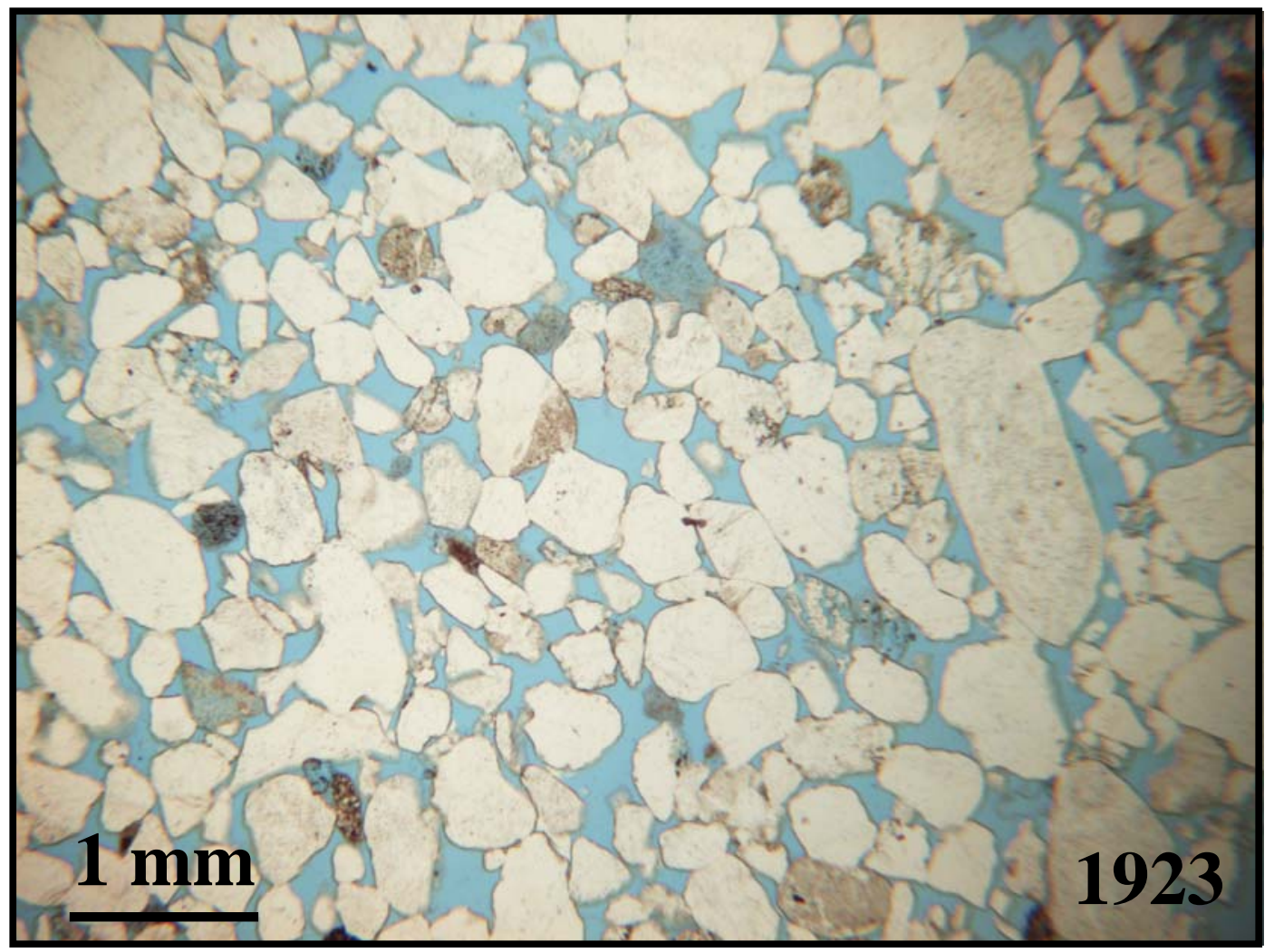

Figure 22 - Typical quartzarenite with loose packing, seemingly floating grains with few point contacts.

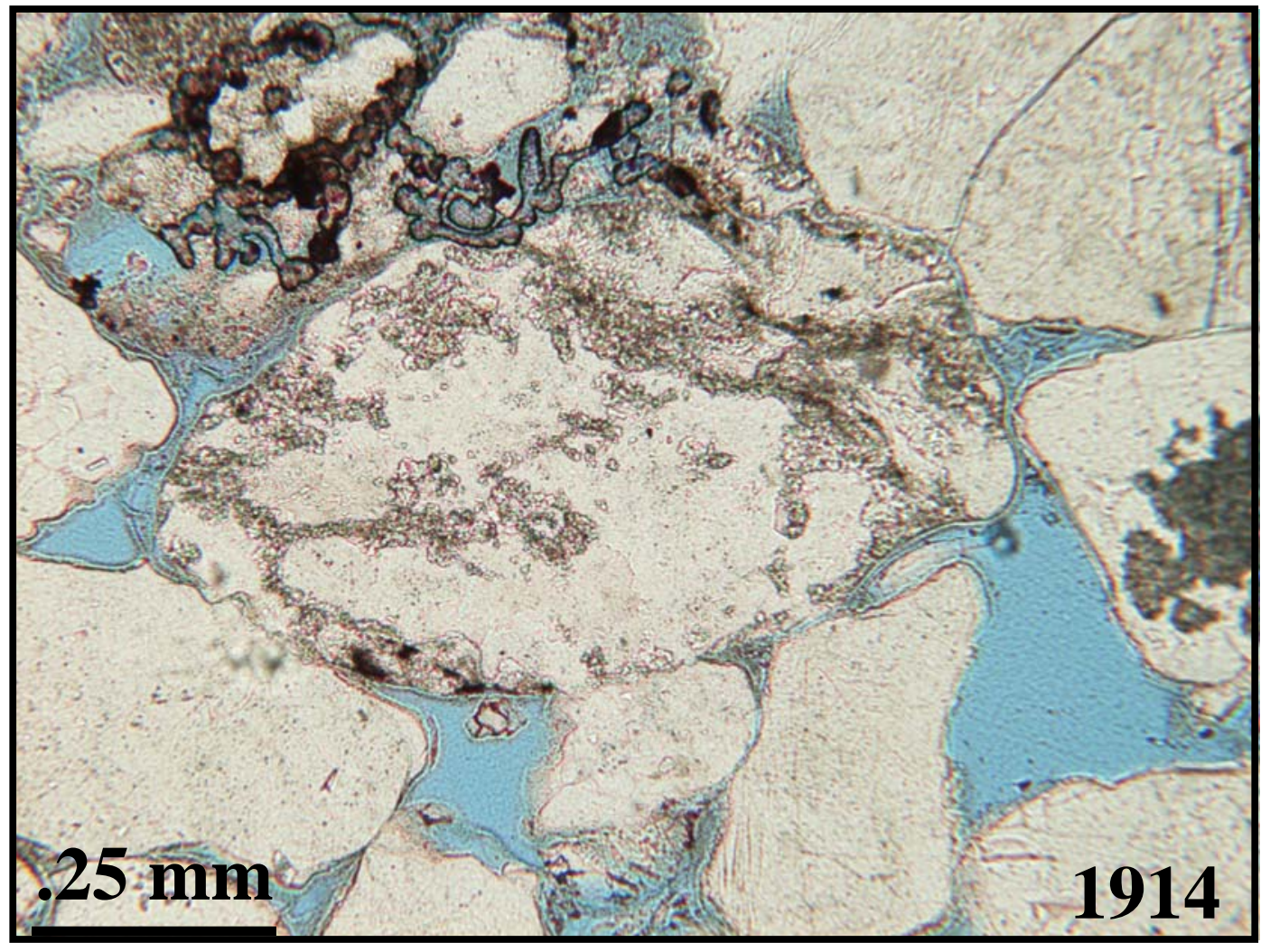

Figure 23 - Quartz grain with inclusions of mica. 


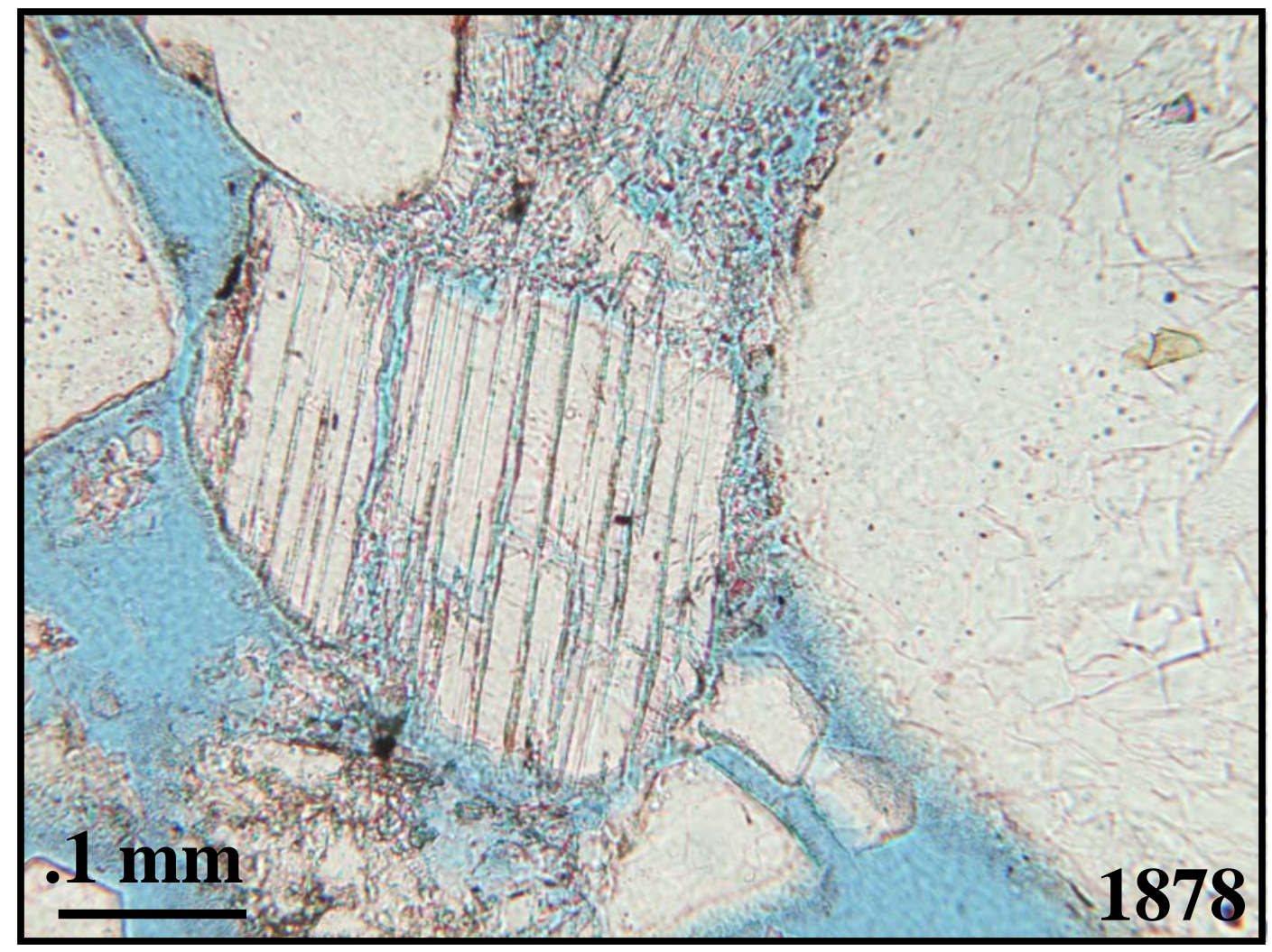

Figure 24 - Plagioclase feldspar that shows preferential dissolution along twinning planes 
muscovite and biotite micas are present in the quartzarenites. Long flakes wrap around the other grains. Muscovite is the more abundant and is commonly present with the silt. Accessory minerals include tourmaline, zircon and leucoxene. The matrix (Figure 13) consists of silt-sized quartz, pyrite and micas. Clay minerals, zircon and tourmaline are commonly in the matrix as well.

\section{Sublitharenites}

Twenty-three sandstone samples are sublitharenites (Figure 25). Sublitharenites are divided into two groups, A and B. The division within the sublitharenites group is based on the percent quartz and percent lithics (Figure 18b). Group A has more quartz and fewer lithics than Group B as shown in Table 1, but otherwise the two microfacies are quite similar. The most abundant grain type is monocrystalline quartz. Polycrystalline quartz, with and without mica inclusions, is also abundant, as is undulose quartz. Grains are usually subrounded, and the average sizes range widely from $0.12 \mathrm{~mm}$ to $1.10 \mathrm{~mm}$. Chert is scattered throughout the samples.

Other grains include phyllite rock fragments (Figure 9) ranging from 9.33 percent to being absent. Sample at depth 1919 (584.9) contains a volcanic clast (Figure 10) with lath-shaped plagioclase. Feldspars (Figure 26), mostly plagioclase but some K-feldspar and microcline, are present.

Shale rock fragments are a minor component. One a large clast $(3.1 \mathrm{~mm})$ at depth 1919 feet (584.9 meters), and one shale parting with a pelleted texture is observed at 1920 feet (585.2 meters). 


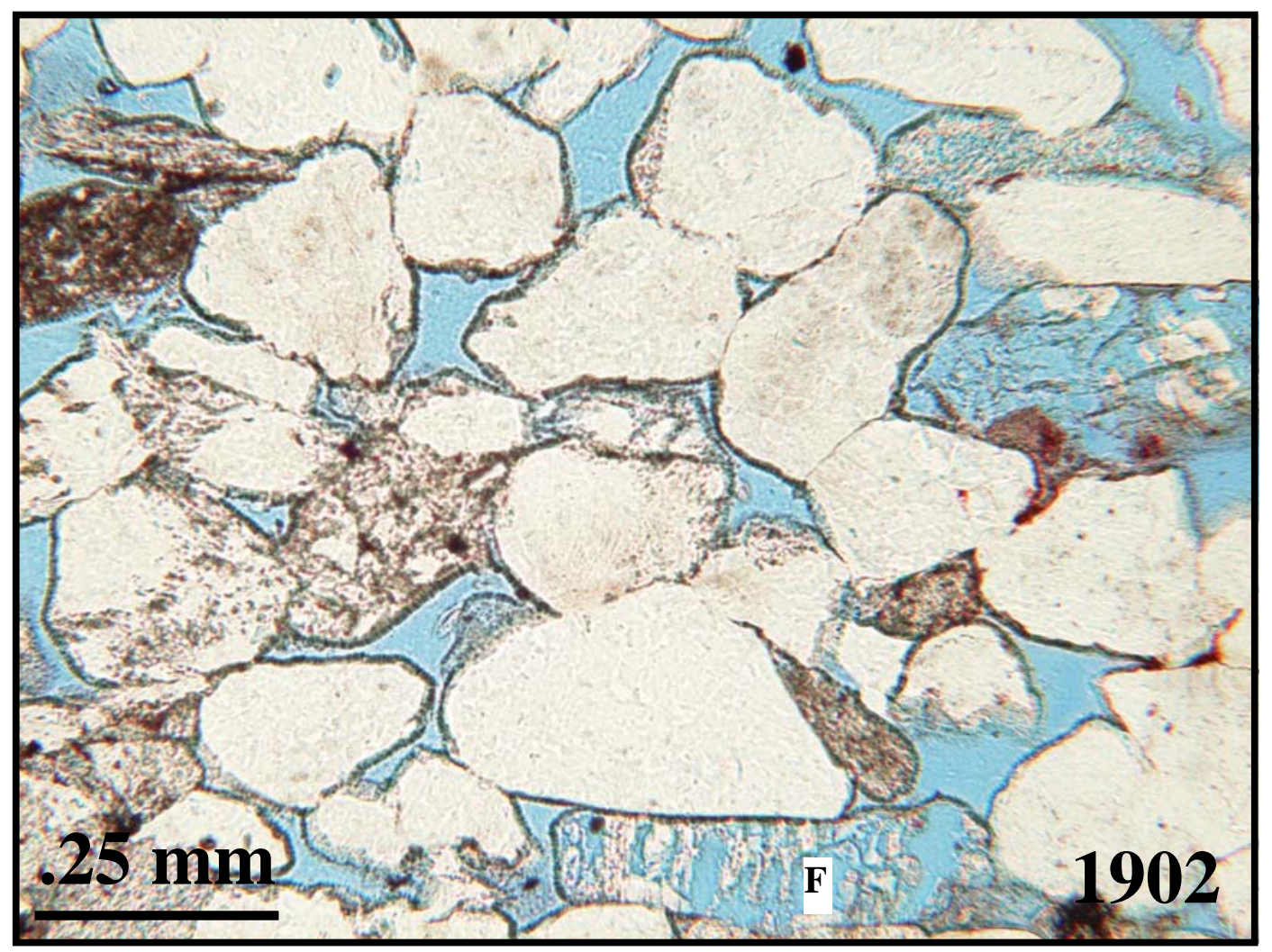

Figure 25 - Sublitharenite A - white is quartz, dark minerals are rock fragments and blue shows intergranular porosity. Also remnants of a feldspar (F) can be seen.

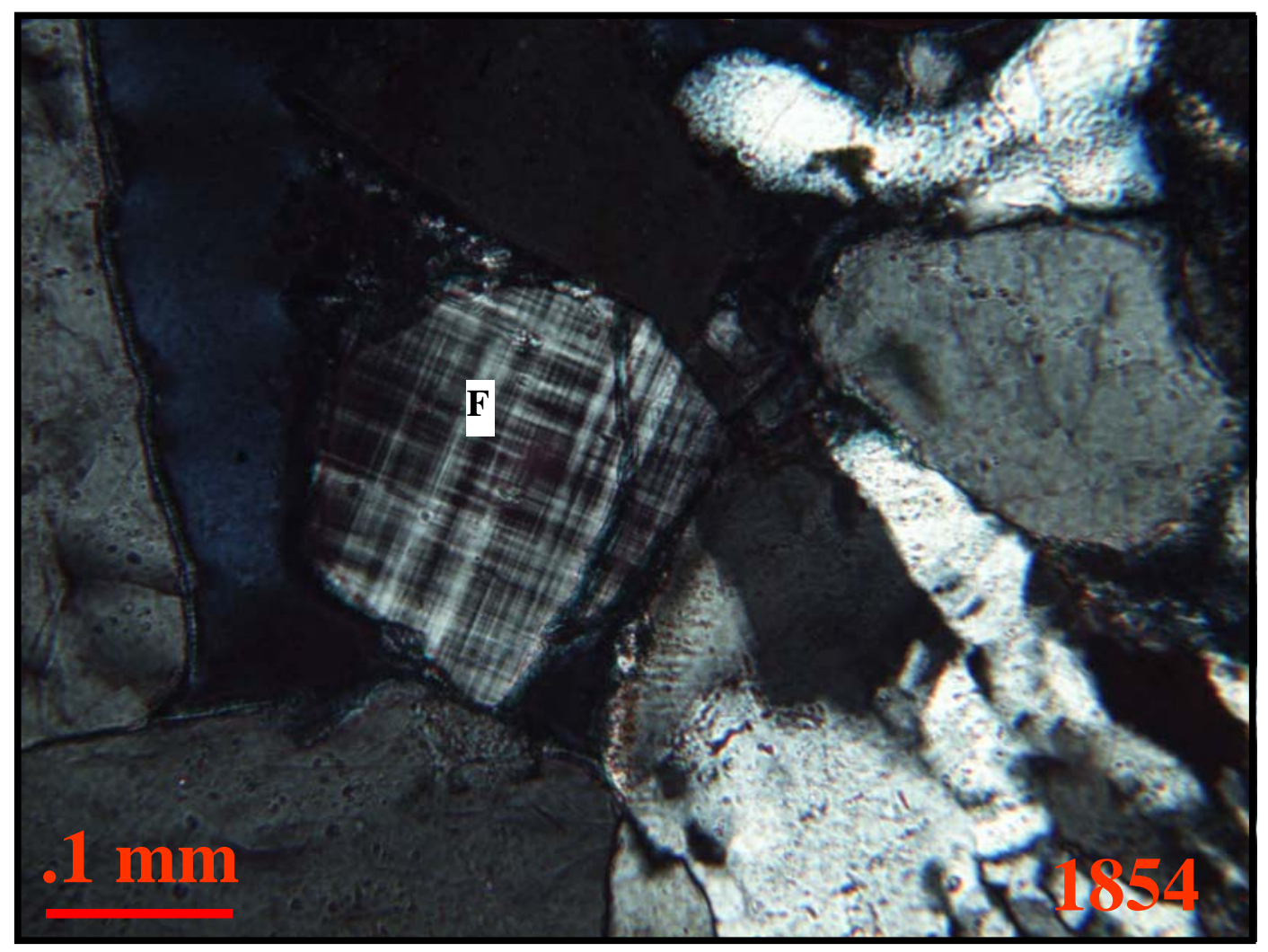

Figure 26 - A fractured feldspar (F) grain in cross polarized light. 
Muscovite and biotite are scattered throughout the samples. Muscovite is more abundant and is commonly mixed with the silt. Long flakes of muscovite most often bend around surrounding grains. Other accessory minerals include tourmaline, zircon and leucoxene.

Silt and clay matrix are common in many of the samples.

\section{Conglomerate}

Two samples of conglomerate (Figure 27) occur at depths of 1914 feet (583.4 meters) and 1916 feet (584.0 meters) near the base of the formation. If plotted on the QFL diagram, one of the conglomerates would be a quartzarenite, and the other, a sublitharenite.

The most abundant grain types are monocrystalline quartz and polycrystalline quartz. The average grain size is 2.40 and $2.50 \mathrm{~mm}$ (granule) for the two samples. The largest grain is $9.35 \mathrm{~mm}$ in diameter and is polycrystalline quartz. Other grains that are abundant include undulose quartz and chert.

Only a few shale rock fragments and phyllite rock fragments occur in the quartzarenite conglomerate at depth 1914 feet (583.4 meters). The sample at 1916 feet (584.0 meters), a sublitharenite conglomerate, has a higher amount of phyllite rock fragments. Small amounts of muscovite are scattered throughout this conglomerate sample. Both samples contain traces of leucoxene.

\section{Shale}

Two of the forty-nine samples are shale (Figure 28). Both are illite in composition and contain small amounts of quartz, mica and pyrite. They are laminated and exhibit several small burrows in thin section. These samples were not point counted. 


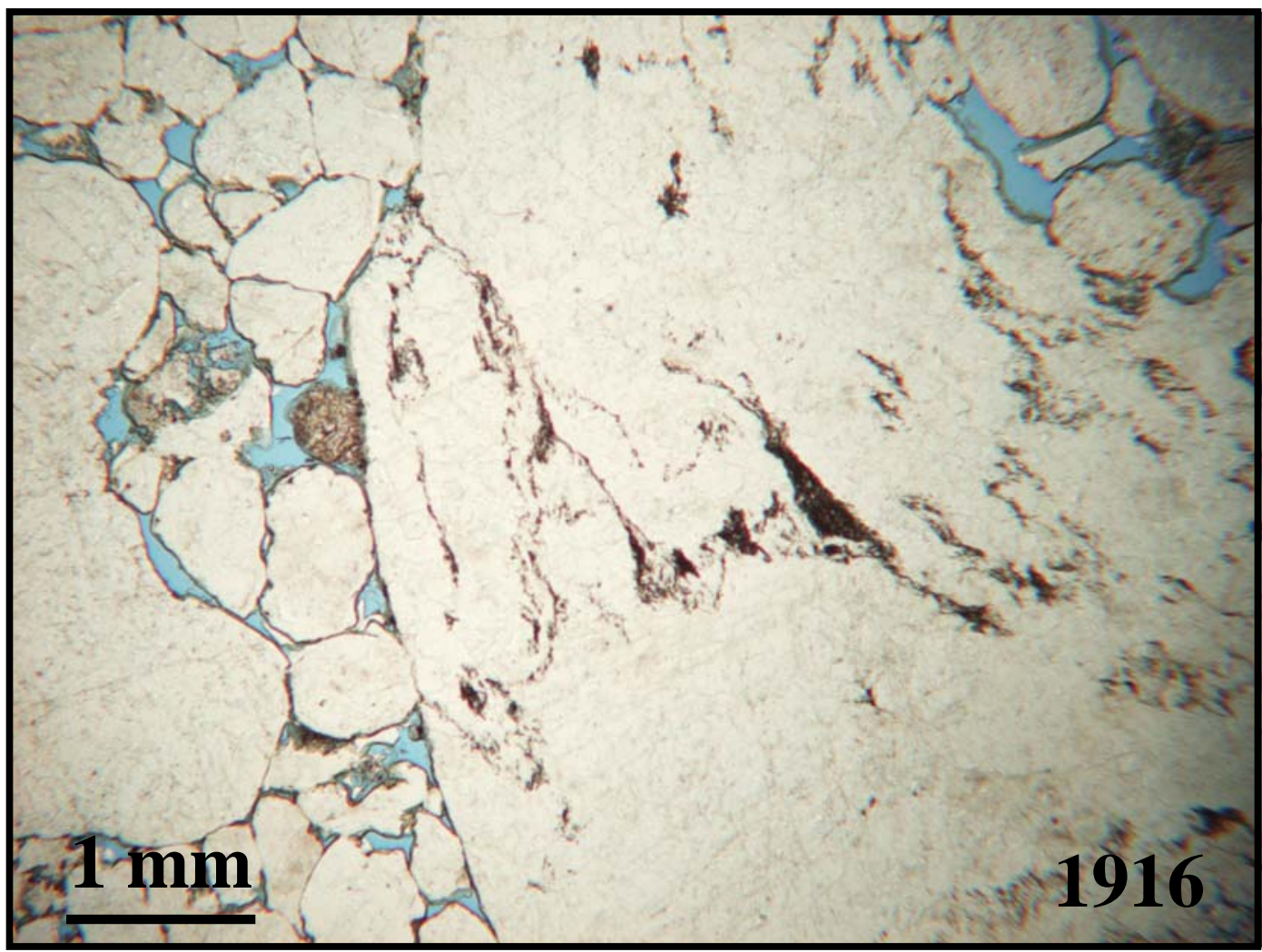

Figure 27 - Conglomeratic polycrystalline quartz grain. 

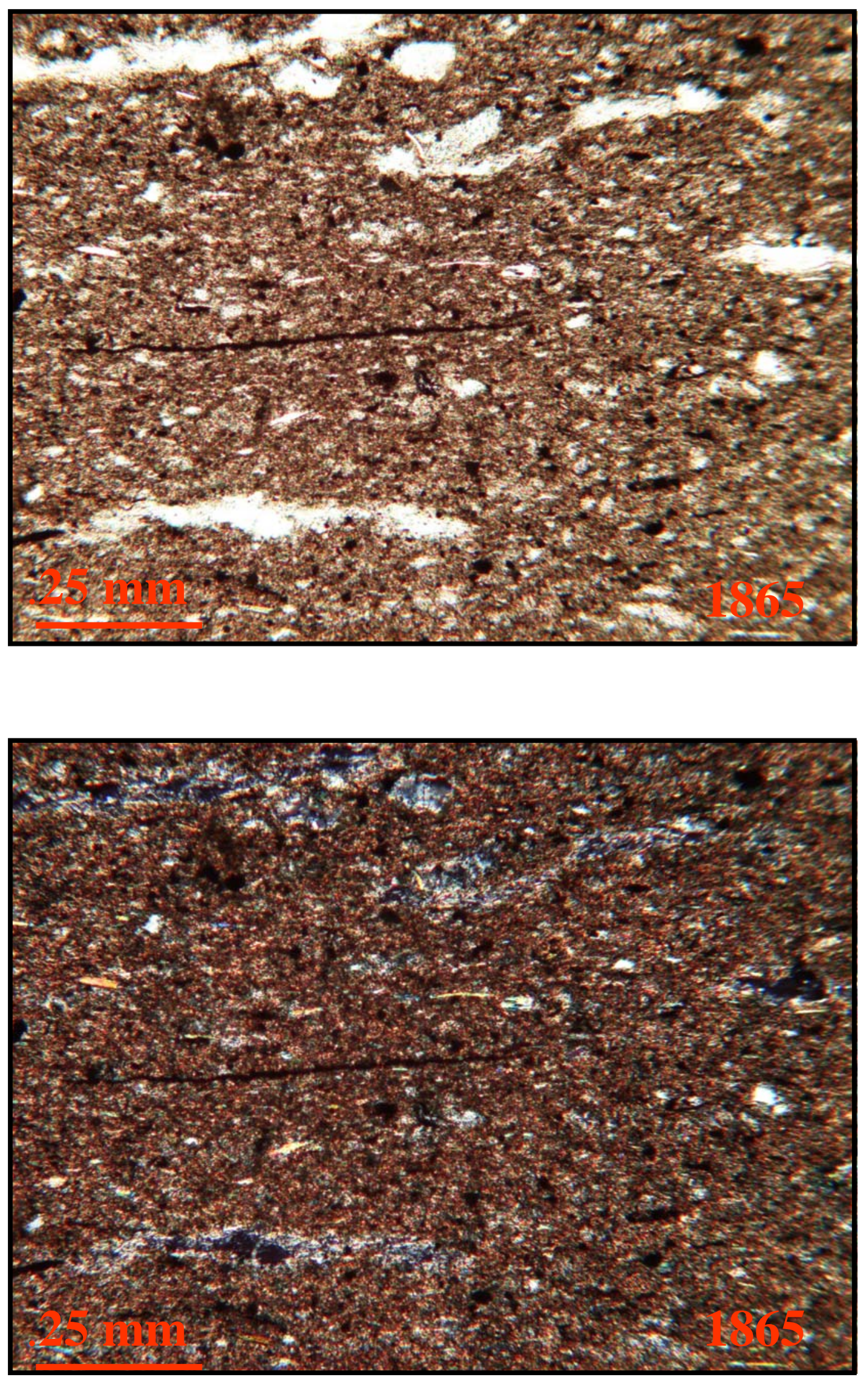

Figure 28 - Shale with layers of quartz silt in Plane Polarized Light (above) and Cross Polarized Light (below). Black streaks are most likely organic matter. 


\section{DEPOSITIONAL HISTORY OF MURRYSVILLE}

\section{Cussewago Sandstone $=$ lower Murrysville sandstone}

Forty miles (64 kilometers) to the east of the Snyder \#3 well, the Murrysville outcrops near Cramer, Pennsylvania, along PA Route 403 (Harper and Laughrey, 1989). Harper and Laughrey studied the outcrop and, their stratigraphic column is presented in Figure 29. The Murrysville is 97 feet (29.6 meters) thick in this location and is light to moderately olive brown in color. The formation base is a disconformity lying on the Riceville or Oswayo Shale (Harper and Laughrey, 1989). The lower section of the Murrysville, 67 feet thick (20.4 meters) and equivalent to the Cussewago Sandstone, is medium- to coarse- grained. This section is moderately sorted, except for the conglomerate base that is poorly sorted. The Cussewago displays a number of sedimentary features, the most abundant being trough cross-stratification. Other structures include tabular cross-stratification, planar stratification, and current-ripple laminations. The lower bounding surfaces of the sets of trough cross-beds are marked by shale-chip conglomerate lags. Scour surfaces and groove casts are found at the bases of most trough cross-bedded sets. Paleocurrent directions vary between $\mathrm{N} 40^{\circ} \mathrm{W}$ and $\mathrm{N} 60^{\circ} \mathrm{W}$ (Harper \& Laughrey, 1989).

Harper and Laughrey (1989) interpreted the lower Murrysville at this outcrop as a braided river that flowed across a coastal plain or lower delta-plain. The composition and texture of the lower Murrysville sandstone are typical of fluvial sands. Sedimentary structures, the lack of marine fossils and the presence of plant fossils support an alluvial depositional setting. 


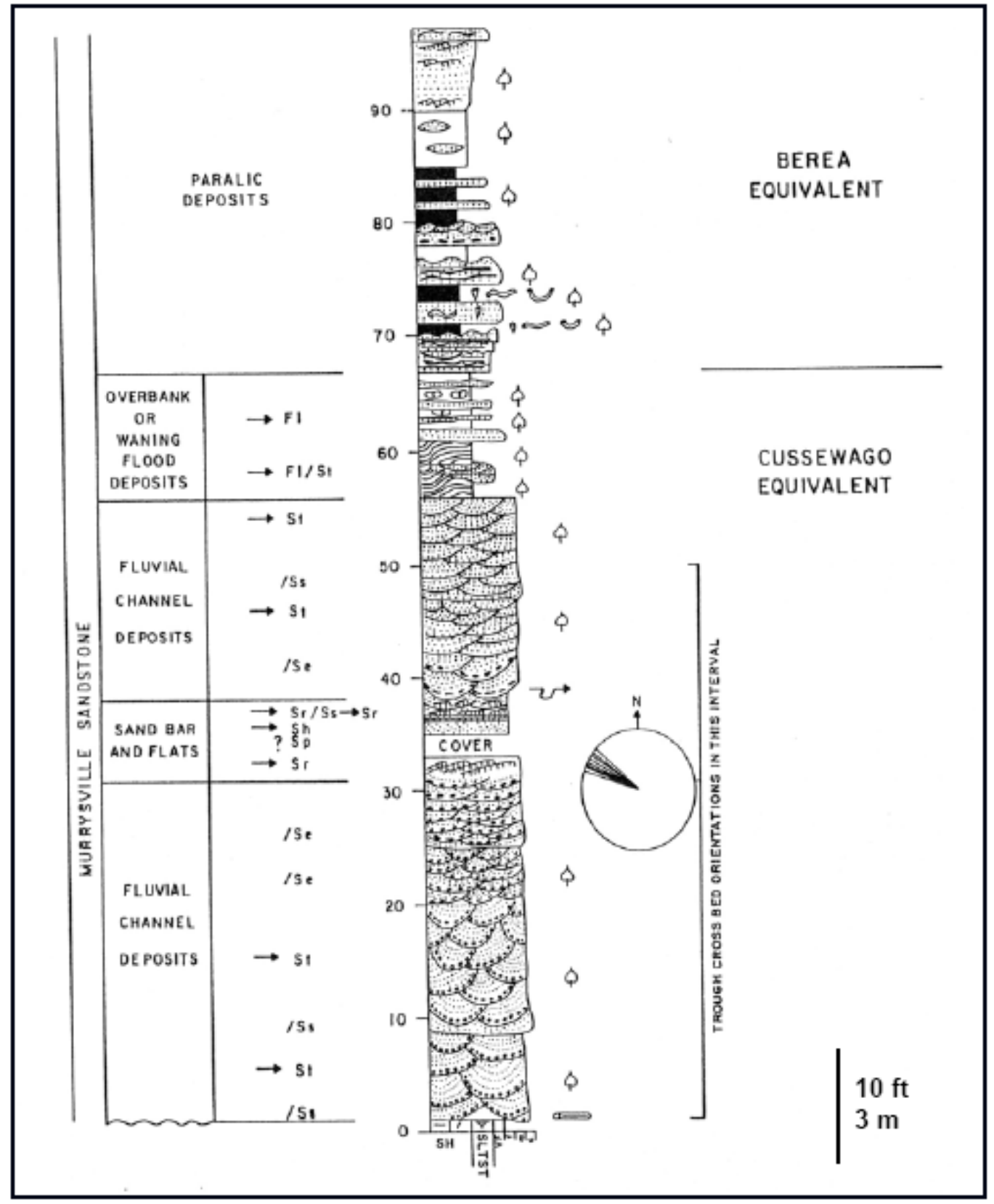

Figure 29 - Measured section of the Murrysville near Cramer, Pa. (Harper and Laughrey, 1989) 
Bjerstedt and Kammer (1986), in contrast, interpreted the Cussewago Sandstone in outcrops in West Virginia, Maryland, and eastern Pennsylvania as a marine-sand body. They interpret this nearshore sand to have been deposited during a brief but significant transgression, after which a lowstand, a marine sand sheet was deposited during shoreface retreat.

Edmunds et al. (1979) thought that the Cussewago was deposited during westward progradation of a coastal plain dominated by delta lobes. Maximum western progradation of the Catskill delta occurred in the Late Devonian when the shoreline was located to the west of the study area (Figure 3). Progradation was temporarily terminated by a marine transgression. The shoreline again advanced to the west in early Mississippian, and the Cussewago was deposited in a marine-shelf and lower delta-plain environment. Sediment was derived from the northeast and southeast. Depositional variation within the Cussewago Sandstone was controlled by deltaic switching (Edmunds et al., 1979).

Pepper et al. (1954) likewise interpreted the Cussewago as a deltaic deposit. The Cussewago Delta formed near the Ohio Bay and reached its peak westward progradation in northeastern Ohio (Figure 4). This delta was likely to be growing concurrently with the Red Bedford Delta that prograded south through present-day Ohio. The Cussewago Delta may have begun to form in Late Devonian time near its likely source of sediment in western Maryland and north-central Virginia. Pashin and Ettensohn (1995) studied the Cussewago in Ohio and adjacent states where they interpreted the Cussewago as fluvial deltaic. 


\section{Berea Sandstone $=$ Upper Murrysville}

Berea-equivalent sandstone, siltstone and shale at the Cramer outcrop (30 feet, 9.1 meters thick) are quite different from the underlying Cussewago Sandstone (Figure 29). Sedimentary structures include wave ripples, current ripples, parallel lamination, wavy, flaser, and lenticular bedding, shallow scours, and rip-up clasts. In addition, marginalmarine trace fossils (horizontal, vertical and U-shaped burrows) and plant debris are abundant (Harper and Laughrey, 1989). Based on the features the upper Murrysville sandstone was interpreted to have been deposited on an upper shoreface and/or tidal channel-flat (Harper and Laughrey, 1989). Marginal-marine trace fossils of Arenicolites,

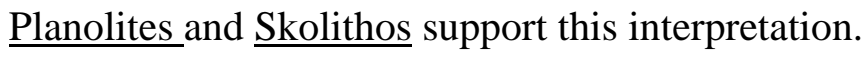

Tomastik (1996) recognized three facies of the Berea in the Appalachian basin. These are fluvial deltaic, shallow marine, and barrier island. (1) In my study area the facies was fluvial-deltaic. In Ohio, West Virginia and Pennsylvania, the presence of a fluvial-deltaic system is indicated by sand-filled channels that cut into the Bedford Shale. (2) Sheet sandstones represent the nearshore and coastal environments from Tomastik's (1996) shallow-marine facies. This second facies is present in Pennsylvania, Ohio, West Virginia, Virginia and Kentucky. The shoreline-sand bodies exhibit a coarsening-upward texture (Tomastik, 1996), and the scale of sedimentary structures also increases upward (Heald and Larese, 1974). The sand of the marine shelf was subject to wave and current action. (3) The third facies is the barrier-island sandstone with a marine fauna. This marine facies is located to the southwest of my study area in Ohio, and Tomastik (1996) recognized it as having a different trend from the fluvial-deltaic facies. This last facies 
comprises the Second Berea situated 30 feet below the Berea in Ohio (Tomastik, 1996) and is most likely equivalent to the Cussewago.

Pepper et al. (1954) believed the Berea Sandstone of Ohio had a northwestern source. The lower part of the Berea is composed of braided-stream deposits, and the upper part formed mostly on a shallow shelf as the epicontinental sea began to transgress in Berea time.

\section{Sedimentary Environment at Snyder Unit \#3 Well}

Quartzarenites, such as those in lower Murrysville, are most commonly sourced from preexisting sandstones (Blatt, 1992; Bloch, 1994). Suttner and et al. (1981) agreed stating that first cycle quartzarenites would be rare. It would take a "unique combination of extreme conditions” to produce such rocks (Suttner and others, 1981). The conditions required would be an arid climate, high relief and high sedimentation rate. Johnsson and others (1988) disagreed, believing that these conditions are not unique and first cycle quartzarenites can form in diverse tectonic settings. Harper and Laughrey (1989) suggested a recycled-orogen provenance for the Murrysville sediments. Recycled-orogen sands are rich in quartz and sometimes sedimentary/metasedimentary lithics (Dickinson and Suczuk, 1979, Blatt, 1992).

Litharenites, such as those of the upper Murrysville, have a wider provenance than quartzarenite, usually a large drainage basin with diverse bedrock (Pettijohn, 1975). This rock type therefore is likely to be deposited by large rivers systems. In my study the quartz content decreases and lithics increase upsection, hinting that the drainage area may have enlarged over time and covered a more diverse bedrock. Another possibility is that the energy of the stream decreased. As the energy level decreased, mechanical 
weathering would also decrease. This reduction would result in fewer lithics being destroyed.

The abundance of metamorphic lithic fragments in the Murrysville suggests that much of the sediment was from a previously metamorphosed orogen. In addition to the varieties of metamorphic quartz, metamorphic rock fragments and micas, grains include sedimentary chert and shale rock fragments, averaging 6.25 percent of the rock volume. One volcanic rock fragment is also present. The source area therefore must have contained a mix of different rock types. The source area was a substantial distance to the southeast (Pepper and others, 1954) and would have required an efficient transport mechanism. An alluvial environment of large braided rivers would be capable of transporting sediment great distances (Harper and Laughrey, 1989). Cross sections and maps published by McDaniel (2006) show the Murrysville to be widespread and thick, which supports a braid-delta interpretation. The Murrysville commonly displays a blocky shaped log response (Figure 30), characteristic of braided channels (Coleman \& Prior, 1981, Pettijohn and others, 1987). McDaniel (2006) recognized a facies change in western Westmoreland County from a channel sequence to a braided-delta that was influenced by the Rome Trough basement fault which runs through the area. Other depositional environments were inferred from the data such as interfluvial deposits, an abandoned feeder stream, and abandoned delta lobes (Figure 31) (McDaniel, 2006). Chamosite, which is also present in a few samples, is commonly authigenic, forming in shallow-marine environments (Fuchtbauer, 1983). Chamosite is thought to form in reducing environments that are iron rich. 


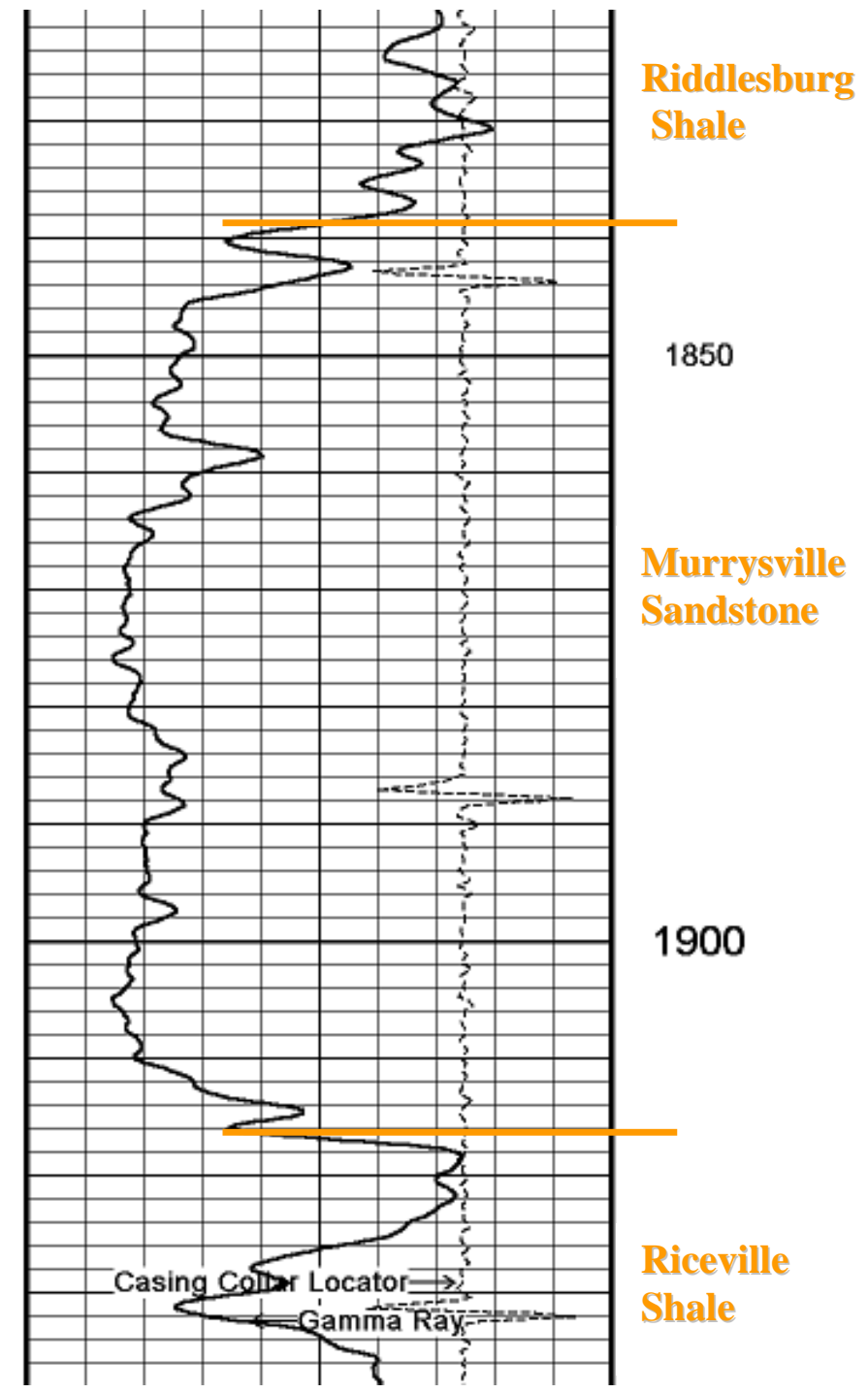

Figure 30 - Gamma ray curve (by Schlumberger during coring) from the Snyder Unit \#3 showing the Riceville Shale, Murrysville sandstone and Riddleburg Shale. 


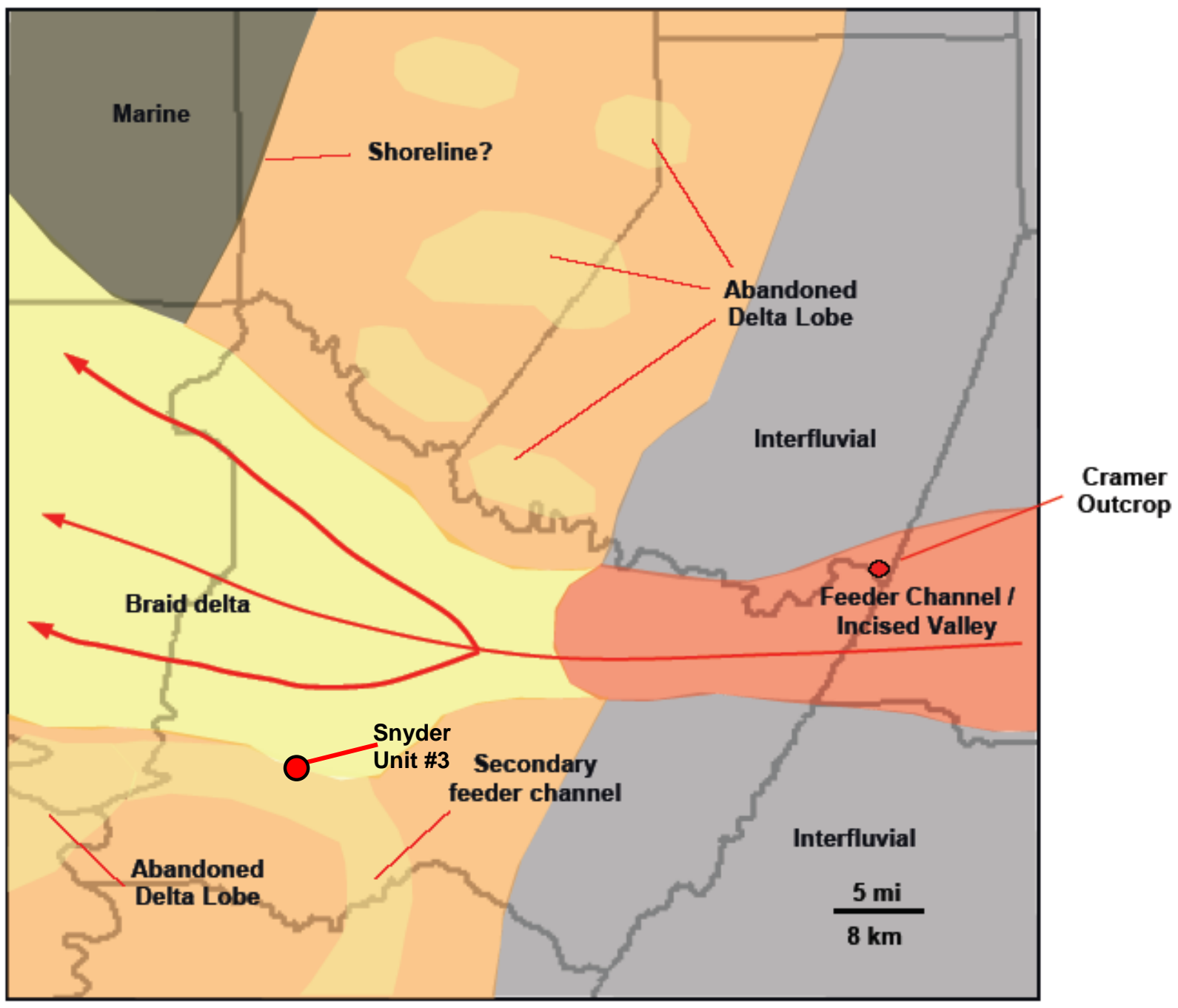

Figure 31 - Paleogeographic map showing channel and braided-delta facies during Murrysville time. Also shown is location of Snyder \#3 well (modified from McDaniel, 2006) 
In the Snyder well the mean grain size in the Murrysville decreases upward. Figure 32 shows this change in grain size in the Snyder well. The base of the formation is marked by conglomerates with grain size averaging $2.50 \mathrm{~mm}$, fining up to $0.23 \mathrm{~mm}$ at the top. This fining-upward sequence is typical of a braided stream deposit associated with an upper delta plain (Coleman and Prior, 1981; Cant, 1982). Fining-upward sequences are associated with a decrease in energy associated with shallower flow. Braided channels are dominated by a large amount of sediment in the bedload, high variations in water discharge and high gradient. As the grain size becomes finer upward in the section, sublitharenites become the dominant rock type (Figure 19 and 32).

At 1855 and 1865 feet (565.4 to 568.5 meters), the Murrysville contains shale interbeds. Cant (1982) reasoned that lateral migration of channels is the cause of shales encased in coarser sediments. Braided rivers are laterally unstable because floodplain banks are thinner, less cohesive and are more easily erodable than other rivers. High discharge peaks and steep slopes increase their eroding power. During times of flooding, erosion occurs on the floodplain. The sediment from the floodplain is later deposited when the flooding has ceased. 
Figure 32 -- Mean Grain Size Vs Depth

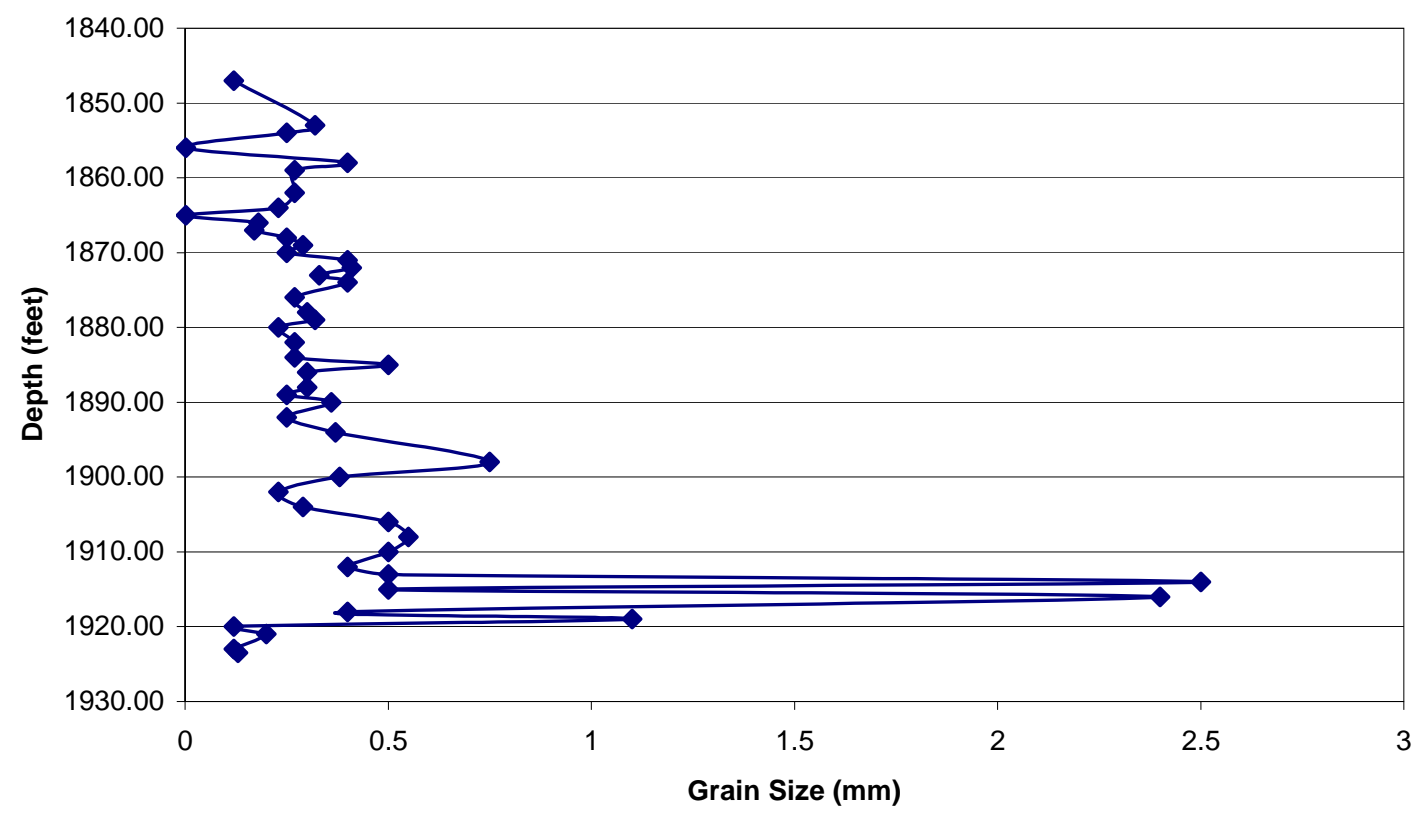




\section{DIAGENETIC PROCESSES - COMPACTION AND CEMENTATION}

\section{Compaction}

The term diagenesis was coined by von Gümbel in 1888 and has been used in many ways since (Pettijohn and others, 1987). Workers accept varying processes to be included in diagenesis. Most restrict diagenesis to processes that occur after deposition, including lithification, but excluding metamorphism.

Compaction is one of the first diagenetic processes to occur and is the dominant mechanism of porosity reduction (Bloch, 1994). Compaction is a function of grain type and the burial history of the area (Worden et al., 2000). Rotation, translation, fracturing and plastic deformation are all functions of compaction and result in a loss of porosity (Rittenhouse, 1971; Pettijohn and others, 1987). In a study by Smosna (1989) on lithic sandstones in Alaska's North Slope, he found that 75 percent of the compaction was the result of rearrangement of grains at a depth shallower than 550 to 800 meters.

An index of compaction can be calculated for the Murrysville sandstone by adding the percentage totals for quartz grains, chert, feldspars, lithic rock fragments, micas, all accessory minerals, and secondary porosity (that is, vanished grains) (Bloch, 1994). This sum equals the percent of original framework grains in the rock (Smosna and Bruner, 1997). Coogan (1970) calculated a compaction index for oolitic grainstones in the form of Packing Density. Packing Density is measured by $x P D \%=\Sigma g i / T L x 100$, where $x P D$ is the arithmetic mean of the measurements made on thin section, $T L$ is the total length of all transverses and gi is the grain intercept size (Coogan, 1970). Rocks that have undergone greater compaction should have a greater grain intercept size than rocks which are uncompacted. 
The lowest values of our compaction index in the Murrysville range from 62 to 69 percent. It is assumed that these lowest values represent the percent of framework grains after minimal physical compaction, that is, sand with moderate to poor sorting, a small volume of matrix, small volume of ductile lithics, in a somewhat open packing. For comparison, perfectly sorted spheres, rigid and with no matrix and arranged in an open packing, have a total grain volume near 60 percent (Rittenhouse, 1971). The increase in compaction index of Murrysville samples from 69 to 88 percent (Figure 33) represents a progressively closer packing of the framework grains under conditions of greater compaction.

Figure 33 shows that as physical compaction proceeded, minus cement porosity (porosity that the sand had before any chemical cement) decreased ranging from 11 to 31 percent porosity. Porosity decreases as all grains move closer together. Physical compaction can eliminate porosity in many sandstones that are rich in ductile grains (Pettijohn et al, 1987; Bloch, 1994). Rigid grains, by contrast, provide a more stable framework, helping to retard compaction and preserve primary porosity. Most of the lithic fragments in the Murrysville are metamorphic (3.71\%); however, some are sedimentary $(0.85 \%)$. These fragments are ductile and usually lead to greater compaction. In the Murrysville the ductile grains are most often surrounded by rigid grains and are therefore protected as recognized by Rittenhouse (1971) and Worden et al, (2000). The lithics present are usually slightly squished, not many are greatly deformed. Compaction is also dependent on grain size. The amount of compaction can be expected to decrease as grain size decreases due to the increased number of grain contacts which provide a more stable framework (Bloch, 1994). This is true in the Murrysville 
where compaction increases to 88 percent as grain size increases to maximum of $2.5 \mathrm{~mm}$ (Figure 34). Matrix also helps to retard compaction by occupying space between framework grains. As matrix increases to 12.3 percent in one sample the compaction index decreased to 61.7 percent (Figure 35). The Murrysville has seemingly undergone little compaction as shown by the fact that most grains have either floating or point contacts (Figure 22). Very few grains have sutured contacts that are indicative of pressure solution. Microstylolites, however, are present and show a late history of chemical compaction (Tucker, 1981). 
Figure 33 -- Compaction Index vs Minus Cement Porosity

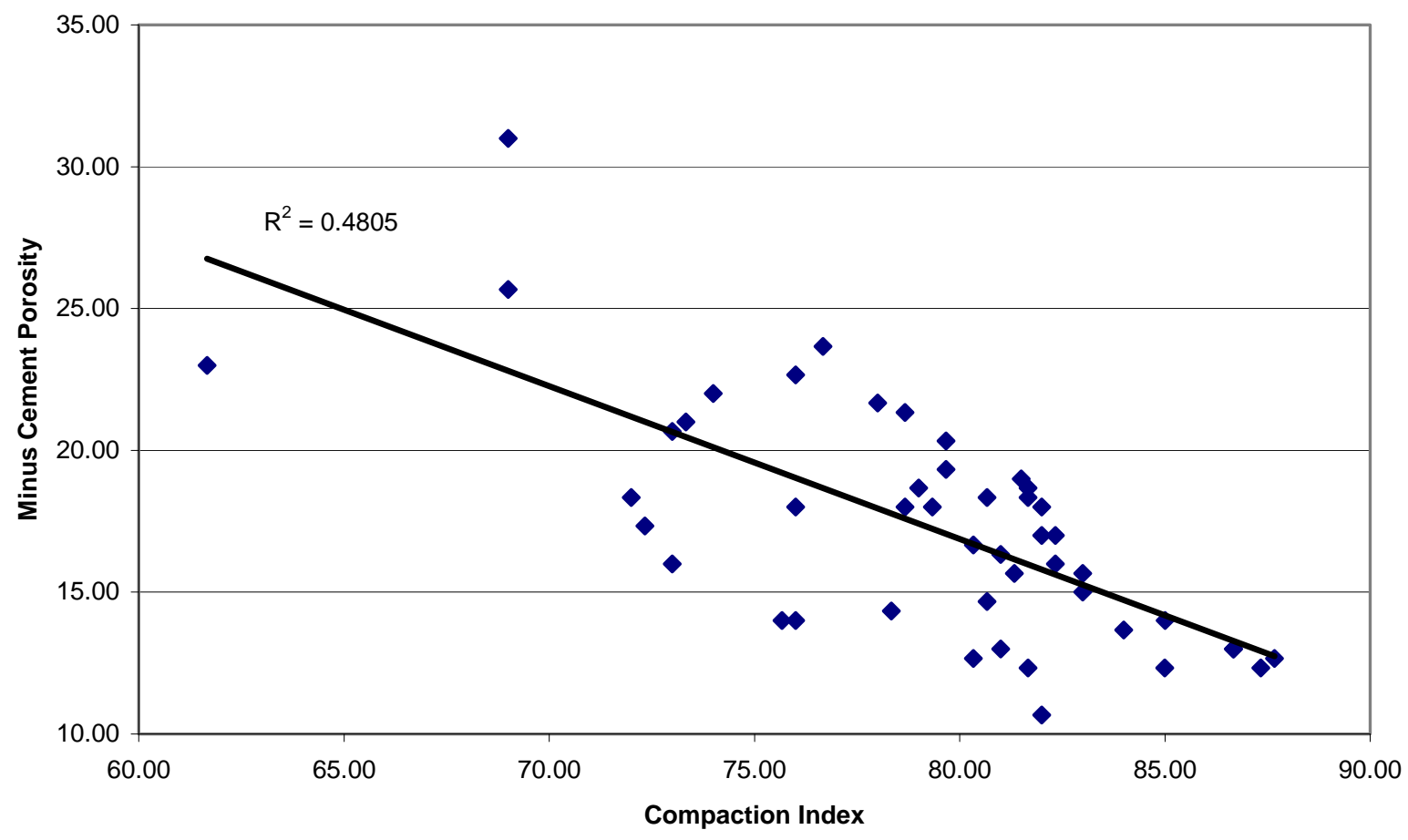

Figure 34 -- Compaction Index vs Grain Size

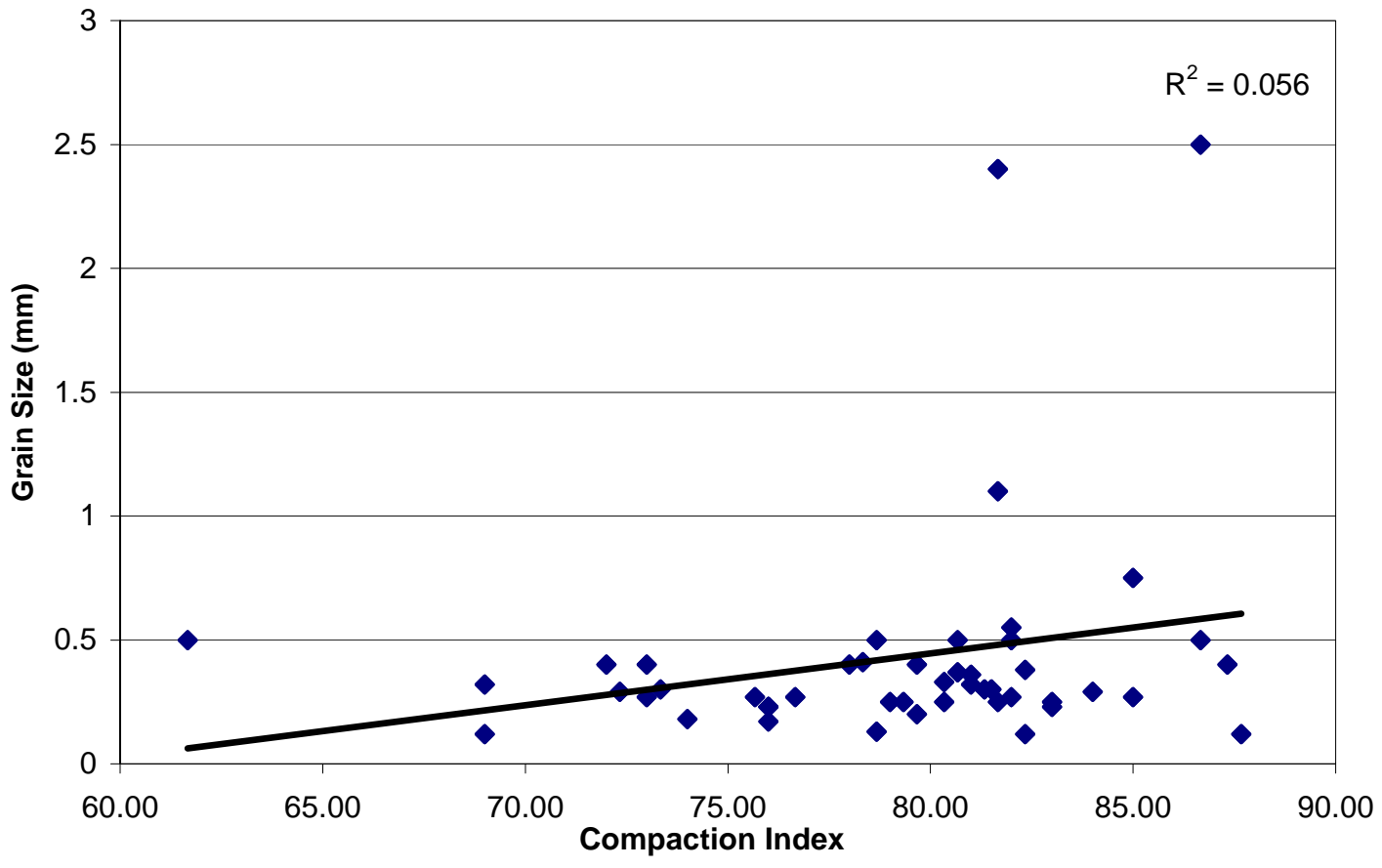


Figure 35 -- Compaction Index vs Matrix Content

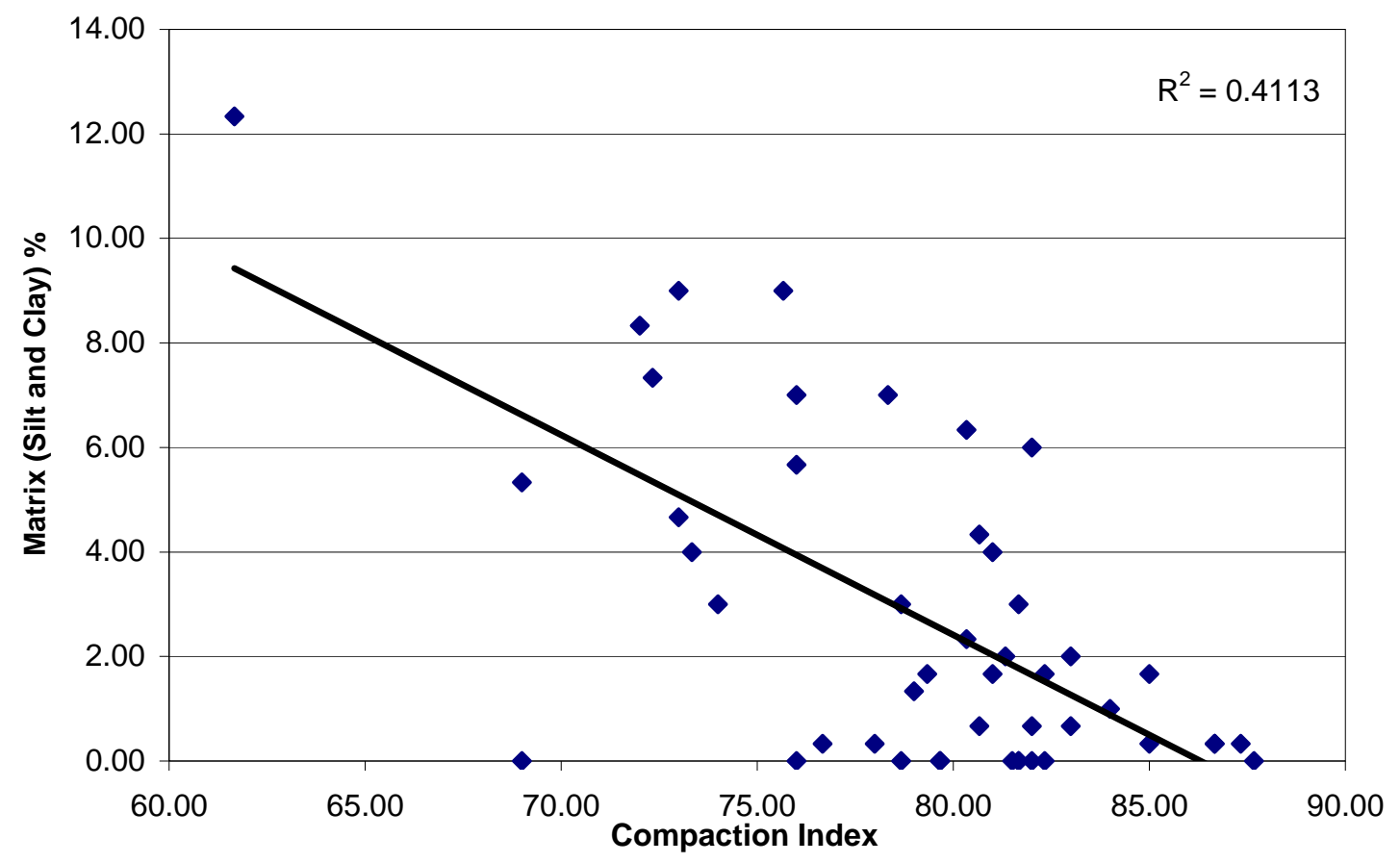




\section{Cementation}

The most common form of silica cement in sandstones is quartz overgrowths. This involves the secondary enlargement of quartz grains by optically continuous overgrowths. This syntaxial overgrowth commonly gives the grain euhedral crystal faces (Tucker, 1981). The transformation of montmorillonite to illite can account for much silica in sandstone pore waters (Towe, 1962; Pettijohn, 1987). As temperature increases due to burial, montmorillonite transforms to illite and silica is released (Tucker, 1981). This transformation occurs between 70 to $95^{\circ} \mathrm{C}$, at depths of 2 to $3 \mathrm{~km}$. In addition, the dissolution of feldspars can supply silica for cement (Pettijohn and others, 1987). Weathering of feldspars by meteoric ground water is a major source of dissolved silica. The silica may precipitate as quartz as fluids flow down the flow direction in the same sandstone or other formations. A wet climate is imperative for this method to work. Alternatively connate water, sea water trapped in pores, can also be a source of silica. The connate water is present in surrounding shales which are initially porous, and as they compact the connate water leaves the formation (Pettijohn, 1975). However, the amount of silica in connate water is negligible and cannot be wholly responsible for quartzcemented sandstones. A last source for silica comes from within the sandstone itself. Solution of silica at grain contacts and precipitation in the voids could be responsible for quartz-cemented sandstones (Pettijohn, 1987) and the Murrysville is no exception.

Quartz cement is the most common cement in the Murrysville sandstone. Figure 36 shows the amount of quartz cement as a function of depth. Quartz cement averages 6.4 percent and ranges from 2.7 to 20.7 percent. Quartz cement is more abundant at the top where it reaches 20.7 percent and bottom of the Murrysville where the maximum is 
Figure 36 -- Quartz Cement Vs Depth

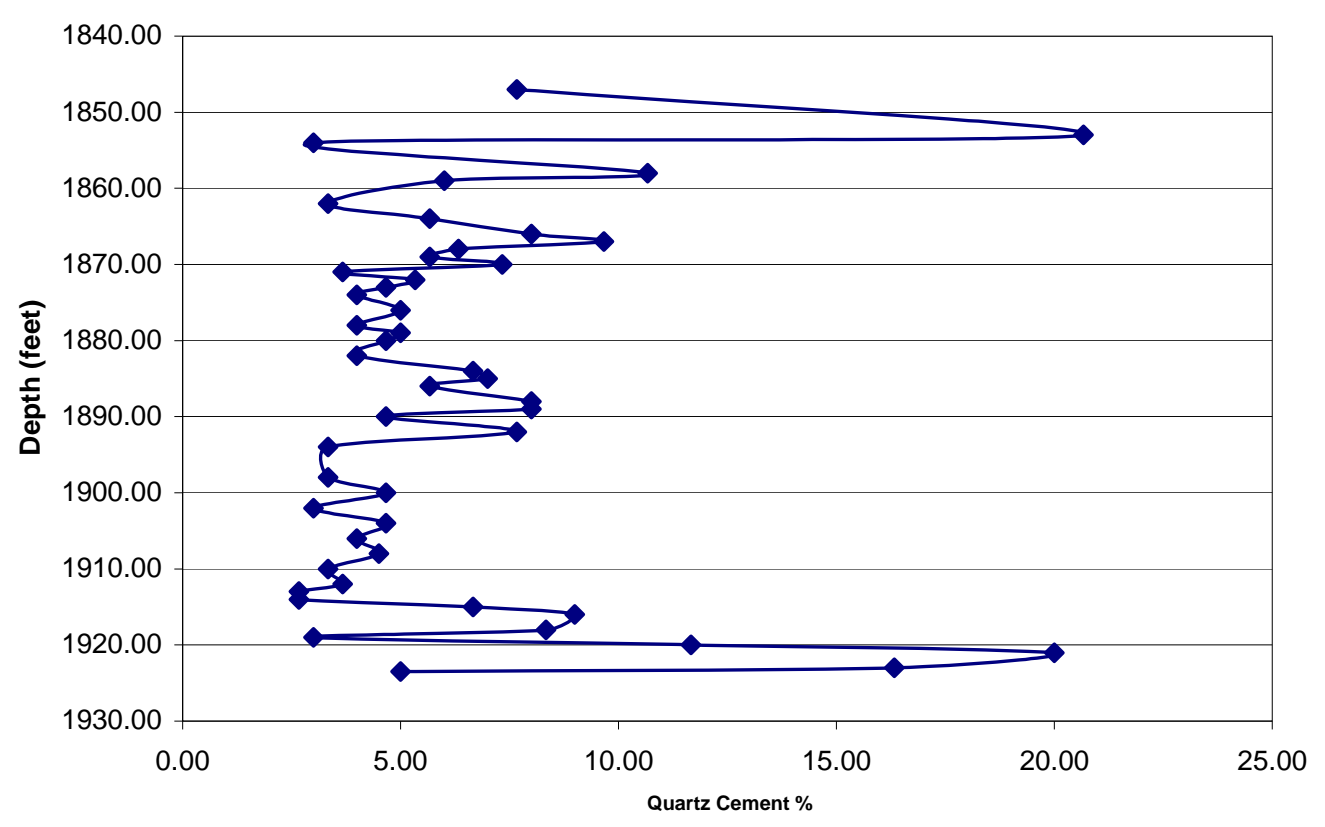


20 percent. The top and base of the Murrysville is in contact with the Riddlesburg and Riceville Shales respectively. This distribution suggests that the source of dissolved silica for cement was the adjacent shales during dewatering and clay-mineral transformation.

Though not as common as quartz cement, chlorite rims were the first cement to form, as shown by the fact that the chlorite is never found on top of any other type of cement. Chlorite rims formed independent of grain size or grain type. In some cases the chlorite rim surrounding a grain has been broken or is discontinuous, and most often quartz or calcite cement precipitated on the enclosed grain filling the gap. These examples, too, indicate that quartz and carbonate cements post-date the chlorite cement. Where chlorite rims are present, as little as 1 percent, quartz cement generally is not greater than 10 percent (Figure 37), therefore preserving more primary porosity. Some authors propose a chemical theory as to why quartz cement is not prevalent in chlorite-coated sandstones. This theory states that understaturation is the cause for lack of quartz cement (Billault et al., 2003). Others believe the issue is more of a physical cause. Chlorite rims are often the first cement to form and inhibit quartz cement by isolating quartz surfaces from pore water and preventing nucleation (Heald and Larese, 1974; Ehrenberg, 1993). A study by Billault et. al. (2003) found that the lack of quartz cement was due to the difficulty of epitaxial growth of secondary quartz into interparticle space at the base of chlorite coatings. Chlorite coatings isolated surfaces on detrital quartz and reduced the number of growth sites for authigenic quartz to nucleate (Ehrenberg, 1993). However, continuity of the coatings is important in inhibiting quartz cement. 
Figure 37 -- Chlorite Rims vs Quartz Cement

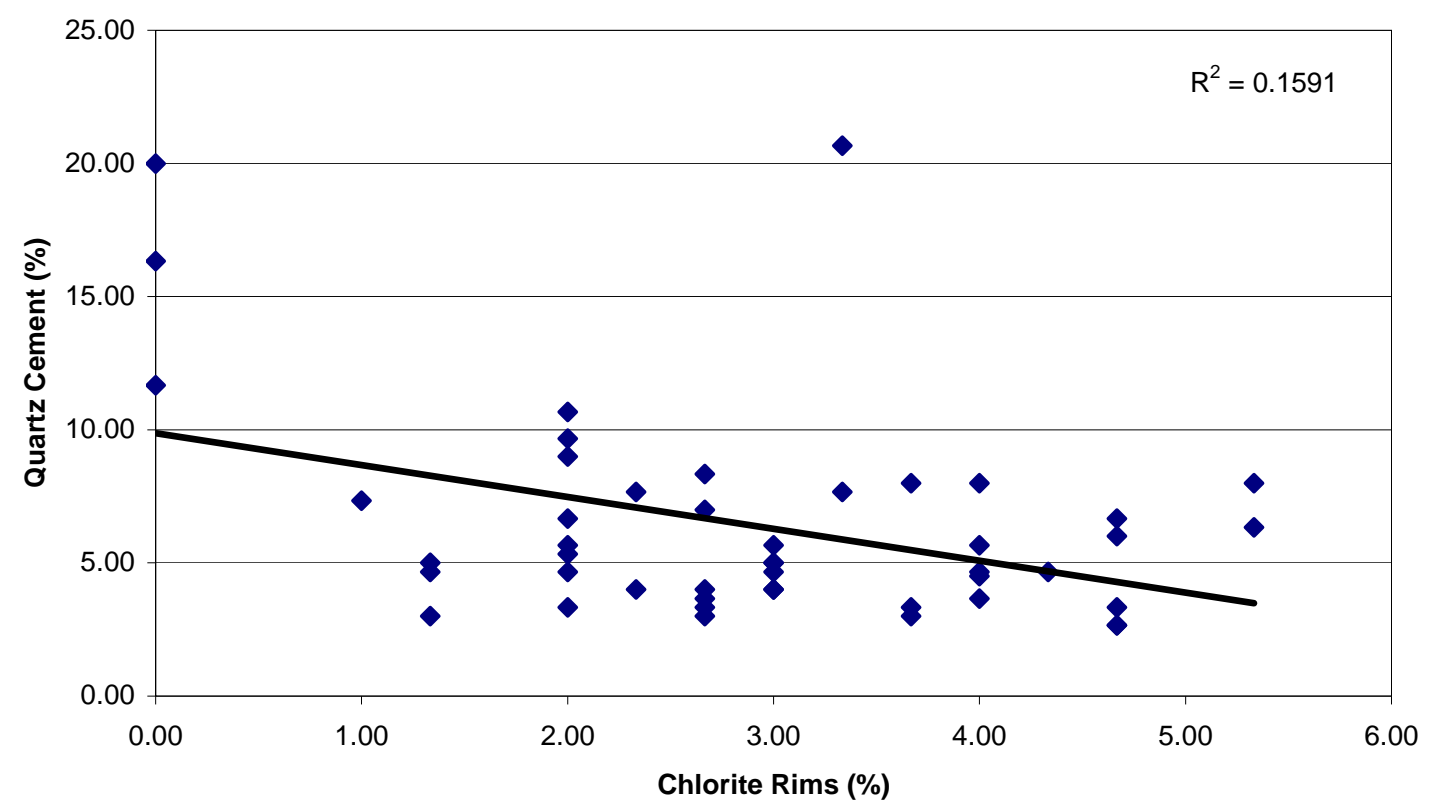


Chlorite rims are more prevalent towards the top of the Murrysville sandstone (Figure 38). The possible sources of chlorite are the same as sources for silica: clay transformation or connate water from the overlying Riddlesburg Shale. Chlorite rims formed early in the diagenetic process; therefore, connate water from the Riddlesburg Shale more likely provided the chlorite instead of clay transformation which would have happened later in the diagenetic sequence. Chlorite formation depends on an iron-rich precursor. Chlorite has been interpreted to form by alteration of mixed-layer iron-rich clays and kaolinite during burial and also in magnesium-rich environments (Wilson and Stanton, 1994). In the Murrysville chlorite rims formed early, ruling out clay transformation which would have occurred later in the diagenetic sequence. Chlorite or an iron-rich clay precursor must have been present. The source of iron needed for the formation of chlorite cement is commonly iron-rich clays that form in marine environments influenced by fluvial discharge that is high in iron that has been derived from weathering (Ehrenberg, 1993).

Calcite cement in the Murrysville comprises an average of 1.6 percent rock volume and ranges from being absent to 12 percent. Calcite cement usually precipitates as one of two types: poikilotopic crystals and drusy spar. Poikilotopic crystals are large single crystals that engulf many grains. Drusy calcite consists of equant crystals progressively filling single pores between grains (Tucker, 1981). In the Murrysville calcite cement is poikilotopic (Figure 17) and precipitated as large crystals that are optically continuous and extend through many pores.

Calcite is frequently an early cement in sandstone, and most often the first cement (Tucker, 1981). In other sandstones, however, calcite is a late precipitate (Tucker, 1981). 
Figure 38 -- Chlorite Rims Vs Depth

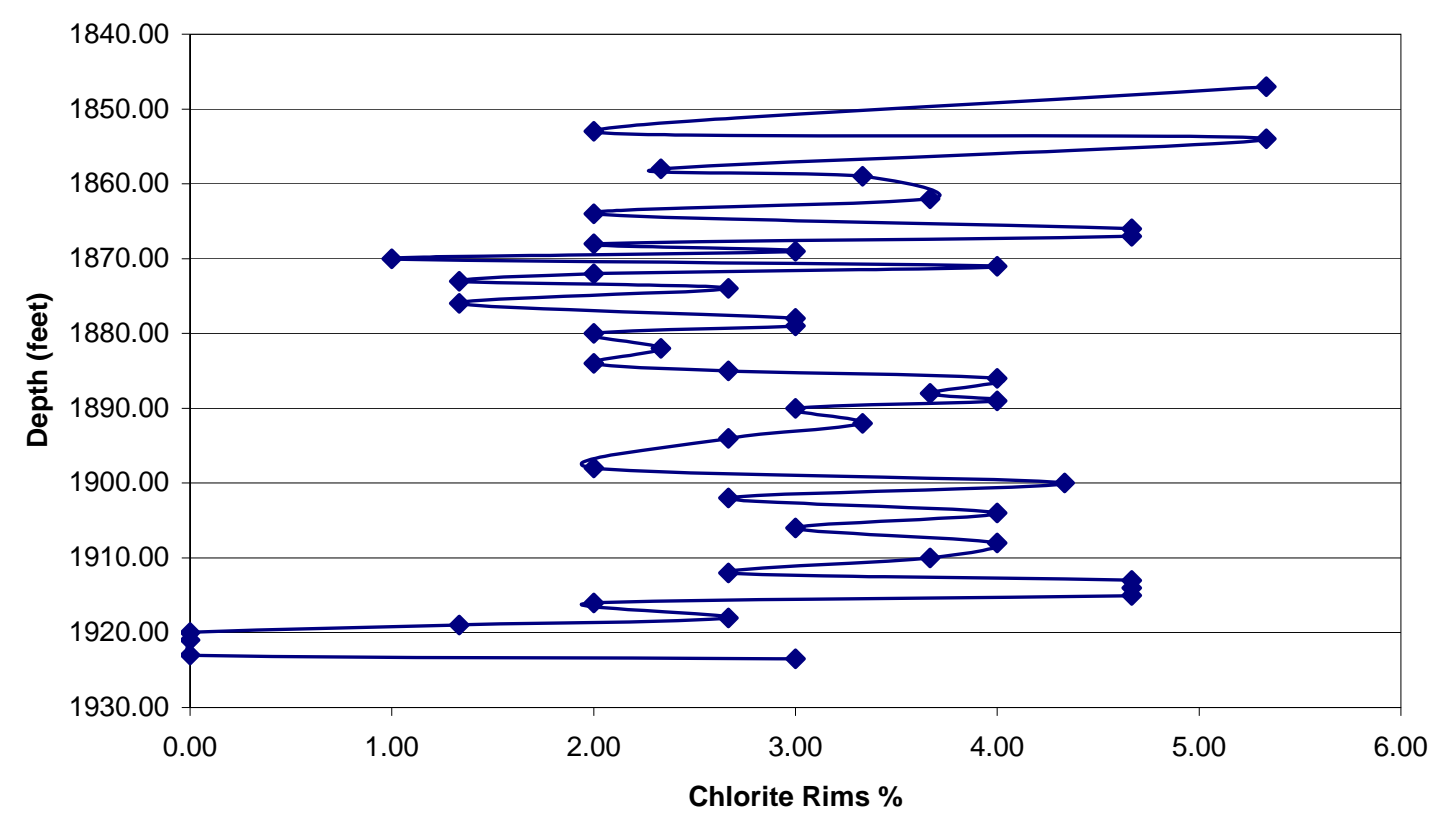


In the shallow subsurface the carbonate ion is available through evaporation of groundwater. At depth, carbonate precipitation is caused by an increase in $\mathrm{pH}$ and/or temperature (Tucker, 1981). In the Murrysville calcite cement is more abundant at the top of the formation comprising 12 percent rock volume as seen in Figure 39, suggesting that the source of $\mathrm{CaCO} 3$ was the overlying Riddlesburg Shale.

Siderite occurs as a minor cement and is locally poikilotopic. It is present in only 9 samples and is never more than 1 percent of the rock volume. Siderite cement is ironrich and common in nonmarine and organic rocks in reducing environments (Tucker, 1981). Siderite is inhibited from forming in marine environments because $\mathrm{Ca}++$ reacts preferentially with bicarbonate at normal marine concentrations (Matsumoto and Iijima, 1981). Siderite forms through the combined effects of iron reduction and bacterial methanogenesis of organic carbon. Only in a nonsulfide environment can iron be precipitated as siderite (Berner, 1991). A sulfide deficient environment can be produced by the activity of sulfur-reducing bacteria (Berner, 1991). Siderite present indicates that the Murrysville was most likely deposited in a nonmarine environment. Siderite is inhibited from forming in marine environments because $\mathrm{Ca}++$ reacts preferentially with bicarbonate at normal marine concentrations. The $\mathrm{Fe}++/ \mathrm{Ca}++$ ratio in normal marine waters is two orders of magnitude too small to permit siderite precipitation (Matsumoto, 1981).

Both calcite cement and siderite cement formed after other diagenetic processes had ceased. The author is not sure if there was a particular order to the calcite and siderite cements or if they were depositing concurrently. In sample 1900 the chlorite coating, still intact, surrounds the ghost of a grain (Figure 40). The moldic pore where 
the grain once was is now filled with calcite cement, after chlorite precipitation and grain dissolution. In sample 1912 calcite cement lies on top of the chlorite rims showing that it was deposited later. 
Figure 39 -- Calcite Cement vs Depth
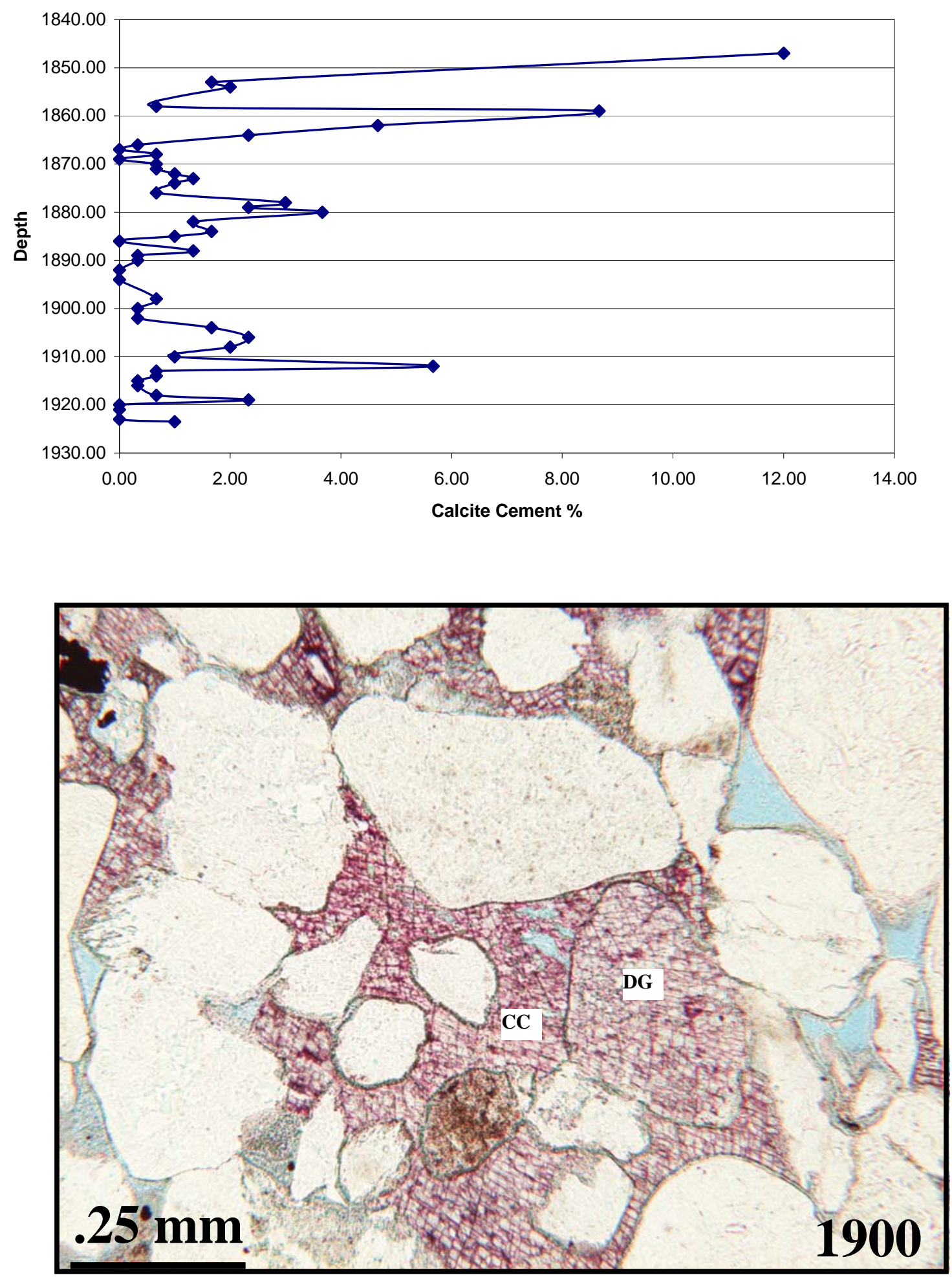

Figure 40 - Calcite cement (CC) filled the pore left by a dissolved grain (DG). The chlorite coating is still intact. 


\section{Timing}

The overall diagenetic sequence for the Murrysville compares well with other sandstones. Helmold and van de Kamp (1984) published a study showing general diagenetic stages for Paleogene sandstones of the Santa Ynez Mountains, California. In the shallow subsurface, pore-lining clays, compaction, dissolution and calcite cementation all occurred. Pore-lining clays occurred only in an early stage, whereas compaction and dissolution continued into the deep subsurface. Calcite cementation ceased during burial but continued again during the latest stage of burial. In the deep subsurface quartz overgrowths began while compaction and dissolution were still occurring.

In four reservoirs studied by Billault et al. (2003) all showed chlorite coatings and compaction to be early in the diagenetic sequence. Two of the sandstones, the M'Bya and Halternbanken reservoirs, contained calcite cement which precipitated early before quartz overgrowths and feldspar dissolution.

These patterns of diagenesis are similar to the Murrysville in that compaction and the formation of pore-lining clays occurred early (Figure 41). Compaction was the first diagenetic event to occur and continued into the middle stage of diagenesis. Chlorite rims formed after the sand grains had come into contact and was the first cement to precipitate. Evidence of this timing can be seen along grain contacts where no chlorite rims are present (Figure 14 and 25). Chlorite rims predate quartz and calcite cementation since no chlorite rims precipitate on either cement (Figure 14). The most notable differences in the Murrysville to the reservoirs mentioned above is the timing of calcite cement. In studies by Helmold et al. (1984) and Billault et al. (2003) calcite formed early 


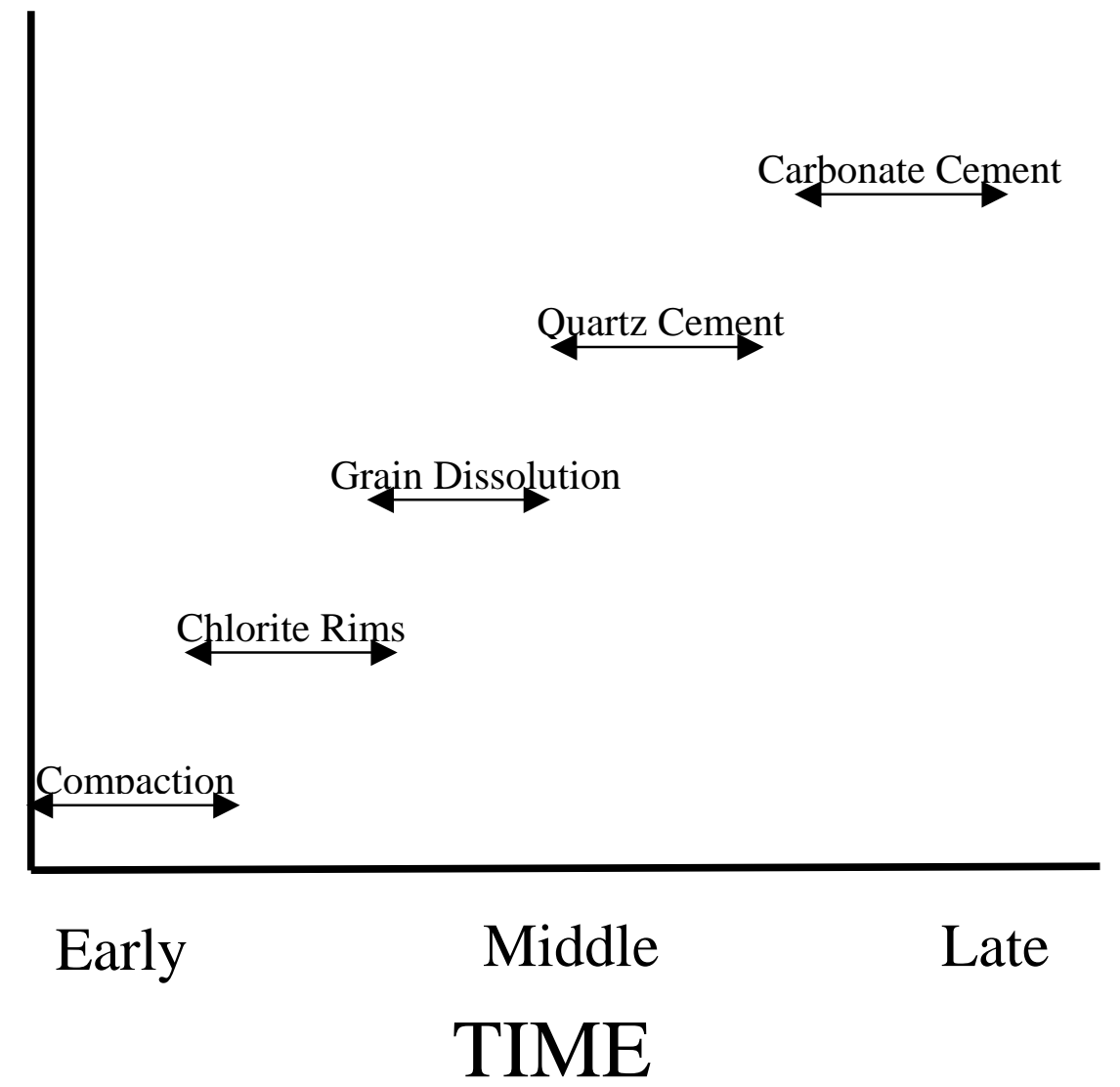

Figure 41 - Order of compaction and cementation 
in the sequence. Although in the Paleogene sandstones calcite also formed late. In the Murrysville quartz cement was the second cement to form and calcite cement precipitated only in the latest stage of diagenesis. The following observations show that calcite cement came after compaction, chlorite coating and quartz cementation. Figure 11 shows that calcite was certainly formed after compaction. Evidence is present in many samples where calcite cement overlies syntaxial quartz overgrowths (e.g., Figure 17) and fills dissolution molds of pre-existing grains. Thus, by the use of cement stratigraphy, I have established the age relationship of these two minerals—quartz pre-dates the calcite and siderite. Figure 40 shows that calcite cement precipitated after the chlorite cement and after dissolution. 


\section{DIAGENESIS - POROSITY DEVELOPMENT}

The factors affecting porosity and permeability occur during deposition and diagenesis (Bloch, 1994). Depositional controls include grain size and sorting, whereas diagenetic controls include chemistry, temperature, pressure and time. The diagenetic development of a sandstone can be divided into three main categories: porosity reduction, porosity preservation, and porosity increase (Heald and Larese, 1974). Chemical processes that reduce porosity include cementation, pressure solution and dissolution. Physical processes associated with compaction are rearrangement, plastic deformation, and fracturing (Wilson and Stanton, 1994). Early cementation can preserve porosity by retarding compaction. Dissolution of grains and cements produces secondary porosity.

Primary porosity in sandstones is mostly interparticle porosity and is dependent upon the textural maturity of the sandstone (Tucker, 1981). Primary porosity increases where grains are better sorted and more angular with low amounts of clays.

Primary porosity is greatly reduced by physical compaction, especially of sandstones that are rich in ductile grains. Where few ductile grains are present, stabilization of the rock framework by rigid grains can preserve primary porosity. Although some initial porosity can be lost by cementation, compaction and grain rotation, some primary porosity can be preserved in the rock.

Allogenic and authigenic clay minerals can also reduce porosity and permeability (Bloch, 1994). However, small amounts of these clays can seriously reduce permeability without affecting porosity (Wilson and Stanton, 1994). 
Chlorite coatings can prevent secondary cements from occluding the pores by isolating grain surfaces and reducing the number of available growth sites, also preserving primary porosity. Clay coatings can also retard the mechanisms of porosity reduction and cementation.

If compaction is not great, primary porosity can be preserved allowing leaching fluids to enter the sandstone to create secondary porosity. Secondary porosity in clastic rocks is most often formed by dissolution of soluble grains and/or cements, commonly carbonate minerals and feldspars (Heald, 1974; Schmidt and McDonald, 1979).

Secondary porosity includes moldic porosity, intragranular porosity and fracture porosity. Schmidt and McDonald (1979) stated that at least one-third of total sandstone porosity is secondary. Studies by Schmidt and McDonald (1979), Surdam et al. (1987), and Shanmugam (1988) recognized enhancement of porosity by dissolution. Other authors, however, have stated that secondary porosity does not always mean enhanced porosity (Bjorlykke, 1984; Bloch, 1994). Bloch (1994) argued that porosity increase by dissolution of minerals is offset by a similar volume decrease by precipitation of pore filling cements using the products from dissolution. This process is known as redistribution and has little or no effect on the overall porosity. Bloch (1994) recognized that unusually high secondary porosity can be found where certain parameters coexist. High secondary porosities in the Upper Jurassic Norphlet Formation in New Mexico are explained by dissolution of early cements, dissolution of detrital grains, chlorite rims which prevent nucleation of quartz overgrowths, lack of early cements, and inhibition of cementation due to hydrocarbons and geopressuring (Bloch, 1994). 
Dissolution by meteoric water normally starts at shallow depths during eogenesis (Schmidt and McDonald, 1979). During this stage, carbonate including siderite, dolomite, calcite and aragonite is most commonly leached (Schmidt and McDonald, 1979). For dissolution to occur, the water must be undersaturated. As dissolution proceeds the water will become supersaturated which will allow for precipitation (Bloch, 1994). Most secondary porosity is created during mesogenesis, and can be attributed to the dissolution of minerals, mostly carbonates. Shanmugam (1988) stated that feldspar dissolution does not enhance reservoir quality, because of the immobility of aluminum; the products of feldspar dissolution precipitate in nearby pores as kaolinite.

The lack of compaction in the Murrysville is significant. The lack of compaction led to increased primary porosity and greater permeabilities. The Murrysville sandstone is also not well cemented. Only a few samples at the base and a few samples capping the unit can be considered well cemented (Figure 42). Primary porosity is present in the Murrysville sandstone as intergranular porosity, usually triangular in shape. Primary porosity is plotted against quartz cement in Figure 43 and shows that if quartz cement is greater than 10 percent, essentially no primary porosity remains. Primary porosity averages 6 percent although values change dramatically throughout the section, ranging from 0.33 percent to12.3 percent. Compaction did not destroy the primary porosity because of the low amounts of ductile grains and lack significant compaction (Figure 44).

Most detrital grains in the Murrysville sandstone are coated with chlorite needles perpendicular to the grain, which have prevented extensive cementation and preserved primary porosity, thus more chlorite, more porosity (Figure 45). Chlorite rims started to 
Figure 42 -- Quartz and Calcite Cement vs Depth

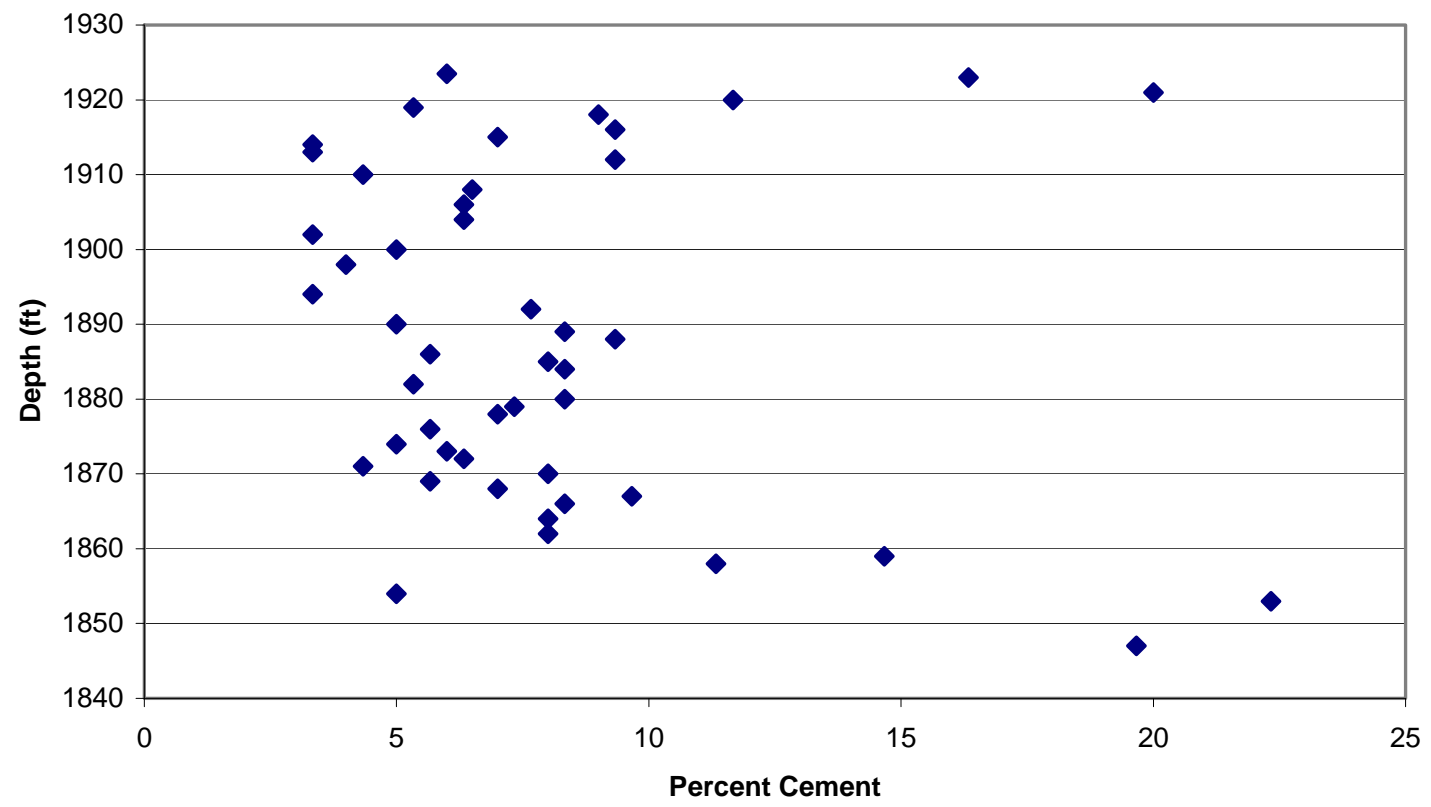

Figure 43 -- Primary Porosity Vs Quartz Cement

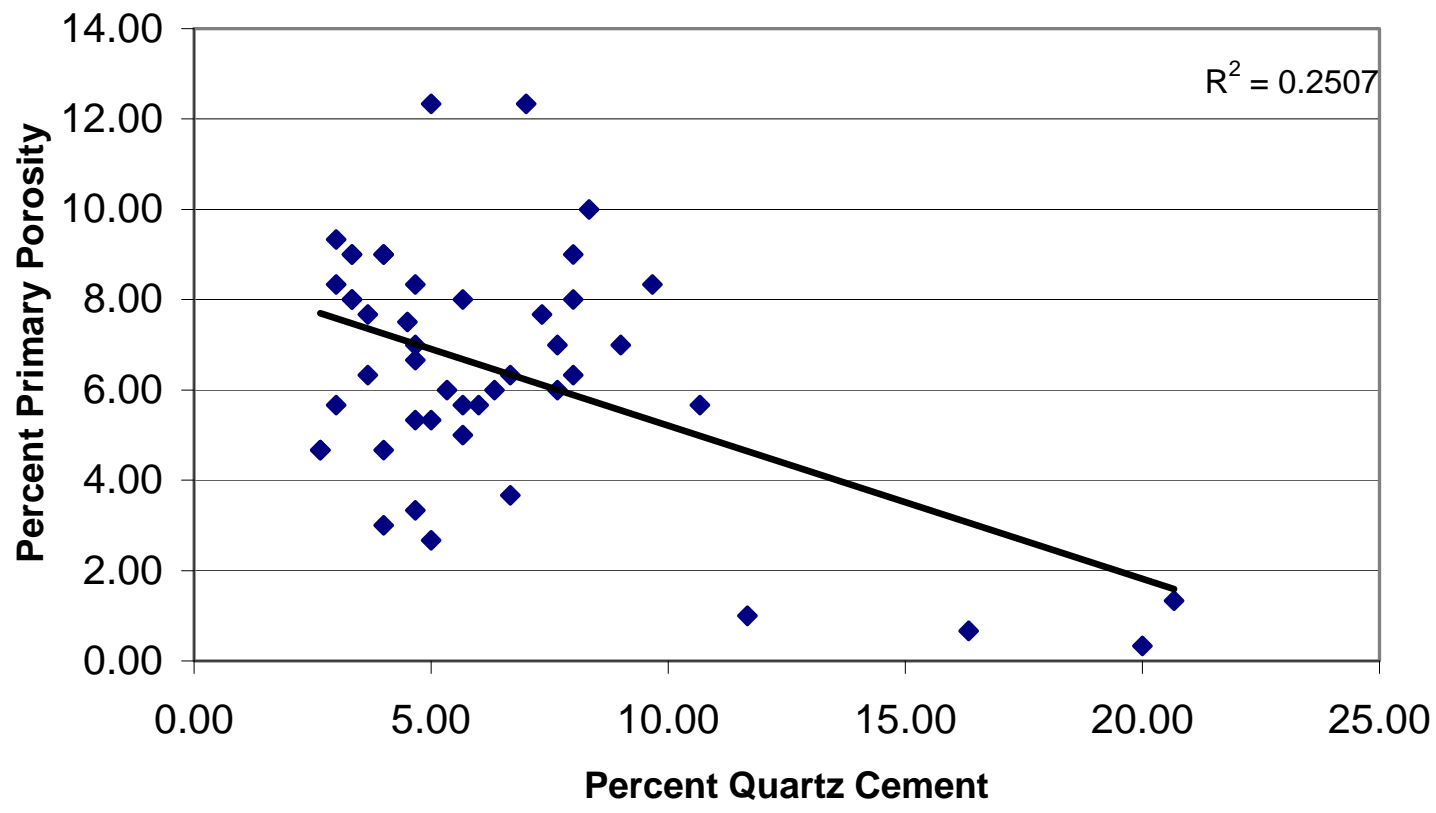


Figure 44 -- Compaction Index vs Primary Porosity

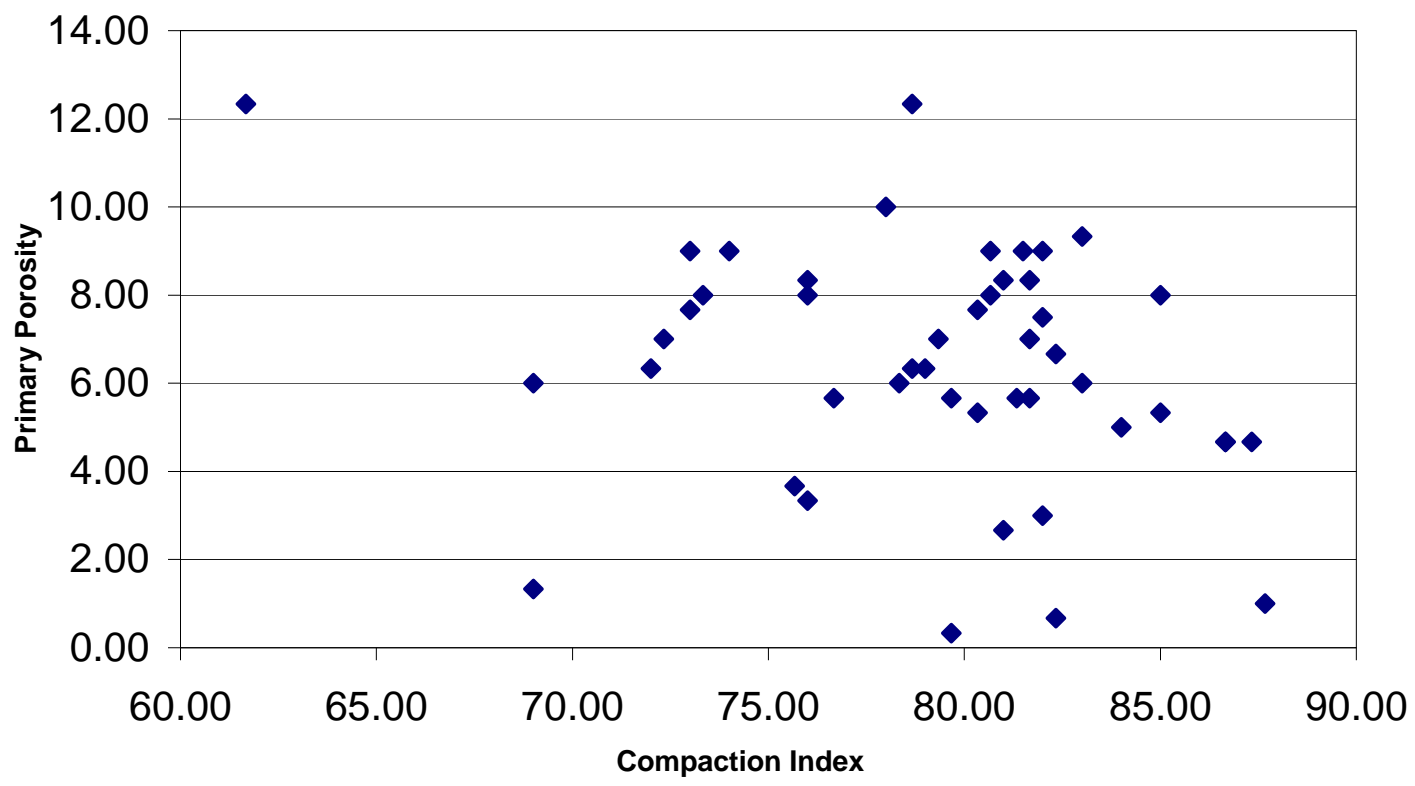

Figure 45 -- Primary Porosity Vs Chlorite Coatings

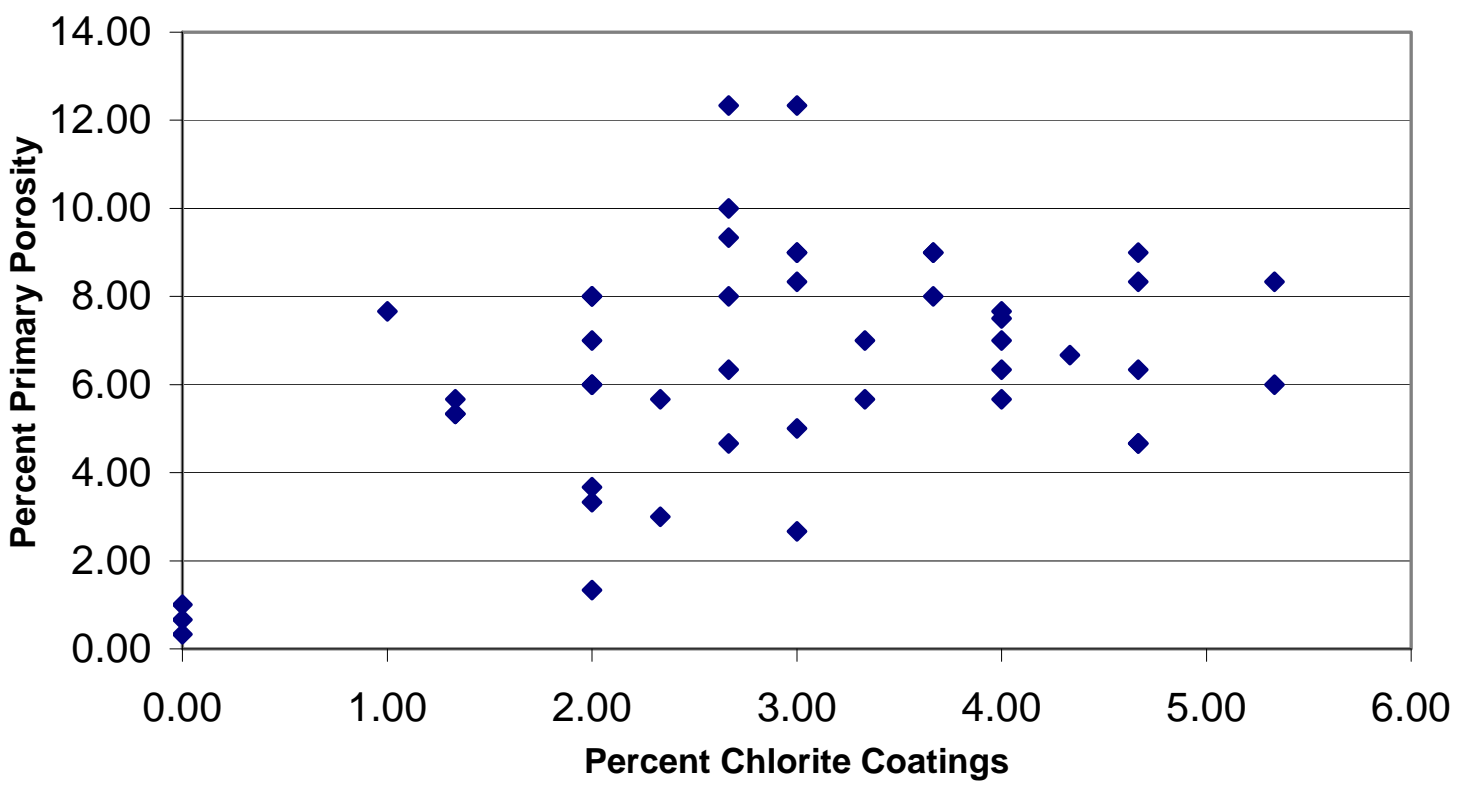


form early in diagenesis after compaction. In sample 1880 a feldspar grain has been leached leaving only remnants of feldspar and a chlorite coating (Figure 46). This shows that the chlorite coating was formed before the grain was leached and that no subsequent compaction occurred. In the sample at 1859 feet, a feldspar grain has intraparticle porosity with chlorite rims coating the inside of the pore (Figure 47). This sample shows that chlorite rims and dissolution overlapped in time.

In the Murrysville sandstone secondary porosity is present mostly as moldic pores. Moldic pores are the result of dissolution of unstable grains, where the shape or mold of the dissolved grain is preserved. In some instances the shape of the mold or remnant material left behind may provide insight into the type of grain that was dissolved. Intragranular secondary porosity, generated by partial grain solution, is also present and is most commonly present in feldspars, metamorphic rock fragments and less commonly shale rock fragments. These types of pores are known also as an intra-particle pores and are formed by post-depositional leaching (Schmidt and McDonald, 1979). Secondary porosity ranges from 0.67 percent to 11 percent, with a mean of 3.89 percent. Figure 48 shows that secondary porosity is higher in samples that had a higher concentration of phyllite grains, which suggests that the more chemically unstable lithics, more secondary porosity. In some instances the original form of the grain remains, outlined by matrix or more often chlorite rims. Some feldspars have been completely leached, some are only partially leached, whereas a few remain intact. Feldspars are commonly dissolved along twin planes. Other grains exhibit intragranular porosity in random patterns. 
Secondary porosity in the form of fractures is also present in the Murrysville. The fractures are small and have not been filled with cement. Figure 49 shows that secondary porosity decreases with depth. The average secondary porosity in the top 10 feet is 7 percent and 2 percent in the bottom 10 feet. A greater amount of secondary porosity at the top of the Murrysville can be explained by either (1) more rock fragments at the top of the Murrysville to leach or (2) leaching fluids generated in the overlying Riddlesburg Shale entered the Murrysville. A graph of total porosity can be seen in Figure 50. In Figure 51 many figures are displayed next to one along for easier comparison. The curves present include the gamma ray and density curves from the geophysical log, thin section porosity, porosity measured by BJ services (which includes microporosity) and microfacies all plotted against depth.

In the Murrysville it seems that no one factor has a great effect on permeability; instead all factors culminate to determine permeability (Pettijohn and others, 1987). Permeability measures the ability of a medium to transmit a fluid and the unit of measurement is the millidarcy. BJ Services, of Tomball, Texas, conducted permeability tests on 39 of the Murrysville samples. Permeability values ranged from 0.005 millidarcies to nearly 1000 millidarcies. Permeability is high throughout the Murrysville sandstone as seen in Figure 52. Figure 53 shows how permeability relates to porosity as measured by core analysis by BJ Services. Grain size, sorting, orientation, packing, and cementation all affect permeability (Pettijohn and others, 1987). Permeability decreases with a decrease in grain size because of increasing internal surface area, which affects fluid flow (Pettijohn and others, 1987). Better sorting of grains tends to increase permeability. Orientation and packing appear to have a weak control on permeability, 
but it has been found that permeability is greater parallel to the mean shape fabric and that tighter packing decreases permeability. Cementation has a great impact on permeability, the more cement the lower the permeability. 


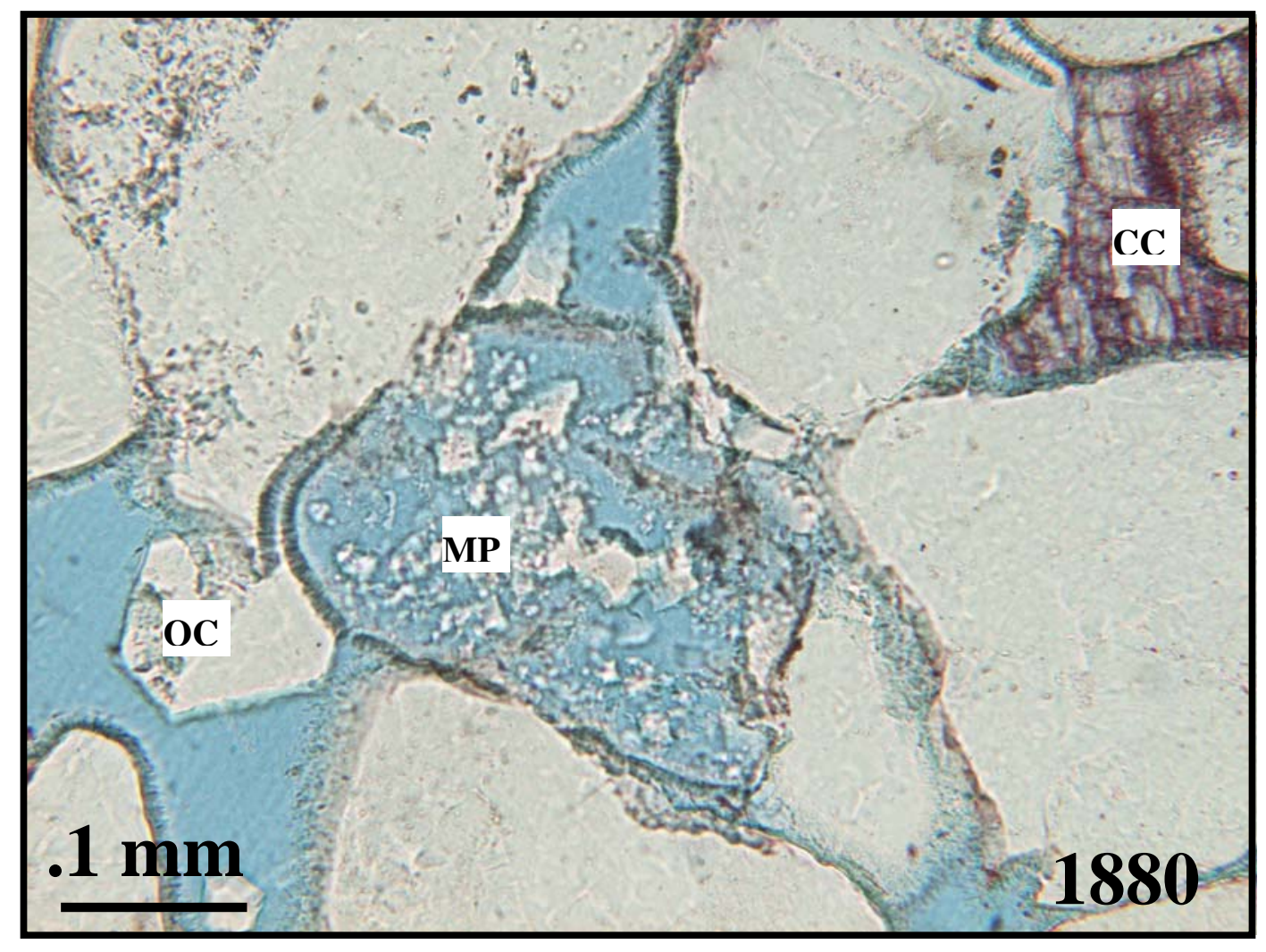

Figure 46 - Moldic pore (MP) with chlorite rims still intact. QC - quartz cement, CC - calcite cement 

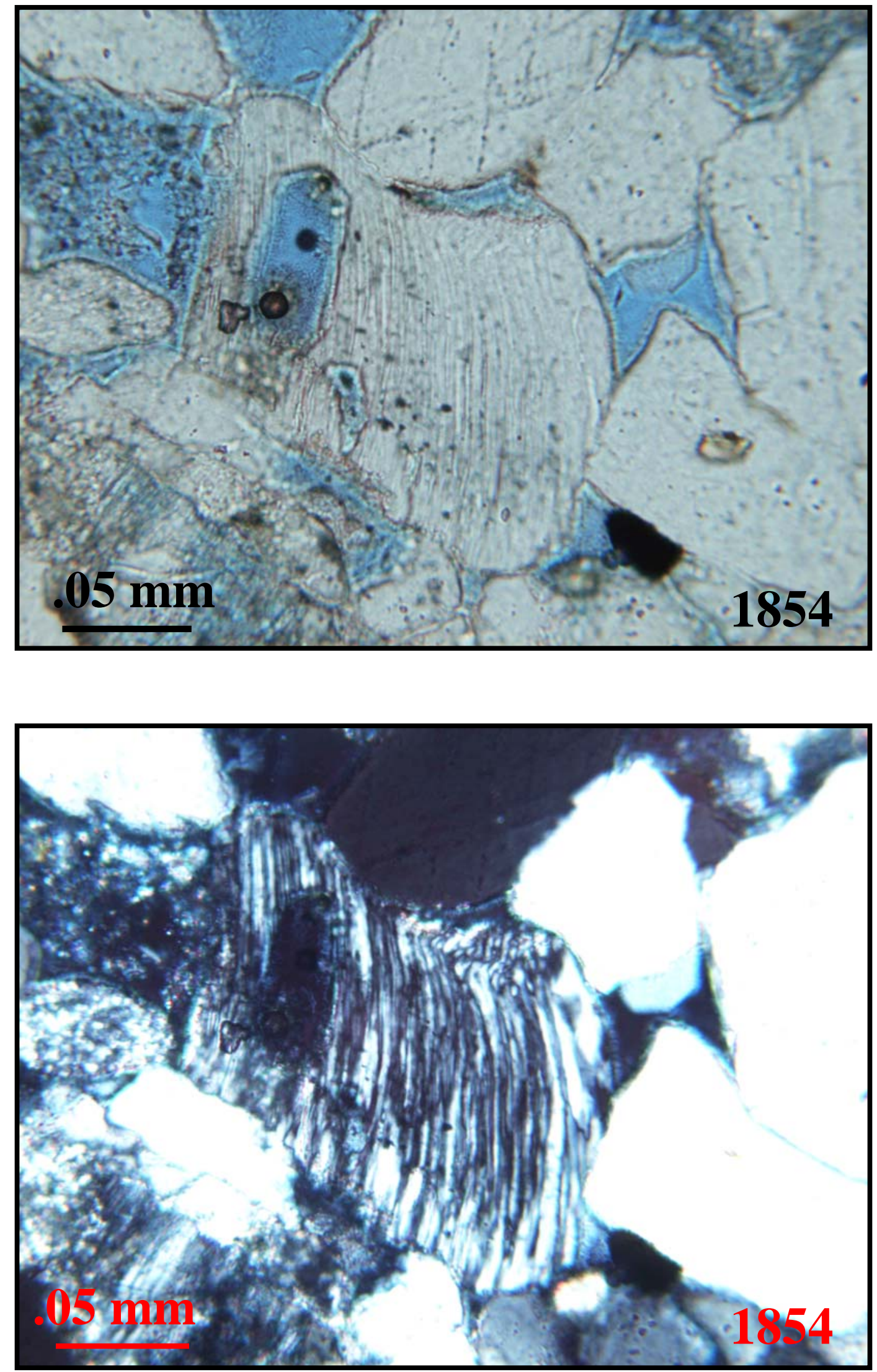

Figure 47 - Intragranular feldspar pore coated with chlorite needles in plane polarized light (top) and crossed polarized light (bottom). 
Figure 48 -- Phyllite vs. Secondary Porosity

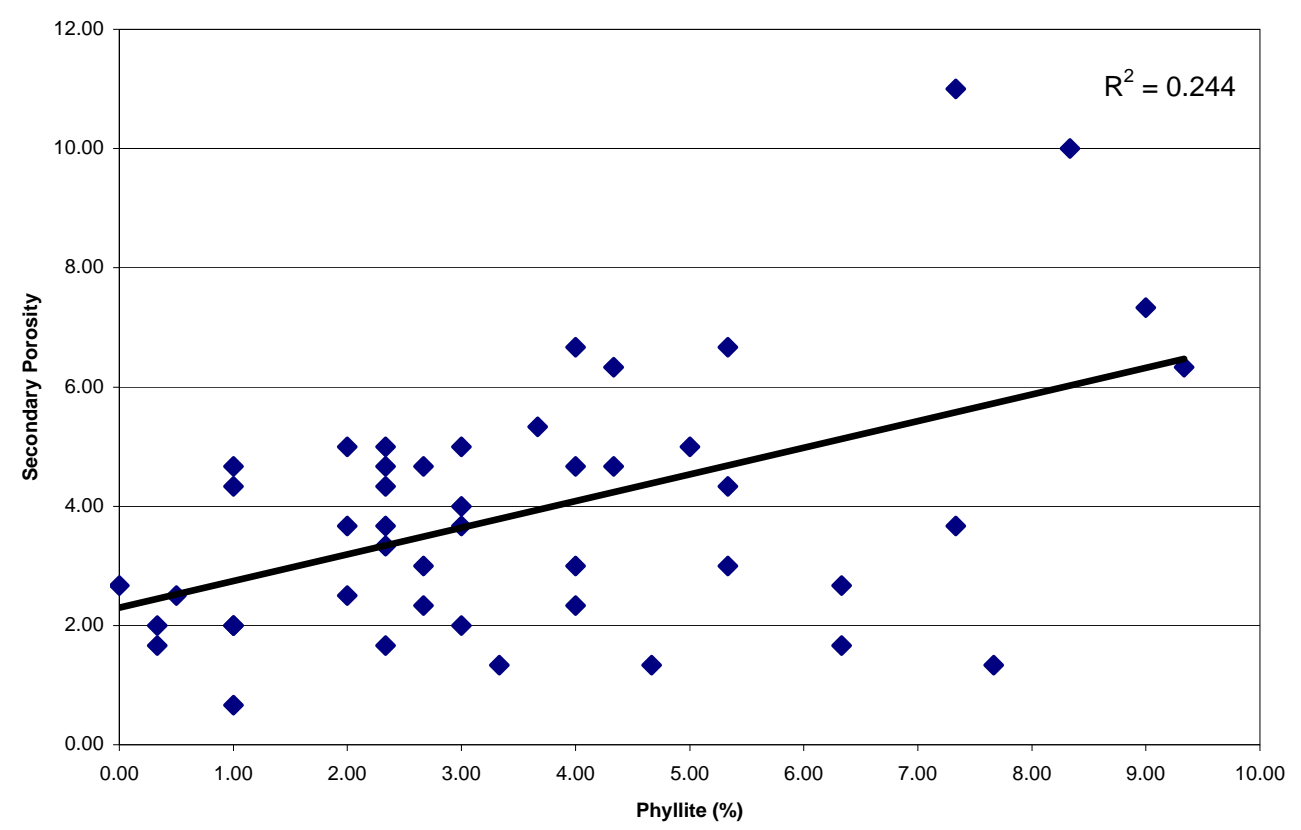

Figure 49 -- Secondary Porosity Vs Depth

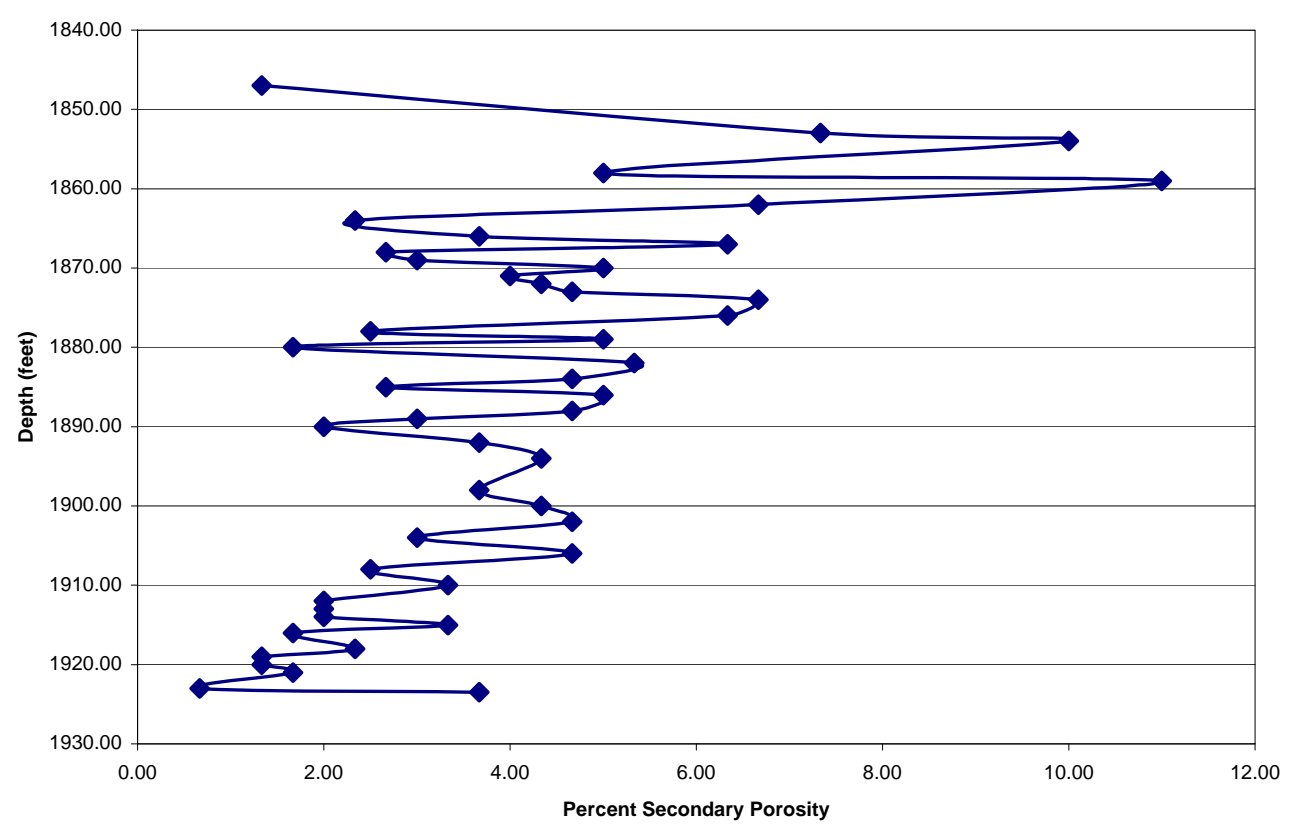




\section{Figure 50 -- Total Porosity vs Depth}

${ }^{*}$ Depth is not to scale

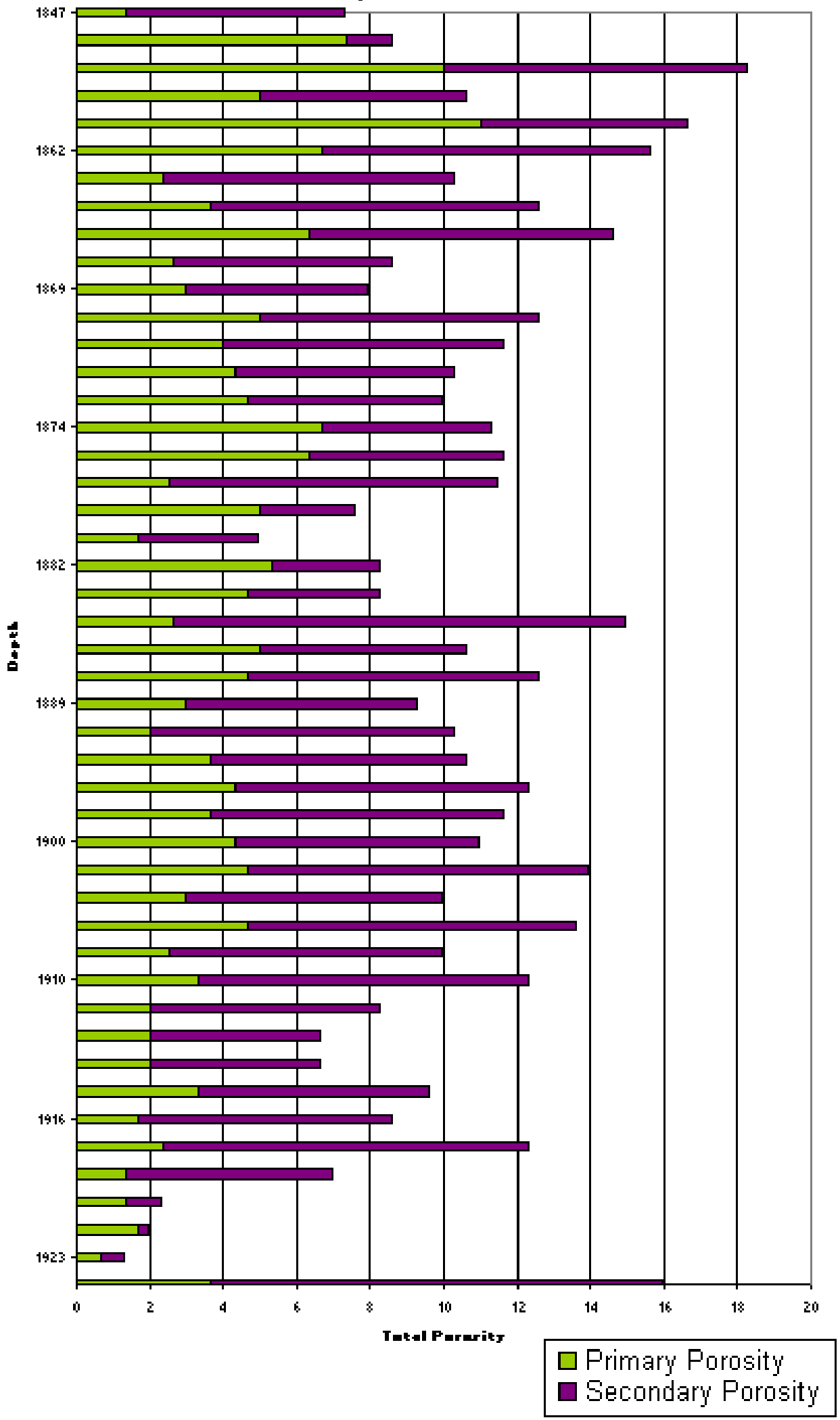



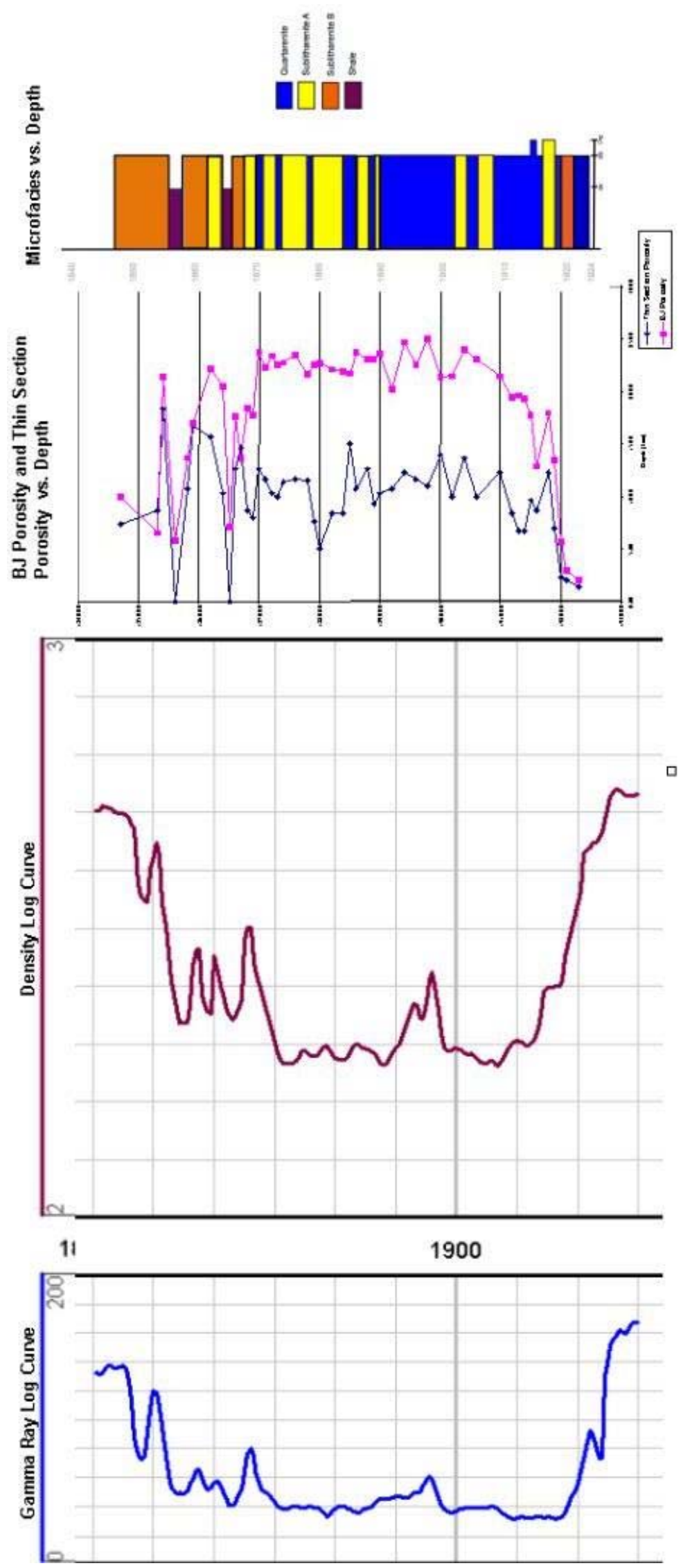

Figure 51 - Gamma ray log curve, density log curve, porosity measured by BJ Services, thin section measured porosity and microfacies are plotted versus depth. 
Figure 52 -- Permeability vs Depth

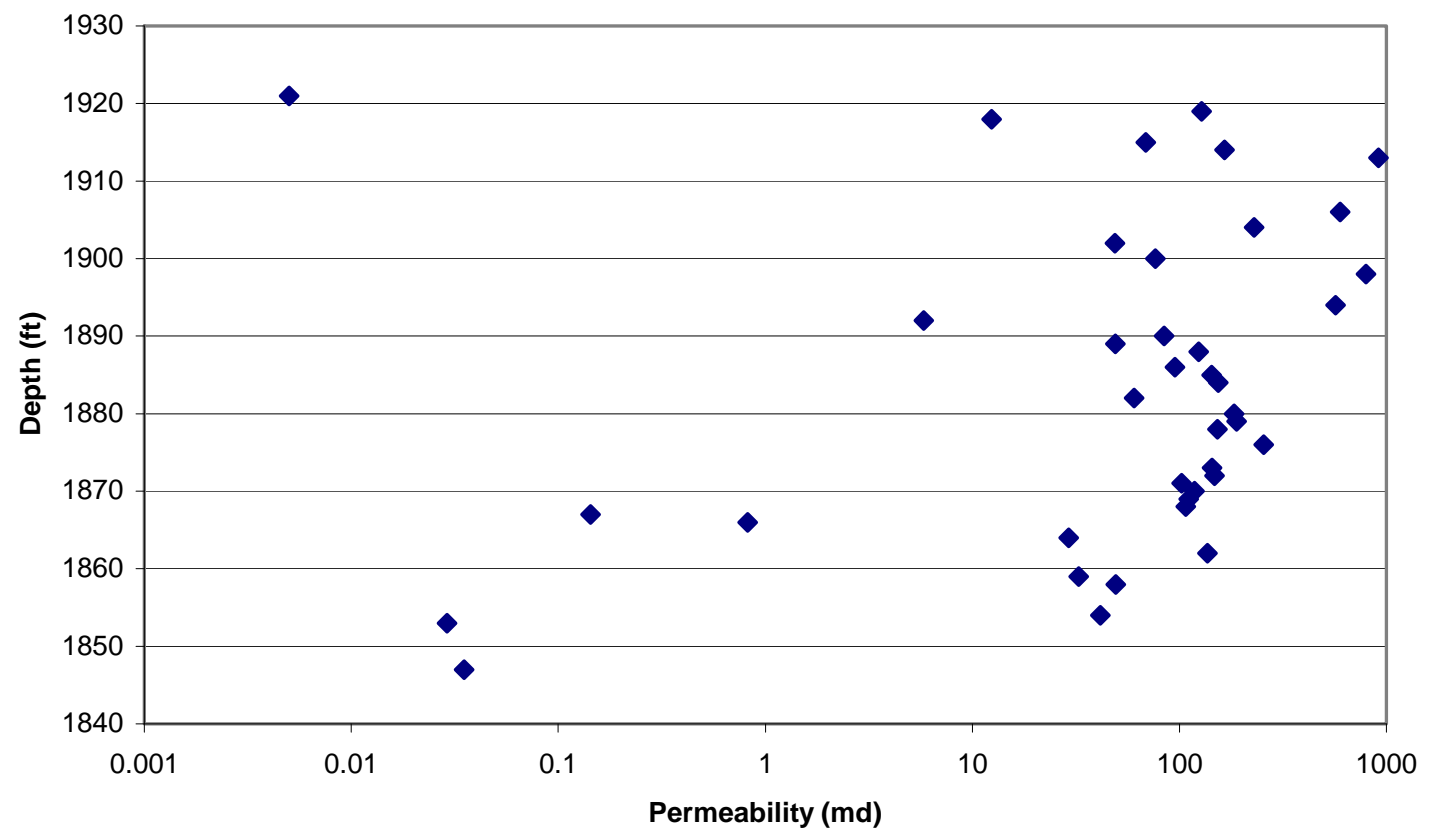

Figure 53 -- Total Porosity vs Permeability

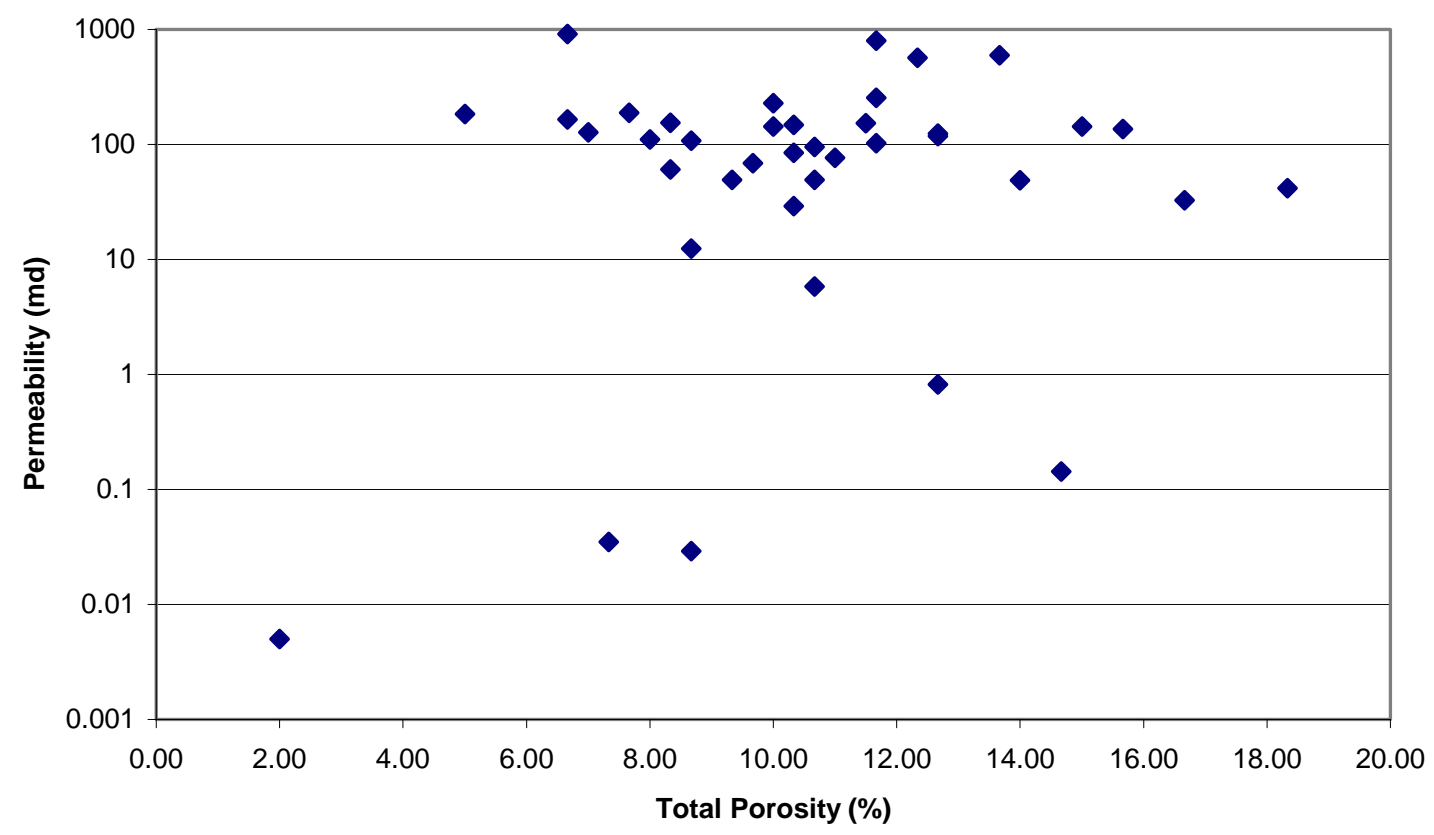




\section{CONCLUSIONS}

The Murrysville sandstone is locally recognized in southwestern Pennsylvania. The lower two-thirds of the formation is correlative to the Cussewago of northwestern Pennsylvania, whereas the upper third is equivalent to the Berea of Ohio. The Murrysville was formed in the Early Mississippian after sedimentation on the Catskill delta ceased.

Thin section analyses showed that five microfacies are present; quartzarenite, sublitharenite A, sublitharenite B, conglomerate and shale. The Cussewago equivalent, the lower two-thirds, is mostly composed of quartzarenite, and the two conglomerates are found here near the base. The Cussewago equivalent is interpreted as fluvial deltaic. Quartzarenite sand is most likely from preexisting rocks southeast of the study area. The Berea equivalent, the upper third, is composed of marine transition stream deposits as the epicontinental sea began to transgress. Quartz content decreases and percent lithic fragments increases in this section suggesting the drainage area enlarged overtime, including a more diverse bedrock, or that the energy level decreased allowing more lithics to be preserved.

In the diagenetic sequence, compaction was the first event to occur and was responsible for porosity reduction. The compaction index for the Murrysville sandstone ranges from 62 to 88 percent. The higher number represents a closer packing and greater compaction. A high percent of rigid grains and low percent of ductile grains provided stability and retarded compaction. Grain size also affected compaction in the Murrysville. As grain size increased, compaction decreased due to greater stability with 
more grain contacts. Matrix was present in many samples and occupied space between grains retarding compaction.

Chlorite rims were the first cement to occur. Chlorite rims are responsible for preserving primary porosity by inhibiting cement. Quartz cement most commonly occurs at the top and bottom of the formation where in contact with the Riddlesburg and Riceville Shales. It is believed that connate water or clay mineral transformation in the encasing shales is the source for both the chlorite and quartz cement. Calcite cement and siderite cement are also present in the Murrysville and were the last cements to form.

Secondary porosity is present as moldic and intragranular porosity. The most commonly leached grains were feldspars and rock fragments. Secondary porosity is higher in samples at the top of the formation where there is a higher concentration of phyllite grains.

Permeability values are high for the Murrysville due to many factors including interlocking porosity, and lack of extensive compaction and cementation. The Murrysville's overall standing as a reservoir and storage field also depends on many of these factors. The lack of extensive compaction, cement inhibited by chlorite rims and many other factors enhanced porosity and permeability making the Murrysville a very porous and permeable formation. 


\section{REFERENCES}

Berner, R., 1981. A New Geochemical Classification of Sedimentary Environments in Journal of Sedimentary Research, v. 51 n.2, pp 359-365.

Billault, V., D. Beaufort, A. Baronnet, and J C Lacharpagne, 2003. A nanopetrographic and textural study of grain-coating chlorites in sandstone Reservoirs, in Clay Minerals (2003) 38, 315-328.

Bjerstedt, T.W. and T.W. Kammer, 1988. Genetic stratigraphy and depositional systems of the Upper Devonian-Lower Mississippian Price-Rockwell Deltaic complex in the central Appalachians, U.S.A. Sedimentary Geology, v. 54, p. 265-301.

Bjorlykke, K., 1984. Formation of secondary porosity: how important is it? in McDonald, D.A., Surdam, R.C. (Eds.), Clastic Diagenesis. AAPG Memoir, vol. 37, p. 277- 286.

Blatt, H., 1992. Sedimentary Petrology: New York, W.H. Freeman, p. 514.

Bloch S. Effect of detrital mineral composition on reservoir quality. In: Wilson MD, editor. Reservoir quality assessment and prediction in clastic rocks. SEPM Short Course, vol. 30. 1994. p. 161-82.

Bloch S, McGowen JH. Influence of depositional environment on reservoir quality prediction. In: Wilson MD, editor. Reservoir quality assessment and prediction in clastic rocks. SEPM Short Course, vol. 30. 1994. p. 41-57.

Boswell R.M. and A.C. Donaldson, 1988. Depositional Architecture of the Upper Devonian Catskill Delta Complex: Central Appalachian Basin, U.S.A. in Devonian of the World, p. 65-84.

Boswell, R.M., L.R. Heim, G.R. Wrightstone, and A. Donaldson, 1996. Play Dvs: Upper Devonian Venango sandstones and siltstones, in The Atlas of Major Appalachian Gas Plays. J.B. Roen and B.J. Walker, eds. West Virginia Geological and Economic Survey, Pub. V-25, p. 63-76.

Cant, D.J. 1982. Fluvial facies models and their application in Scholle, P. A., and Spearing, D. R., eds., Sandstone depositional environments, 31 of AAPG Memoirs: Tulsa, OK, AAPG, p. 115-137.

Carter, J.L. and T.W. Kammer, 1988. Late Devonian and Early Carboniferous brachiopods (Brachiopoda, Articulata) from the Price Formation of West Virginia and adjacent areas of Pennsylvania and Maryland. Annals of Carnegie Museum, v. 59, no. 2, p. 77-103. 
Coleman, J.M. and D.B. Prior, 1981. Deltaic environments. In Woodward, Howell, Beaumont, Hart, and White (eds.) Sandstone Depositional Environments.

American Association of Petroleum Geologists, Memoir, 31. pp. 139-178.

Colton, G.W. (1970), The Appalachian Basin - its depositional sequences and their geologic relationships, p. 5-48 in Fisher, G.W., and others, eds., Studies of Appalachian Geology: Central and Southern, Interscience Publishers, New York, p. 460.

Coogan, A. H. (1970), Measurements of Compaction in Oolitic Grainstone, in Journal of Sedimentary Petrology, v. 40, no. 3, p. 921-929.

de Witt, W., Jr. 1946. The stratigraphic relationship of the Berea, Corry, and Cussewago sandstones in northeastern Ohio and northwestern Pennsylvania. U.S. Geological Survey Oil and Gas Investigations, Preliminary Chart 21.

--- 1970. Age of the Bedford Shale, Berea Sandstone, and Sunbury Shale in the Appalachian and Michigan Basins, Pennsylvania, Ohio, and Michigan. U.S. Geological Survey Bulletin 1924-G, p. 11.

Dickinson, W.R., and Suczuk, C.A.(1979), Plate tectonics and sandstone compositions: American Association of Petroleum Geologists Bulletin, v. 63, p. 2164-2182.

Edmunds, W.E., Berg, T.M., Sevon, W.D., and others (1979), The Mississipian and Pennsylvania (Carboniferous) systems in the United States - Pennsylvania and New York: U.S. Geological Survey Professional Paper 1110-B, p. B1-B33.

Ehrenberg, S. N., 1993, Preservation of anomalously high porosity in deeply buried sandstones by grain-coating chlorite: examples from the Norwegian continental shelf: AAPG Bulletin, v. 77, p. 1260-1286.

Ettensohn, F.R. 1985. "Controls on development of Catskill Delta complex basin-facies." pp. 65-77. In: D.L. Woodrow and W.D. Sevon (eds.). The Catskill Delta. Geological Soc. America Special Paper 201.

Folk, R.L., 1968. Petrology of sedimentary rocks. Hemphill Publishing Company, Austin, TX., p. 170.

Fuchtbauer, H., 1983, Facies control on sandstone diagenesis, in Parder and Selwood, eds., Sandstone Diagenesis: Reider Publishing, p. 269-288.

Harper, J.A. and C.D. Laughrey, 1987, Geology of the oil and gas fields of southwestern Pennsylvania, Pennsylvania Bureau of Topographic and Geologic Survey, Mineral Resources Rep. M87, p. 166.

--- 1989. Upper Devonian and Lower Mississippian stratigraphy and depositional systems, in Geology in the Laurel Highlands of Southwestern Pennsylvania, J.A. Harper 
ed., 54th Annual Field Conference of Pennsylvania Geologists Guidebook, Oct. 5,6, and 7, 1989, p. 191-202.

Heald, M. T., and R. E. Larese, 1974, Influence of coatings on quartz cementation: Journal of Sedimentary Petrology, v. 44, p. 1269-1274.

Helmold, K.P. and van de Kamp, P.C. (1984) Diagenetic mineralogy and controls on albitization and laumontite formation in Paleogene arkoses, Santa Ynez Mountains, California. American Association of Petroleum Geologists Memoir, 37, 239-276.

Johnsson, M.J., R.F. Stallard, and R.E. Meade, 1988, First cycle arenites in the Orinoco River basin, Venezuela and Colombia: Journal of Geology, v. 96, p. 263-277.

Kammer, T.W. and T.W. Bjerstedt, 1986. Stratigraphic framework of the Price Formation (Upper Devonian-Lower Mississippian) in West Virginia. Southeastern Geology, v. 27, no. 1, p. 13-33.

Laird, W.M., 1941. The stratigraphy of the Upper Devonian and Lower Mississippian In southwestern Pennsylvania. Pa. Topogr. Geol. Surv. Prog. Rep., 126: p. 23.

McDaniel, B.A., 2006. Subsurface stratigraphy and depositional controls on Late Devonian-Early Mississippian sediments in southwestern Pennsylvania, p. 84.

Matsumoto, R., and Iijima, A, 1981. Origin and diagenetic evolution of Ca-Mg-Fe carbonates in some coalfields of Japan, Sedimentology, 28:239-259.

Newberry, J.S., 1870. Report on the progress of the Geological Survey of Ohio in 1869. Ohio Division of Geological Surv., p. 176.

Pashin, J.C. and F.R. Ettensohn, 1995. Reevaluation of the Bedford-Berea sequence in Ohio and adjacent states: forced regression in a foreland basin. GSA Special Paper 298, p. 68.

Pepper, J.F., W. de Witt, Jr., and D.F. Demarest, 1954. Geology of the Bedford Shale And Berea Sandstone in the Appalachian Basin. U.S. Geol. Surv., Prof. Pap. 259, p. 109.

Pettijohn, F. J. (1975). Sedimentary rocks. United States (USA): Harper \& Row, Publ., New York, N.Y., United States (USA), p. 628.

Pettijohn, F. J., Potter, P. E., \& Siever, R. (1987). Sand and sandstone. United States (USA): Springer-Verlag, New York, NY, United States (USA), p.553.

Rittenhouse G., 1971. Pore space reduction by solution and segmentation: AAPG Bulletin, V. 55, pp. 80-91. 
Schmidt, V., and McDonald, D.A., 1979. The role of secondary porosity in the course of sandstone diagenesis, Soc. of Econ. Paleontologists and Mineralogists Spec. Publication No. 26, p. 175-207.

Sevon W.D., 1985. Nonmarine facies of the Middle and Late Devonian Catskill coastal alluvial plain in Geological Society of America Special Paper 201, p. 79-90.

Shanmugam, G., 1990, Porosity prediction in sandstones using erosional unconformities, in I.D. Meshri and P.J. Ortoleva, eds., Prediction of reservoir quality through chemical modeling: AAPG Memoir 49, p. 1-23.

Smosna, R., 1989. Compaction law for Cretaceous sandstones of Alaska's North Slope Journal of Sedimentary Research, V. 59: 572-584.

Smosna, R. and K.R. Bruner, 1997. Depositional controls over porosity development in lithic sandstones of the Appalachian Basin: reducing exploration risk. AAPG Memoir, 69:249-265.

Stonecipher, S.A., 2000. Applied Sandstone Diagenesis-Practical Petrographic Solutions for a Variety of Common Exploration, Development and Production Problems: SEPM Short Course Notes, No. 50.

Surdam, R.C., Boese, S.W., and Crossey, L.J., 1984. The chemistry of secondary porosity, in McDonald, D.A., and Surdam, R.C., eds., Clastic Diagenesis: AAPG Memoir 37, p. 127-149.

Suttner, L.J., A. Basu, G.H., Mack, 1981, Climate and the origin of quartz arenites: Journal of Sedimentary Petrology, v. 51, p. 1235-1246.

Tomastik, T.E., 1996, Play Mde: Lower Mississippian-Upper Devonian Berea and equivalent sandstones, in The Atlas of Major Appalachian Gas Plays, J.B. Roen and B.J. Walker, eds., West Virginia Geological and Economic Survey, Pub. V-25, p. 56-62.

Towe, K., 1962, Clay mineral diagenesis as a possible source of silica cement in sedimentary rocks, Journal of Sedimentary Research, v. 32, n. 1, p 26-28.

Trurnit, P., 1968, Pressure solution phenomena in detrital rocks: Sedimentary Geology, v. 2, p. 89-114.

Tucker, M.E., 1981. Sedimentary Petrology: An introduction to the origin of sedimentary rocks, Blackwell Scientific Publications, p.260.

Vargo, A.G., Matchen, D.L., 1996. Play Mbi: Lower Mississippian Big Injun sandstones. In: Roen, J.B., Walker, B.J. (Eds.), The Atlas of Major Appalachian Gas Plays. West Virginia Geological and Economic Survey Publication, vol. V-25, p. 41-45. 
Wilson, M. D. and Stanton, P. T., 1994, Diagenetic mechanisms of porosity and permeability reduction and enhancement in Reservoir quality assessment and prediction in clastic rocks, SEPM Short Course notes \# 30, p. 59-117.

White, I.C., 1881. The geology of Erie and Crawford Counties. Pennsylvania Bureau of Topographic and Economic Survey, Second Series, Report XXI, p. 94-96.

Worden, R H; Mayall, M; Evans, I J, The effect of ductile-lithic sand grains and quartz cement on porosity and permeability in Oligocene and lower Miocene clastics, South China Sea; prediction of reservoir quality, AAPG Bulletin, vol. 84, no. 3, p. 345-359, Mar 2000. 
APPENDIX - Point Count Data 


\begin{tabular}{|c|c|}
\hline \multicolumn{2}{|l|}{ KEY } \\
\hline MCQ & Monocrystalline Quartz \\
\hline$\underline{\mathbf{U O}}$ & Undulose Quartz \\
\hline Cht & Chert \\
\hline PCQ & Polycrystalline Quartz \\
\hline$\underline{\underline{E Q}}$ & Elongated Polycrystalline Quartz \\
\hline MO & Metamorphic Quartz w/ Mica \\
\hline Illite & Illite Rock Fragments \\
\hline Plny & Phyllite Rock Fragments \\
\hline Met & High Grade Metamorphics \\
\hline$\overline{\mathrm{Py}}$ & Pyrite \\
\hline AMtin & $\begin{array}{l}\text { Accessory Minerals (Zircon, Chamosite, } \\
\text { Tourmaline, Leucoxene) }\end{array}$ \\
\hline Mica & Micas \\
\hline Feld & Feldspars (Plagioclase and Potassium) \\
\hline Bit & Bitumen \\
\hline ChIR & Chlorite Rims \\
\hline Silt & Silt Matrix \\
\hline Clay & Clay Matrix \\
\hline$\underline{\mathrm{QC}}$ & Quartz Cement \\
\hline$\underline{\mathrm{CC}}$ & Calcite Cement \\
\hline$\underline{\underline{S C}}$ & Siderite Cement \\
\hline Int P & Intergranular Porosity \\
\hline Hid P & Moldic Porosity \\
\hline$\underline{\text { MIP }}$ & Intragranular Porosity (Metamorphic) \\
\hline$\overline{\mathrm{QIP}}$ & Intragranular Porosity (Quartz) \\
\hline$\underline{\underline{F P}}$ & Intragranular Porosity (Feldspar) \\
\hline$\overline{\text { SIP }}$ & Intragranular Porosity (Shale) \\
\hline UIP & Intragranular Porosity (Unidentifable) \\
\hline$\underline{\mathrm{FP}}$ & Fracture Porosity \\
\hline
\end{tabular}




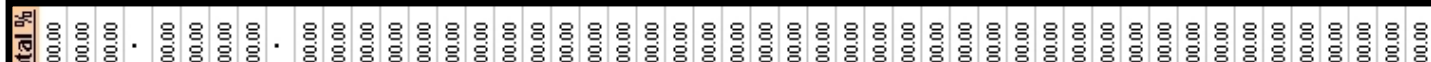

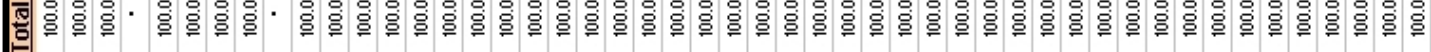

회영영

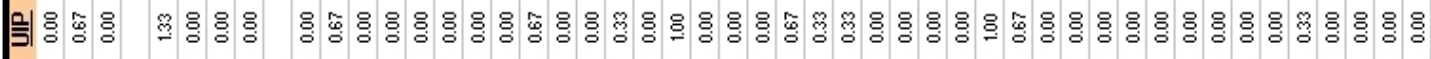

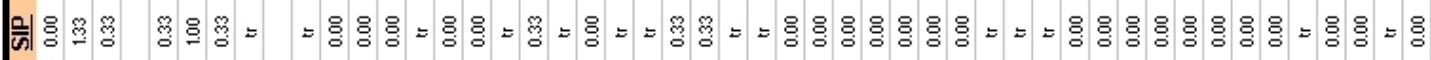

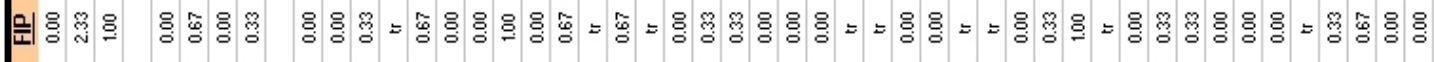

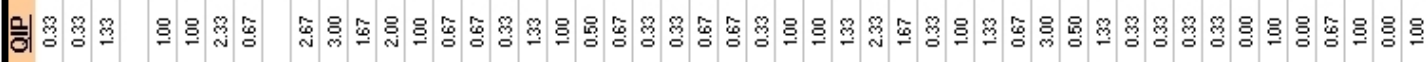

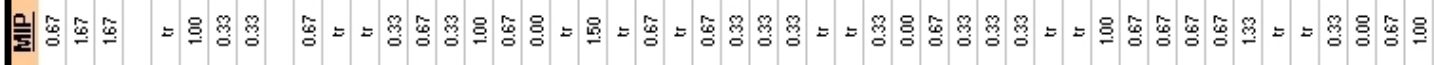

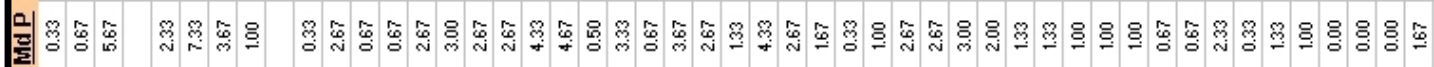

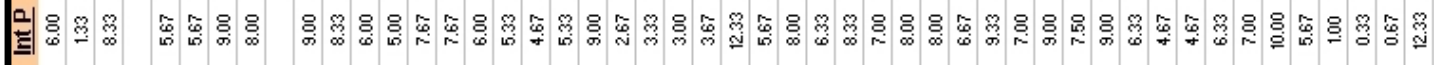

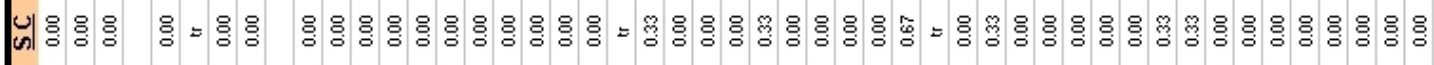

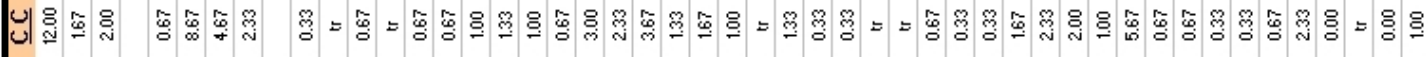

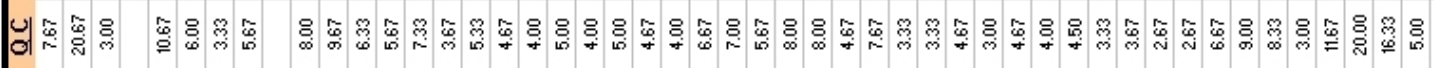

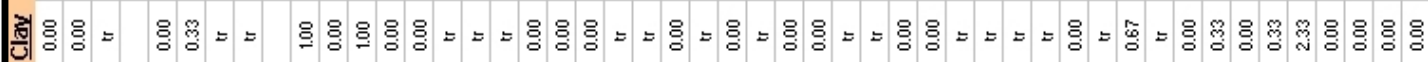

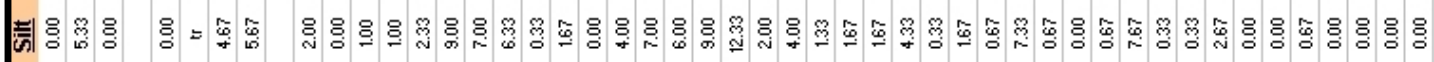

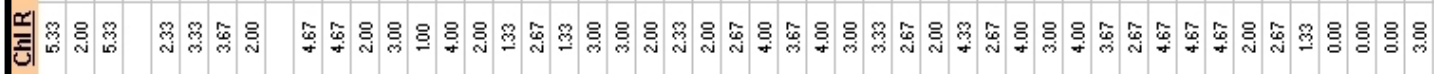

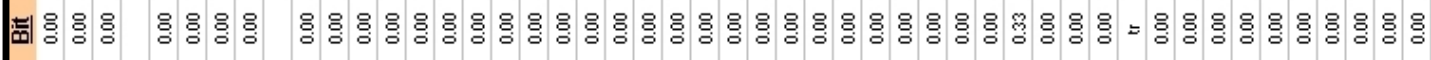

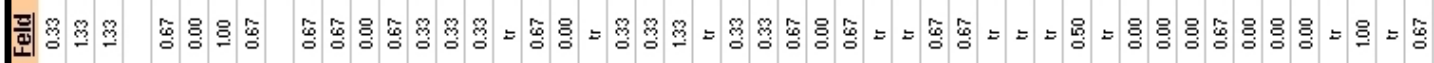

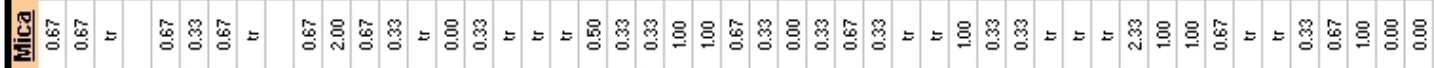

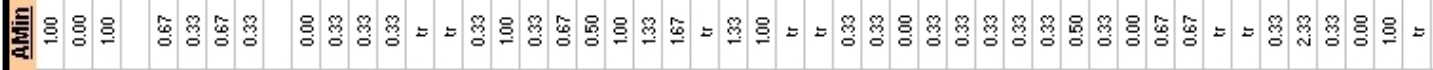

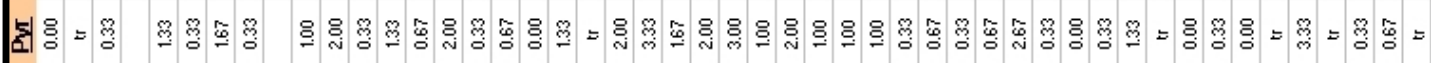

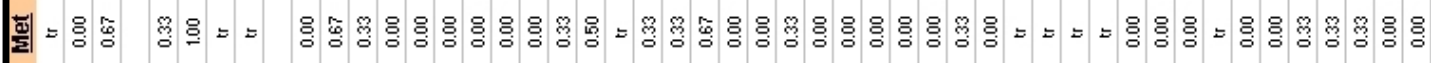

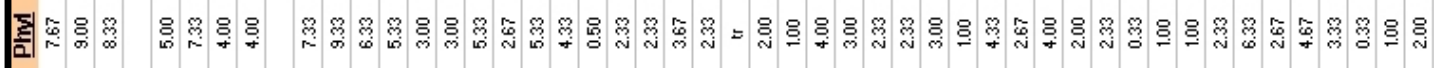

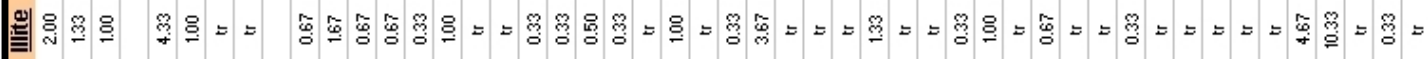

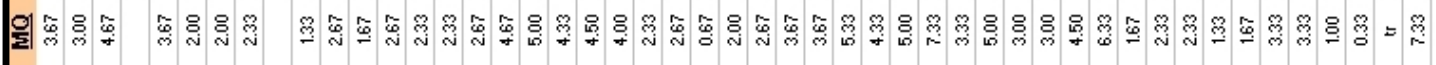

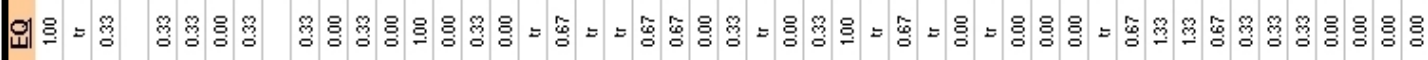

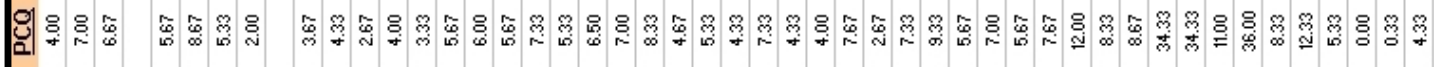

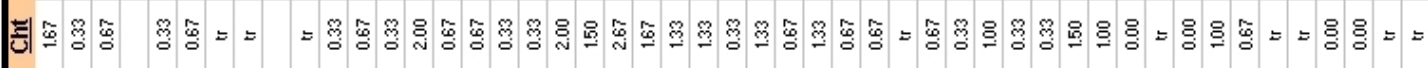

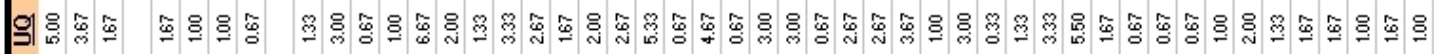

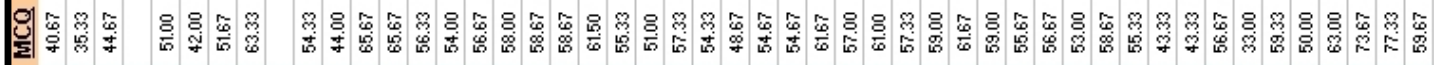

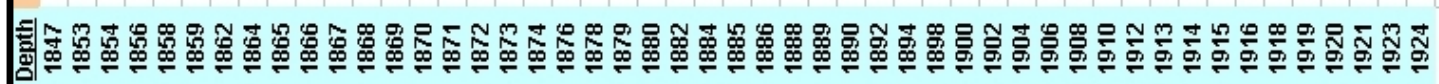

